\title{
Preliminary Amphibian and Reptile Survey of the Lewis and Clark National Forest: 1994
}

\author{
A Report to: \\ USDA Forest Service \\ Lewis and Clark National Forest \\ 1101 15th Street N. \\ Box 869 \\ Great Falls, MT 59403
}

Submitted by

JAMES D. REICHEL

March 1995

Montana Natural Heritage Program

1515 East Sixth Avenue

P.O. Box 201800

Helena, MT 59620-1800 


\section{(C) 1995 Montana Natural Heritage Program}

This document should be cited as follows:

Reichel, J. D. 1995. Preliminary amphibian and reptile survey of the Lewis and Clark National Forest: 1994. Montana Natural Heritage Program. Helena, MT. 92 pp. 


\begin{abstract}
A total of 40 surveys and several additional sightings were made in the Lewis and Clark National Forest (L\&CNF) between May and September 1994. Most were surveys of ponds, lakes, seeps, streams or other wetlands, made by 1 or 2 individuals. Each survey took 10-200 person-minutes and consisted of a thorough search of the wetland perimeter and netting of near shore aquatic habitats for adults, eggs, larvae, and tadpoles. Stream sampling was done by hand and dipnet. Seeps were checked by rolling over rocks and logs in and near wet areas. In addition to surveys, sightings were made from road kills, vocal identifications or fortuitous sightings by other reliable individuals.

Localized areas across the entire forest were covered in the survey, with specific locations determined largely by priorities set by Mike Enk, Fisheries Biologist for the Lewis and Clark National Forest.

Six amphibians are reported from the L\&CNF: Long-toed Salamander (Ambystoma macrodactylum), Tailed Frog (Ascaphus truei), Western Toad (Bufo boreas), Northern Chorus Frog (Pseudacris triseriata), Northern Leopard Frog (Rana pipiens), and Spotted Frog (Rana pretiosa). The Spotted Frog was the most widespread amphibian throughout the forest. The Tailed Frog and Long-toed Salamander were found in a few locations on the Rocky Mountain Ranger District (RMRD). The Western Toad was found in very small numbers on the RMRD in 1994. Historically it has also been reported in the Highwood, Little Belt, and Crazy Mountains; however it was not found during our surveys. Given the apparent region-wide declines in this species, all sightings should be reported. The Northern Leopard Frog was reported historically from a single site on the RMRD and several sites in the Highwood Mountains on the L\&CNF; none were found on the L\&CNF in this survey. It also has been reported historically from numerous prairie ponds, outside and at lower elevations than L\&CNF lands. Northern Leopard Frogs are nearly extirpated from western Montana, and anecdotal evidence indicates a decline elsewhere in Montana (except the southeast corner); all sightings should be reported. The Northern Chorus Frog was common in prairie ponds, primarily outside and lower in elevation than L\&CNF lands. Four other prairie-inhabiting amphibians have been recorded in the area, though in some cases well away from L\&CNF lands; these include the Tiger Salamander (Ambystoma tigrinum), Great Plains Toad (Bufo cognatus), Woodhouseís Toad (Bufo woodhousii), and Plains Spadefoot (Scaphiopus bombifrons).

Eleven reptiles have been reported from near the L\&CNF, but only two have been definitely reported from on the forest: the Western Terrestrial Garter Snake (Thamnophis elegans) and Common Garter Snake (Thamnophis sirtalis). Both were found in the RMRD and Little Belt Mountains. The Western Terrestrial Garter Snake also was found in the Big Snowy Mountains and there is a specimen record of the Common Garter Snake from the Highwood Mountains. The Rubber Boa (Charina bottae) and Racer (Coluber constrictor) have been recorded on the Helena NF just to the south and west of the L\&CNF and therefore are likely to be found on the L\&CNF as well. The Spiny Softshell (Trionyx spinifera) is present in large rivers at lower elevations; records include the Musselshell River near Shawmut and perhaps Canyon Ferry Reservoir. This species could also occur on the Smith or Judith Rivers. The following reptiles have been recorded in the area and may eventually be found on
\end{abstract}


lower elevation L\&CNF lands: Painted Turtle (Chrysemys picta), Short-horned Lizard (Phrynosoma douglasi), Western Hognose Snake (Heterodon nasicus), Gopher Snake (Pituophis catenifer), Plains Garter Snake (Thamnophis radix), and Western Rattlesnake (Crotalus viridis). 


\section{TABLE OF CONTENTS}

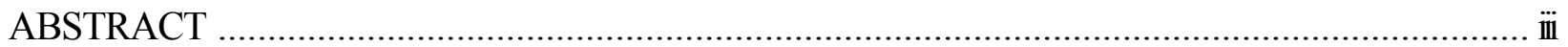

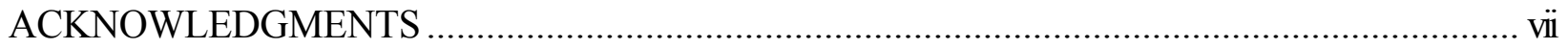

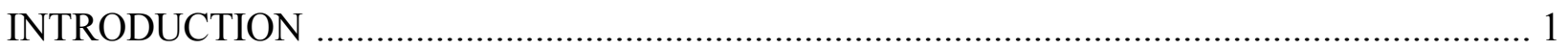

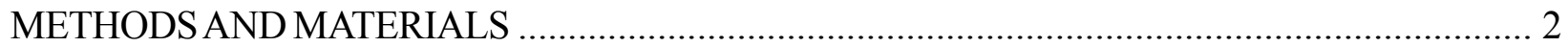

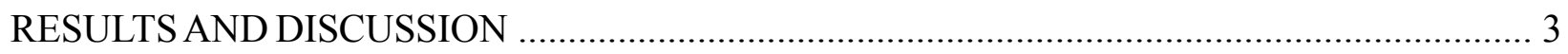

Species known to be present on the Lewis and Clark National Forest ..................................... 6

Long-toed Salamander (Ambystoma macrodactylum) .................................................... 6

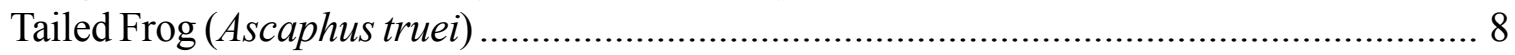

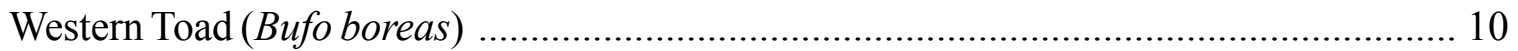

Western Chorus Frog (Pseudacris triseriata) ............................................................ 12

Northern Leopard Frog (Rana pipiens) ............................................................... 14

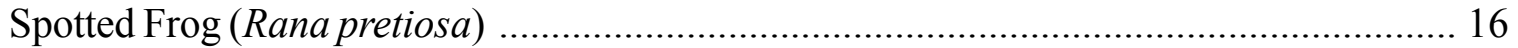

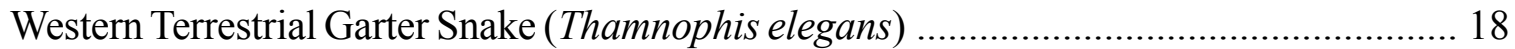

Common Garter Snake (Thamnophis sirtalis) ............................................................... 20

Species Potentially Present on the Lewis and Clark National Forest ..................................... 22

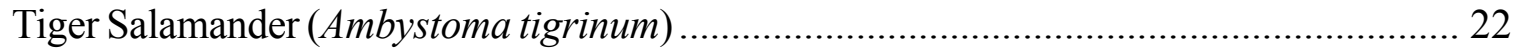

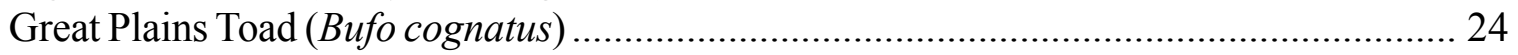

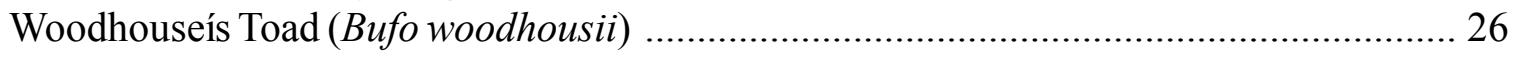

Plains Spadefoot (Scaphiopus [=Spea] bombifrons) ................................................. 28

Painted Turtle (Chrysemys picta) ........................................................................ 30

Spiny Softshell (Trionyx spiniferus) (=Apalone spinifera) ............................................. 32

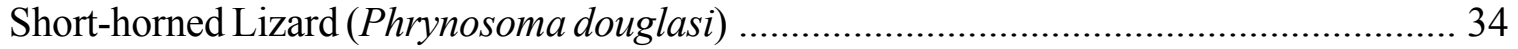

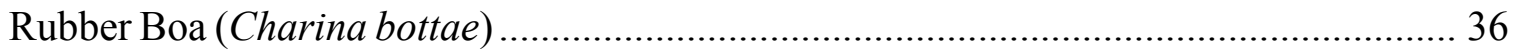

Racer (Coluber constrictor) ................................................................................ 38

Western Hognose Snake (Heterodon nasicus) ............................................................... 40

Gopher Snake (Pituophis catenifer [=melanoleucus]) ............................................... 42

Plains Garter Snake (Thamnophis radix) ................................................................. 44

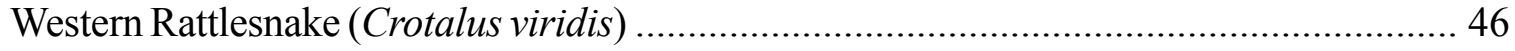

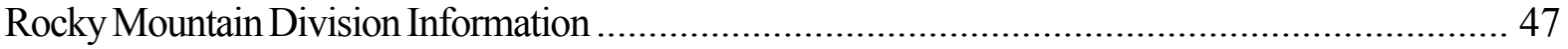

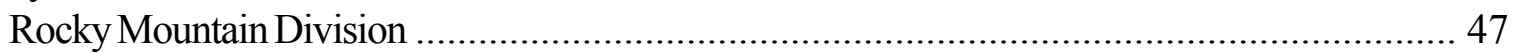

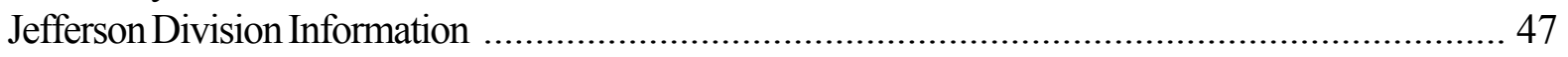

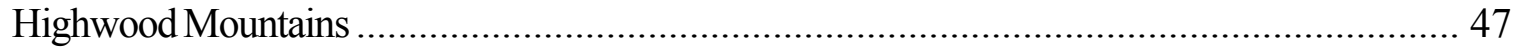

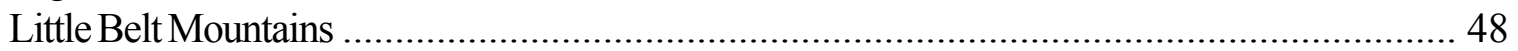

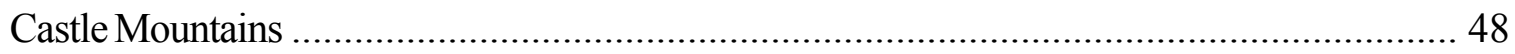

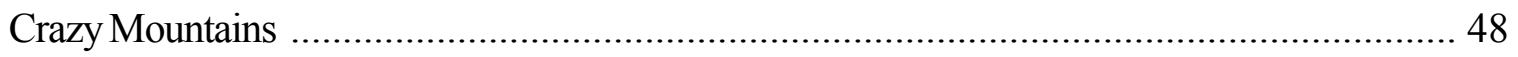

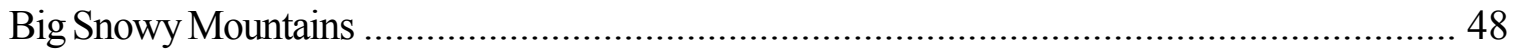

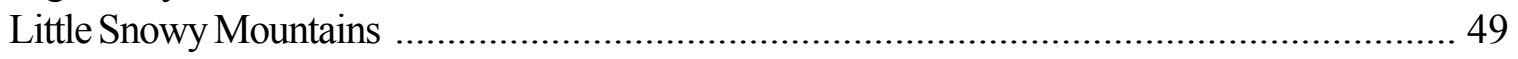




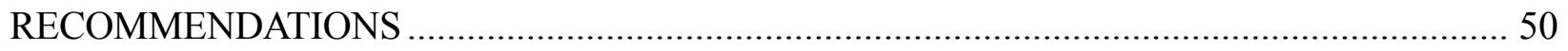

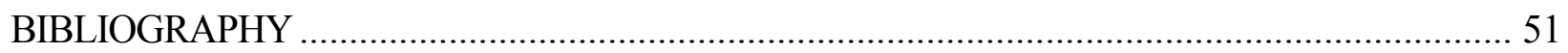

Appendix 1. Data Sheets used for Reptiles and Amphibian Surveys and Observations .................. 65

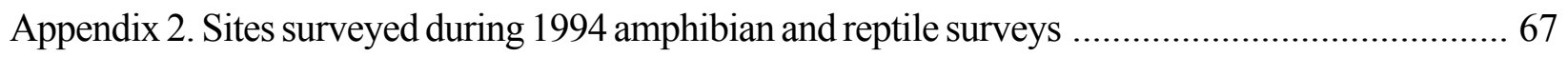

Appendix 3. Amphibians and reptiles observed during surveys of the Lewis and Clark National

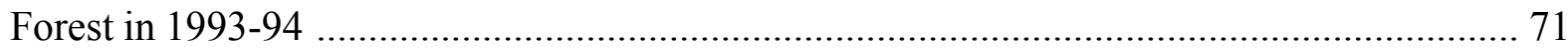

Appendix 4. Amphibians and reptiles reported from in and around the Lewis and Clark National Forest 


\section{ACKNOWLEDGMENTS}

We thank Mike Enk for his help throughout the study. Additional help, location of possible survey sites, information on herp observations, and other support was provided by Seth Diamond, Portia Jelinek, Dave Pilliod, Phillip Whitechey, Tom Whitford, and other Forest Service personnel. D. D. Dover, C. Jones, K. Jurist, and S. Thweatt assisted with element occurrence and map preparation. Financial support for the project came from the Lewis and Clark National Forest (U.S. Forest Service, Northern Region) and the Montana Natural Heritage Program (Montana State Library, Natural Resources Information System and The Nature Conservancy).

Museum records were received from: American Museum of Natural History, Academy of Natural Science, Brigham Young University, California Academy of Science, Carnegie Museum, University of Puget Sound Museum, Field Museum of Natural History, Glacier National Park Museum, Illinois Natural History Survey, University of Kansas, Los Angeles County Museum, Louisiana State University Museum of Zoology, Museum of Comparative Zoology - Harvard, Milwaukee Public Museum, Montana State University Museum, Michigan State University Museum, North Carolina State Museum of Natural History, Northern Louisiana University Museum, University of Colorado Museum, University of Georgia Museum of Natural History, University of Idaho Museum, University of Michigan Museum, University of South Dakota, United States National Museum of Natural History, University of Texas Arlington, University of Texas - El Paso, and Peabody Museum - Yale. Most museum data were received with the help of Dr. Charles Peterson, Idaho State University, Pocatello. 


\section{INTRODUCTION}

Many amphibians are apparently declining in the western U.S. and world-wide (Corn and Fogelman 1984, Phillips 1990, Yoffe 1992). Acid rain, ozone depletion, pollution by toxic chemicals and heavy metals, predation and/or competition by exotic species, habitat alteration, climate change, disease, immune system problems, and some combination of these factors have all been suggested as possible causes (Corn and Fogelman 1984, Phillips 1990, Yoffe 1992).

Bass have been introduced into waters on or near the Lewis and Clark National Forest (L\&CNF) and have been implicated in declines of native amphibian populations in some areas. Past forestry practices and large scale logging continue to be detrimental to resident herpetofauna (Bury et al. 1991). The Tailed Frog (Ascaphus truei), present on the L\&CNF, is thought to be one of the most sensitive indicators of stream-side and aquatic community health in forested landscapes (R. B. Bury, pers. comm.). Preliminary data indicate the Northern Leopard Frog (Rana pipiens) has disappeared over much of its former range in western Montana and is declining in at least some areas of eastern Montana. The US Fish and Wildlife Service now lists the Western Toad (Bufo boreas) as a Candidate (C-2) species in Colorado, Wyoming and New Mexico. Apparent declines have recently been reported in northern Idaho (C. Peterson pers. comm.), northwest Montana (Werner and Reichel 1994), Yellowstone National Park (Peterson et al. 1992), Wyoming, and Colorado (Carey 1993).

The U.S. Fish and Wildlife Service lists two Montana amphibians and two reptiles as candidate species: the Spotted Frog (C2) (Rana pretiosa), Tailed Frog (C2), Short-horned Lizard (Phrynosoma douglasi) and Northern Sagebrush Lizard (Sceloporus graciosus graciosus). The U.S. Forest Service Region 1 lists the Coeur díAlene Salamander (Plethodon idahoensis) as ìSensitiveî and is considering adding several other amphibians. The Montana Natural Heritage Program and the Montana Department of Fish, Wildlife and Parks list 6 amphibians [Coeur díAlene Salamander, Idaho Giant Salamander (Dicamptodon aterrimus), Tailed Frog, Canadian Toad (Bufo hemiophrys), Spotted Frog, Wood Frog (Rana sylvatica)] and 7 reptiles [Snapping Turtle (Chelydra serpentina), Spiny Softshell (Apalone spinifera), Short-horned Lizard, Sagebrush Lizard, Western Hognose Snake (Heterodon nasicus), Smooth Green Snake (Opheodrys vernalis), Milk Snake (Lampropeltis triangulum)] as species of special concern in the state. The Northern Leopard Frog and Western Toad (Bufo boreas) are being considered for addition to the list. Eight of these species, the Tailed Frog, Western Toad, Spotted Frog, Northern Leopard Frog, Spiny Softshell, Short-horned Lizard, Western Hognose Snake, and Milk Snake occur or potentially occur on the L\&CNF. 


\section{METHODS AND MATERIALS}

Historic locations of amphibians and reptiles were recorded from literature (see Bibliography) and museum specimen records. Records were received from over 20 major museums which have computerized their collections in North America (see Acknowledgments). Locations derived from these sources have been entered into a database and digitized. Records from the Museum of Vertebrate Zoology, Berkeley, California, have yet to be received.

Survey sites were chosen based on 4 criteria: 1) high priority sites as determined by the L\&CNF; 2) location of streams, seeps and wetlands on topographic maps; 3 ) accessibility of the wetlands by roads or hiking trails; and 4) conversations with district biologists regarding stream-seep-wetland locations and past Forest Service surveys. Based on the above, 3-6 sites were chosen daily for surveys. Ten minutes to 2 hours were spent at each site, depending upon the size of the area and what was found. Initially, the entire shoreline, or a major part thereof, was searched by walking slowly along the edge and up into the surrounding vegetation, including rolling over rocks and logs. At regular intervals, the aquatic habitat was sampled for tadpoles or larvae using dipnets. If the initial sampling showed amphibian/reptile species present, further effort was expended in order to get some idea of abundance and distribution.

An attempt was made to capture at least the first few individuals of a species seen at a survey site. The species name was recorded along with developmental stage and sex (if possible); the animals were then released. Representative samples of the more common species in an area were preserved for permanent museum records and are deposited at the Idaho State University Museum. Water temperature, air temperature, and a general description of the area were recorded. Standard data sheets used during this project are given in Appendix 1; the amphibian survey data sheet was developed by U.S. Fish and Wildlife Service and is used extensively by a variety of researchers in the western U.S. Much site-specific data was gathered during these surveys; not all data has been analyzed or is presented in this report, but is available from the Montana Natural Heritage Program. 


\section{RESULTS AND DISCUSSION}

A total of 40 sites were surveyed of which 22 had one or more amphibian or reptile species present (Figure 1, Appendices 2 and 3). Although no species were found at 18 sites, their absence may have been due to the time of day, weather conditions, or other factors at the time of sampling. With three exceptions, all of the sites were on L\&CNF land.

In addition to the 40 surveys, there were a number of sightings (i.e. road kills, chance observations) for which data are available and the sightings considered reliable. Species location data from surveys, chance encounters, and historic records (from the literature and museum specimens) are listed in Appendix 4. Distribution maps were created using survey and sighting data and historical records; inset statewide maps for each species are based on sight and specimen records, both recent and historic.

No previous publications or reports on reptiles or amphibians concentrate on the L\&CNF area. There is a publication on the Tiber Reservoir area to the north (Mosimann and Rabb 1952). Based museum specimens, publications, surveys and incidental observations, six amphibians and two reptiles have been reported on the L\&CNF; an additional four amphibians and nine reptiles may eventually be found to occur there. Six amphibian and two reptile species were actually observed during the study. The following results are presented as a species summary for the Forest as a whole, followed by specific information on each division (and mountain range within the Jefferson Division).

In the following species accounts, the section on iSimilar Speciesî covers species only which are known or suspected to occur in Montana; outside Montana other confusing species may occur which are not covered in this report. Photos of all Montana amphibians and reptiles may be found in Reichel and Flath(1995). 
Herp Survey Locations on or near the Lewis \& Clark National Forest

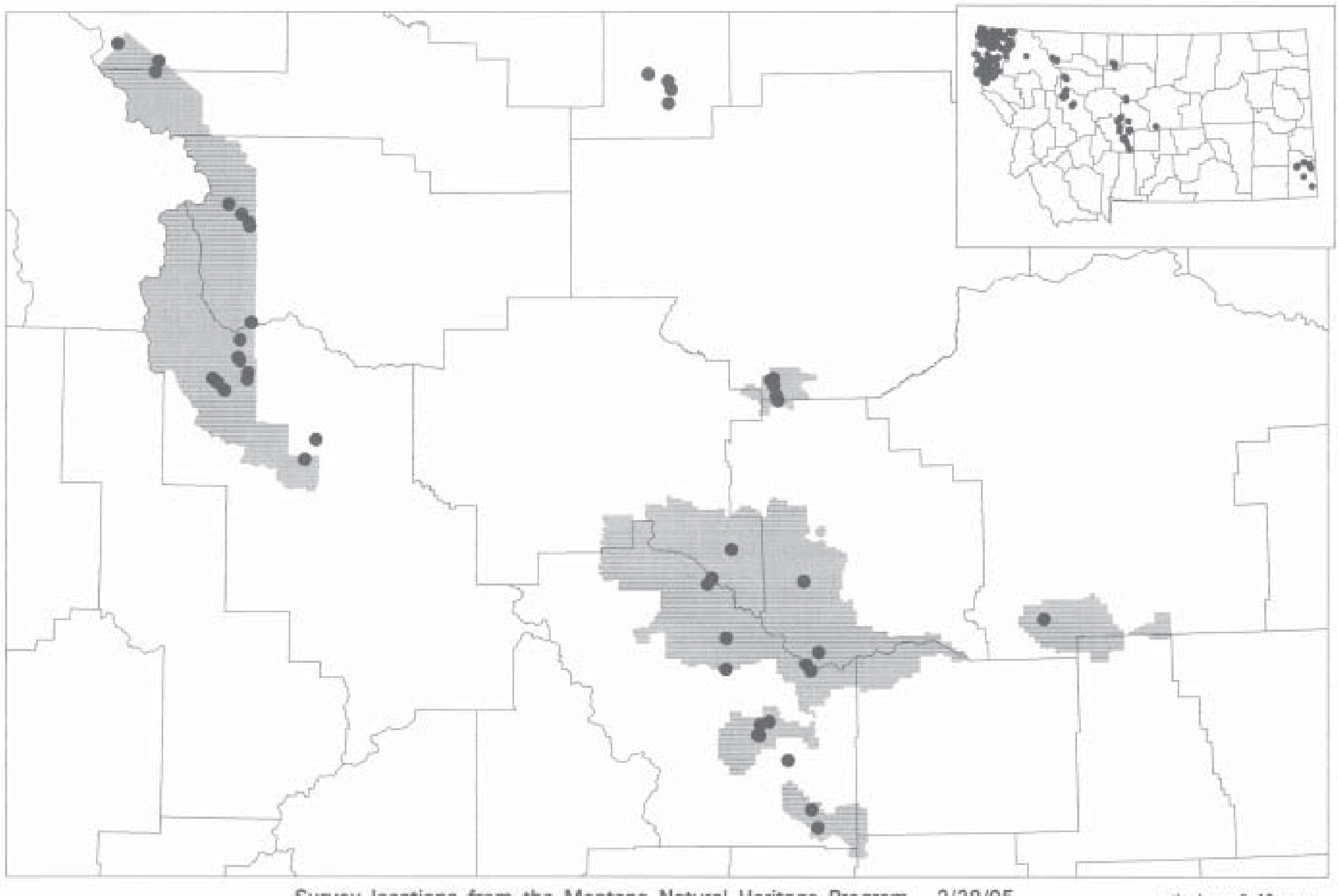

Survey locations from the Montana Natural Heritage Program, 2/28/95 
Occurrences of Ambystoma macrodactylum on or near the Lewis \& Clark National Forest

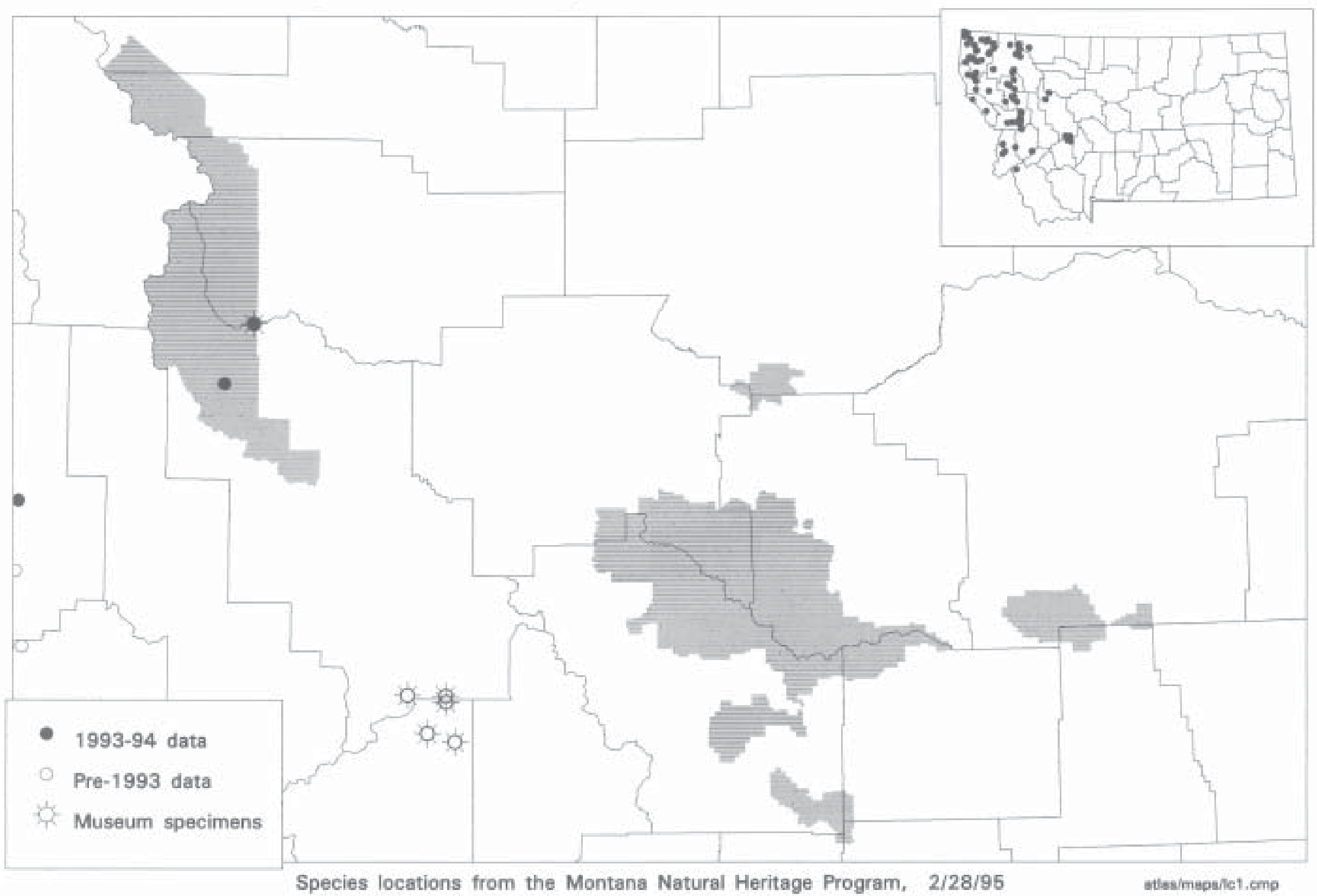




\section{Species known to be present on the Lewis and Clark National Forest}

\section{Long-toed Salamander (Ambystoma macrodactylum)}

Description: Adults are dark gray to black with an irregular (and sometimes broken) green to yellow stripe down the middle of the back. Adult snout-vent length varies from 2 to 3.25". All salamanders have smooth moist skin without scales.

Eggs and Larvae: Egg masses are typically laid in small clusters of 5-100 eggs but may be laid singly (Nussbaum et al. 1983). Within the clear gelatinous eggs, the embryos are somewhat lightcolored, while frog and toad embryos are dark (except in Tailed Frogs). Larval Long-toed Salamanders are typically brown- or gray-colored, are found in ponds, have three external gills, and are relatively small $(<1.75$ " snout-vent) and slender. They are distinguished from Tiger Salamander larvae by the 9-13 gill rakers on the inside of the 3rd gill arch (17-22 rakers on the Tiger Salamander); they are also smaller and lack the large head and mouth.

Similar species: Adult Long-toed Salamanders can be distinguished from Coeur díAlene Salamanders by the longest toe on the hind foot which is longer than the sole and a yellow throat patch. Longtoed Salamanders lack a groove running vertically from nostril to mouth.

Habitat and Habits: Long-toed Salamanders are found in a wide variety of habitats from sagebrush to nearly alpine. They breed in ponds or lakes (very rarely in slow moving streams), usually those without fish present. Adults go to the breeding ponds immediately after snow-melt and are usually the earliest breeding amphibians in western Montana. In the Pacific Northwest, eggs hatch in 3-6 weeks and metamorphosis occurs after 2-14 months (Nussbaum et al. 1983, Leonard et al. 1993). Long-toed Salamanders were found in only two locations on the L\&CNF. The earliest observation was of three egg masses nearly ready to hatch and about 500 recently-hatched larvae in a marshy, backwater pond off Wood Creek on 27 May 1994. A mid-sized larva was also seen in a beaver pond in Wagner Basin on 5 July 1994. Individuals were found only in the Rocky Mountain Ranger District (RMRD) from 4600 - $5720 \mathrm{ft}$. elevation. They occurred with the Spotted Frog in the Wood Creek pond.

Surveying: Larvae can readily be seen in ponds during the day and sampled with a dipnet; egg masses may be harder to see. During the breeding season, adults may also be seen in the water, particularly during night surveys. During the rest of the spring, summer and fall, adults may occasionally be found in and under logs on the forest floor. Metamorphosed individuals are active at night, particularly when it is warm and rainy; they may be captured at this time by either night searches or pitfall traps.

Status: The Long-toed Salamander is the most common salamander in western Montana. Preliminary indications are that the Long-toed Salamander is uncommon and locally distributed in the RMRD of the L\&CNF, the eastern edge of its range.

Montana Natural Heritage Program rank: G5 S5. 
Occurrences of Ascaphus truei on or near the Lewis \& Clark National Forest

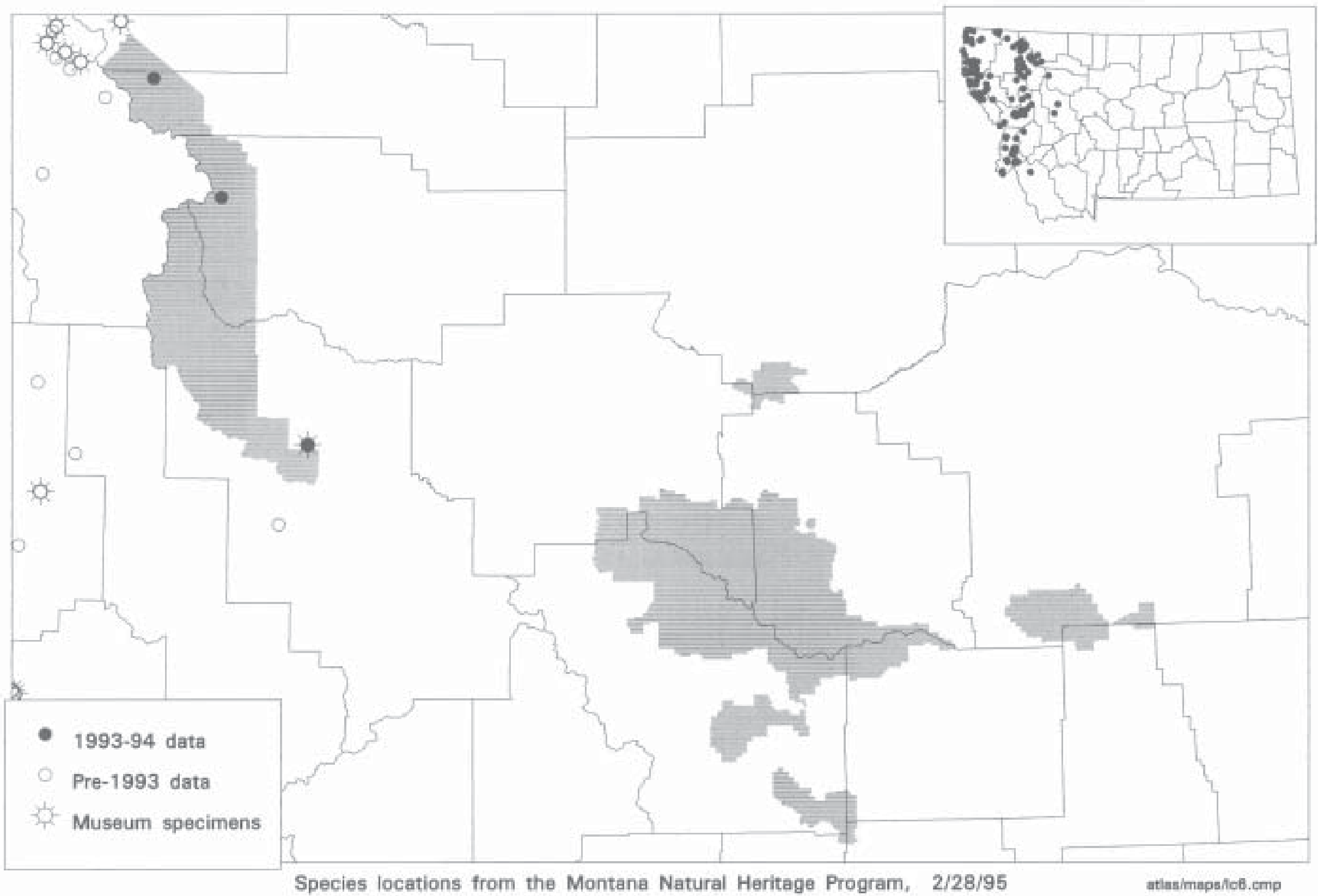


Tailed Frog (Ascaphus truei)

Description: Adults are gray or brown with gray, brown, or occasionally yellow blotches; the skin has a distinctly bumpy texture. The adult has a snout-vent length of 1.5-2" and lacks a tympanum. The outer toe of the hind foot is broader than the other toes. The male has a bulbous itailî which acts as a penis.

Eggs and Larvae: Approximately 50 eggs are laid in rosary-like strings attached to the underside of rocks. The tadpole (up to 2 "long) is unique in that it has a large mouth modified into a sucker; the color is quite variable.

Similar species: No other frog or toad has the outer toe of the hind foot broader than the other toes; all other frogs and toads have a tympanum behind each eye.

Habitat and Habits: Tailed Frogs are found in and along small, swift, cold mountain streams. In the L\&CNF, they have been found only on the RMRD in four locations (Appendix 3, 4). The elevations range from 4900 feet in Falls Creek to about 6000 feet in a small stream on the Mount Wright trail. This elevation range will likely increase with additional sightings from the area. In the Cascade Mountains of Washington and Oregon, the Tailed Frog appears to be very sensitive to siltation and frequently disappears in and downstream from clearcuts and water diversions (Bury, pers. comm.). Preliminary findings do not indicate that this is the case in Montana. Eggs are laid during the late summer and take approximately 4 weeks to hatch. Tadpoles take 1-4 years to metamorphose, depending on water temperature (Nussbaum et al. 1983; Metter 1967). Sexual maturity in Montana is attained at ages 6-7, (Daugherty and Sheldon 1982) which is the latest age for sexual maturity of any North American amphibian.

Surveying: Tadpoles are frequently found while electro-shocking fish. They may also be found by turning over rocks in rapid water with a net held just downstream. Adults are best found by walking up streams starting 30-60 minutes after dark.

Status: The Tailed Frogs in this report are the northeastern-most records for the species. Tailed Frogs are known from a few other locations east of the Continental Divide in the Beaverhead National Forest. While Tailed Frogs should be considered a species with a very localized distribution on the RMRD of the L\&CNF, it may be more common and widespread in suitable habitat than is currently known. It is common and widespread in western Montana. Currently it is a USFWS Candidate species (C-2).

Montana Natural Heritage Program rank: G5 S3S4. 


\section{Occurrences of Bufo boreas on or near the Lewis \& Clark National Forest}

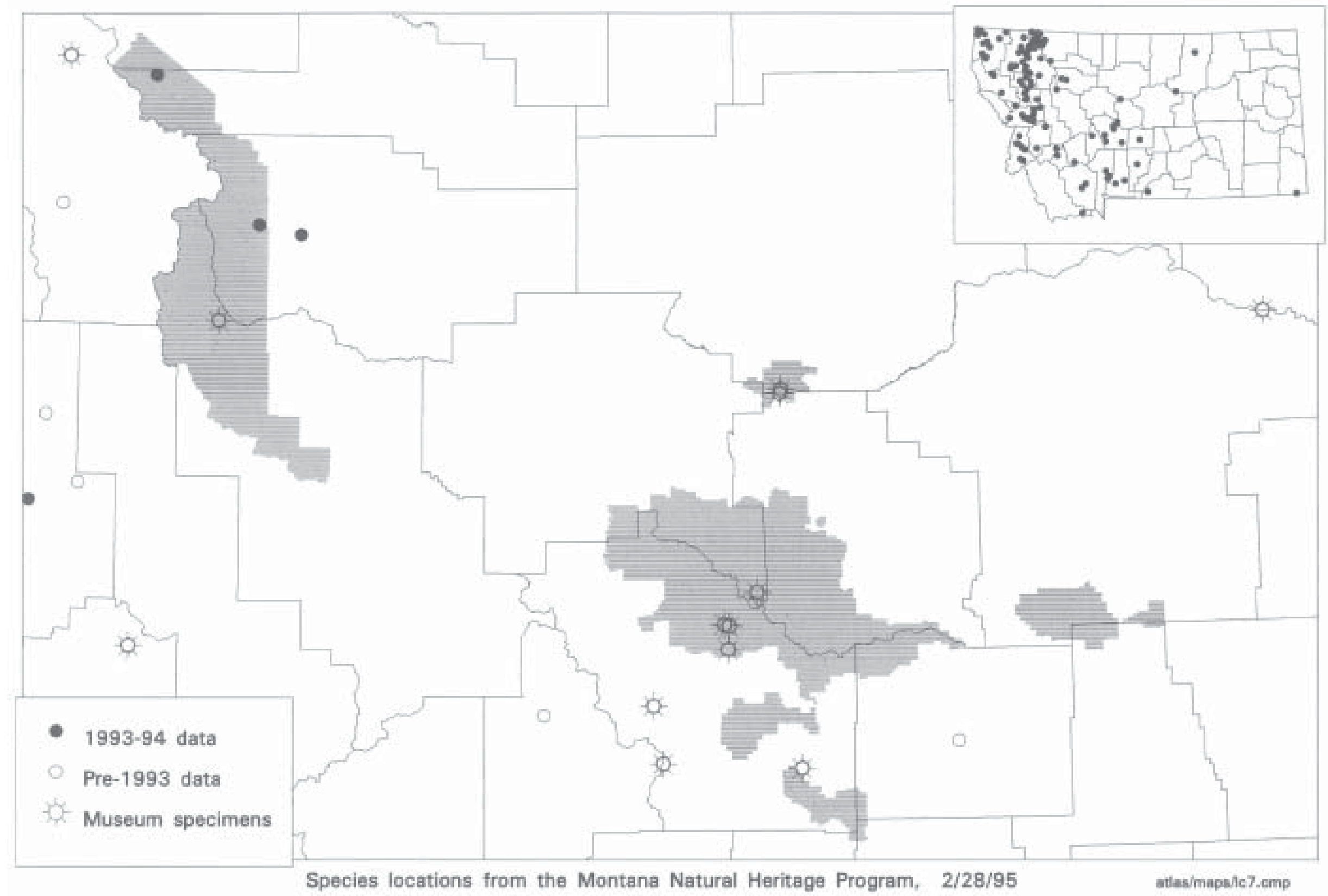




\section{Western Toad (Bufo boreas)}

Description: Adults are colored with a gray, brown, or olive-green mottling and a prominent white or yellowish line down the center of the back; very young transformed toads typically lack the dorsal line, and the warts are often red-brown in color. The pupils are horizontal. The adult has a body length of 2.5-5". There are no cranial crests and the skin is relatively dry with many warts and glands present.

Eggs and Larvae: Eggs are laid in long, clear, double strings, and each has a black embryo. Tadpoles are typically jet black, while all the Montana frog species tadpoles are green or bronze (except for some Tailed Frogs).

Similar species: Other Montana toads have cranial crests between their eyes. The Plains Spadefoot has one tubercle on the sole of the hind feet, a vertical pupil, and smoother skin. NOTE: It is very difficult to distinguish among the four Montana toad species in recently-transformed toadlets.

Habitat and Habits: Adults are largely terrestrial and found in a variety of habitats from valley bottoms to high elevations; they breed in lakes, ponds, and slow streams with a preference for shallow areas with mud bottoms. Breeding and egg laying in Montana usually takes place 1-3 months after snowmelt, from April at lower elevations to July at higher sites. Western Toads were reported from only two locations on the L\&CNF in 1994. We found eggs in a beaver pond on a backwater of the Teton River on 26 May 1994; one clutch was about half developed the other two recently laid. Mike Enk reported a single adult along East Fork Woods Creek. Small tadpoles were seen on 21 June 93 at Pine Butte Swamp Preserve. Tadpoles are typically 2-3 months old at metamorphosis in Montana, depending on water temperature (Black 1970). Following metamorphosis, hundreds of small toads, many with the tails still present, can be found on the shores of breeding ponds.

Surveying: Tadpoles are easily seen in ponds during the day and can be sampled with a dipnet. During the breeding season, adults may be seen in the water but at other times are found in more terrestrial habitats.

Status: Tadpoles and eggs of the Western Toad were observed at only one site during the 1994 survey in the L\&CNF; adults were seen at only a single additional site. None were seen in the Highwood, Little Belt, or Crazy Mountains, although historic records exist from all three ranges (Appendix 3,4). The rarity of this species on the RMRD and lack of recent sightings in the Jefferson Division is of concern. The U.S. Fish and Wildlife Service now lists this species as a Candidate (C-2) species in Colorado, Wyoming, and New Mexico. Apparent declines have recently been reported in northern Idaho (C. Peterson pers. comm.), northwest Montana (Werner and Reichel 1994), Yellowstone National Park (Peterson et al. 1992), Wyoming, and Colorado (Carey 1993). We would recommend that all sightings of this species be reported and that a monitoring program be set up. Montana Natural Heritage Program rank: G4 S4. 
Occurrences of Pseudacris triseriata on or near the Lewis \& Clark National Forest

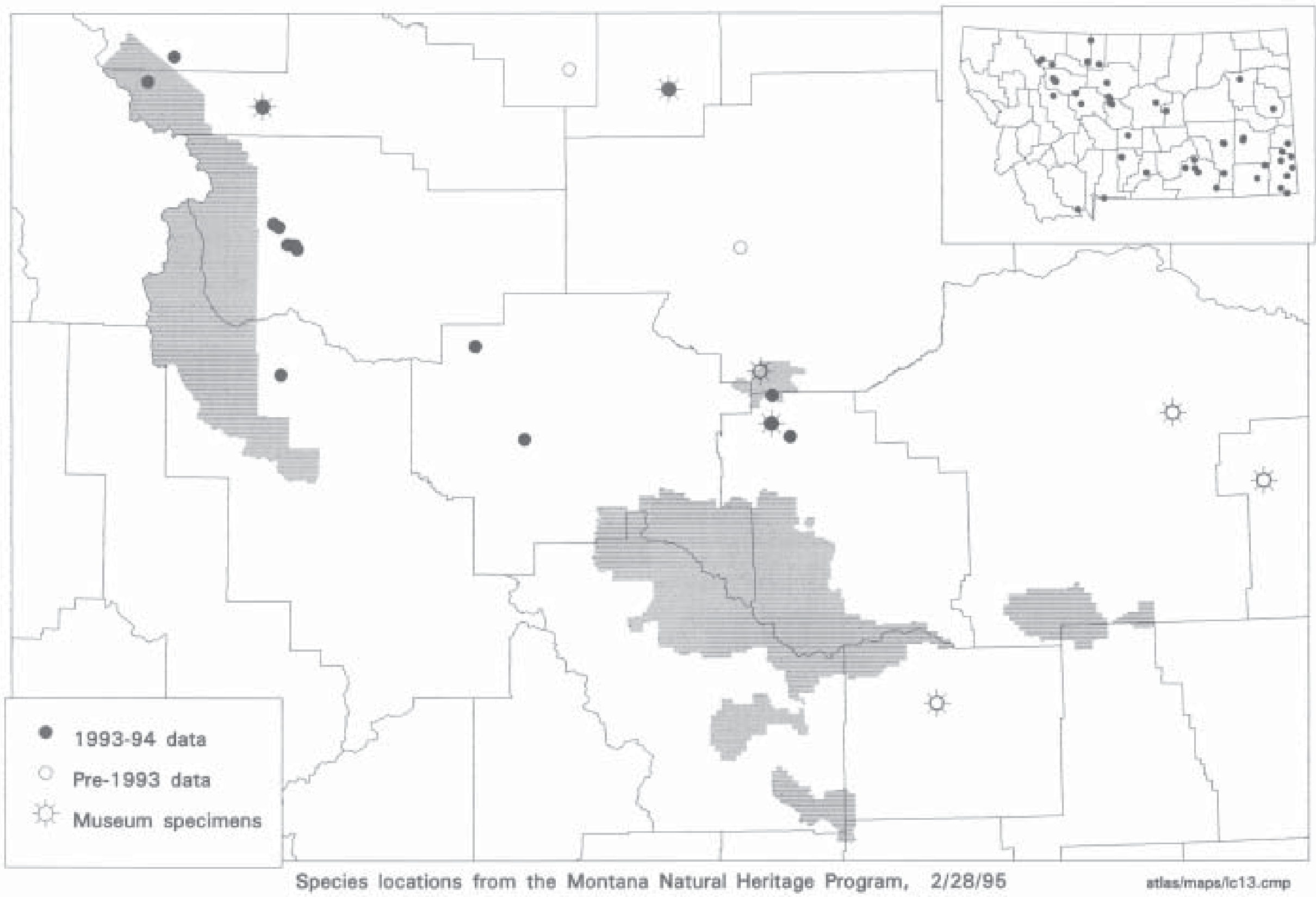




\section{Western Chorus Frog (Pseudacris triseriata)}

Description: Adults are very small (0.75-1.5") and have tiny, almost unnoticeable toe pads. They have a dark line extending from the snout through the eye to the groin. Basic coloration is quite variable with the background color being green, brown, gray, or reddish. Typically 3-5 dark longitudinal stripes are present on the head and back which may be broken up into spots on some individuals. Eggs and Tadpoles: Eggs are laid in small clusters of 10-100, usually less than 1" across and attached to submerged vegetation (Wheeler and Wheeler 1966, Baxter and Stone 1985). Individual eggs are about $1 \mathrm{~mm}$ in diameter. Tadpoles are brown/bronze and the eyes are located on the sides of the head.

Similar species: Pacific Chorus Frogs (Pseudacris regilla) have obvious toe pads and an eye stripe ending at the shoulder. Recently metamorphosed Ranid frogs could be confused with this species but the coloration differs and the tiny toe pads are lacking.

Habitat and Habits: Western Chorus Frogs are regularly found in the water only during the breeding period in spring. Their presence is obvious during this time due to their call which is given frequently at night and sporadically throughout the day. Calls were heard on or near the L\&CNF from midMay through early June while doing surveys; however, the precise beginning and end of calling in the area is unknown. Following breeding, these frogs move into adjacent uplands and are rarely seen. In eastern Montana they breed in temporary ponds and small lakes surrounded by prairie; in some locations in Montana they are also found in open forested habitats. Eggs hatch in about 2 weeks and tadpoles are about 2 months old at metamorphosis (Wheeler and Wheeler 1966, Nussbaum et al. 1983).

Surveying: Adults are easily surveyed for, using their calls for identification during the breeding season in the spring and early summer. During the breeding season, adults may also be seen in the water, but their small size and habit of freezing or diving when disturbed makes observation difficult; night surveys may be more productive. Egg masses are difficult to find. Tadpoles may be seen in ponds during the day and can be sampled with a dipnet.

Status: Common throughout the prairies of eastern Montana. Probably common at the lower edges of the L\&CNF, especially where open forest or prairie occurs; perhaps uncommon and local within forested habitat at higher elevations. Mike Enk reported two locations with Western Chorus Frogs on the L\&CNF. These included the headwaters of Arrow Creek in the Highwood Mountains and a seep area near Whiterock Creek in the RMRD; an additional historic record exists from lower Highwood Creek (Appendix 4). Numerous others were heard calling just outside the forest boundary.

Montana Natural Heritage Program rank: G5 S5. 
Occurrences of Rana pipiens on or near the Lewis \& Clark National Forest

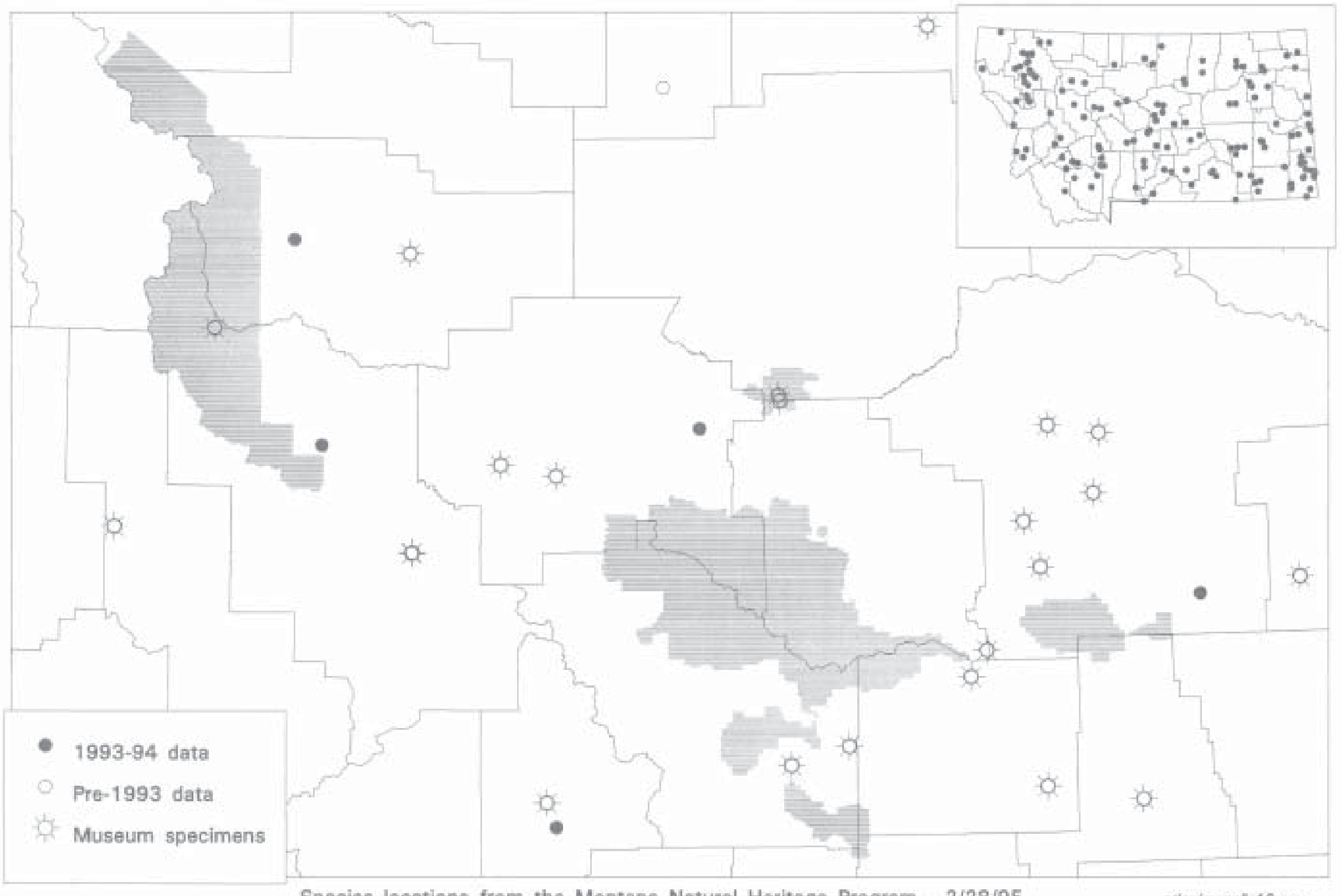




\section{Northern Leopard Frog (Rana pipiens)}

Description: Adults are brown or green with large, dark spots surrounded by light-colored halos on the sides and back. The dorso-lateral folds (ridges along the sides of the back) are usually lighter in color that the surrounding background. The under-side is typically white, but may be creamcolored or yellowish. The adult has a body length of 2-5". Newly transformed froglets may lack spots and are about 1 " in length (Leonard et al. 1993).

Eggs and Tadpoles: Eggs are laid in 2-5" globular masses composed of hundreds to thousands of eggs (Hammerson 1982a, Nussbaum et al. 1983). The tadpoles are brown to dark brown on top with some metallic flecking, whereas the underside is often nearly transparent (Nussbaum et al. 1983). Total length of tadpoles may reach more than 3"; the eyes are located on top of the head.

Similar species: None, although some newly-transformed froglets may lack spots, which makes them extremely difficult to distinguish from Spotted and Wood Frogs.

Habitat and Habits: Northern Leopard Frogs are found in or near water in non-forested habitats. Vegetation is typically dense, as in a cattail marsh or dense sedge-meadow. Breeding takes place in lakes, ponds (temporary and permanent), springs, and occasionally backwaters or beaver ponds in streams. In Colorado, eggs hatch in 4-15 days and tadpoles take 8-15 weeks to metamorphose, depending on water temperature (Hammerson 1982a).

Surveying: Both adults, tadpoles, and eggs are easily seen in and along the water during the day and can be sampled with a dipnet; adults may also be captured by hand. At very low densities adults may be difficult to find and may be detected using a call recorder. Tadpoles are difficult to tell from those of the Spotted Frog in areas where the two species may overlap.

Status: Historically, the Northern Leopard Frog was widespread in Montana but it now appears to be extinct throughout much of the western part of the state. It is still common and widespread in the southeastern corner of the state, but its status is uncertain in central and northeastern Montana. It appears that only localized populations are present on the western edge of the plains. A single historic location is known from on the RMRD of the L\&CNF; that museum specimen was collected in 1958 from the ìSun River, 5500 feet.î Although it is impossible to pinpoint the exact locality for this record, wetlands in the immediate area should be surveyed. Specimens were collected in upper Highwood Creek in the Highwood Mountains in 1962; although searches were conducted in that area during this study, no Northern Leopard Frogs were found. Several other historic records exist from near L\&CNF lands just to the south and east of the Little Belt Mountains. More recent records include: 1) a single individual seen during a two-days period at Pine Butte Swamp in 1993; 2) adults seen along Belt Creek north of L\&CNF lands in 1994; and 3) adults seen along the Dearborn River in 1993. Due to its significant decline and lack of current reports from the L\&CNF, all sightings of this species should be documented.

Northern Leopard Frogs are now absent from many other areas in North America where they were common a few decades ago. Widespread extinctions are known from Alberta (Koonz 1993), Wyoming, Colorado (Hammerson 1982b, Corn and Fogelman 1984), Idaho (Groves and Peterson 1992), Washington, and Oregon (Leonard et al. 1994). Bullfrog and fish introductions, acid rain, ozone depletion, immune system suppression, and iPostmetamorphic Death Syndromeî have all been suggested as causes for frog extirpations in other areas (Corn and Fogelman 1984, Hammerson 1982b, Carey 1993, Leonard et al. 1993). Montana Natural Heritage Program rank: G4 S4. 
Occurrences of Rana pretiosa on or near the Lewis \& Clark National Forest

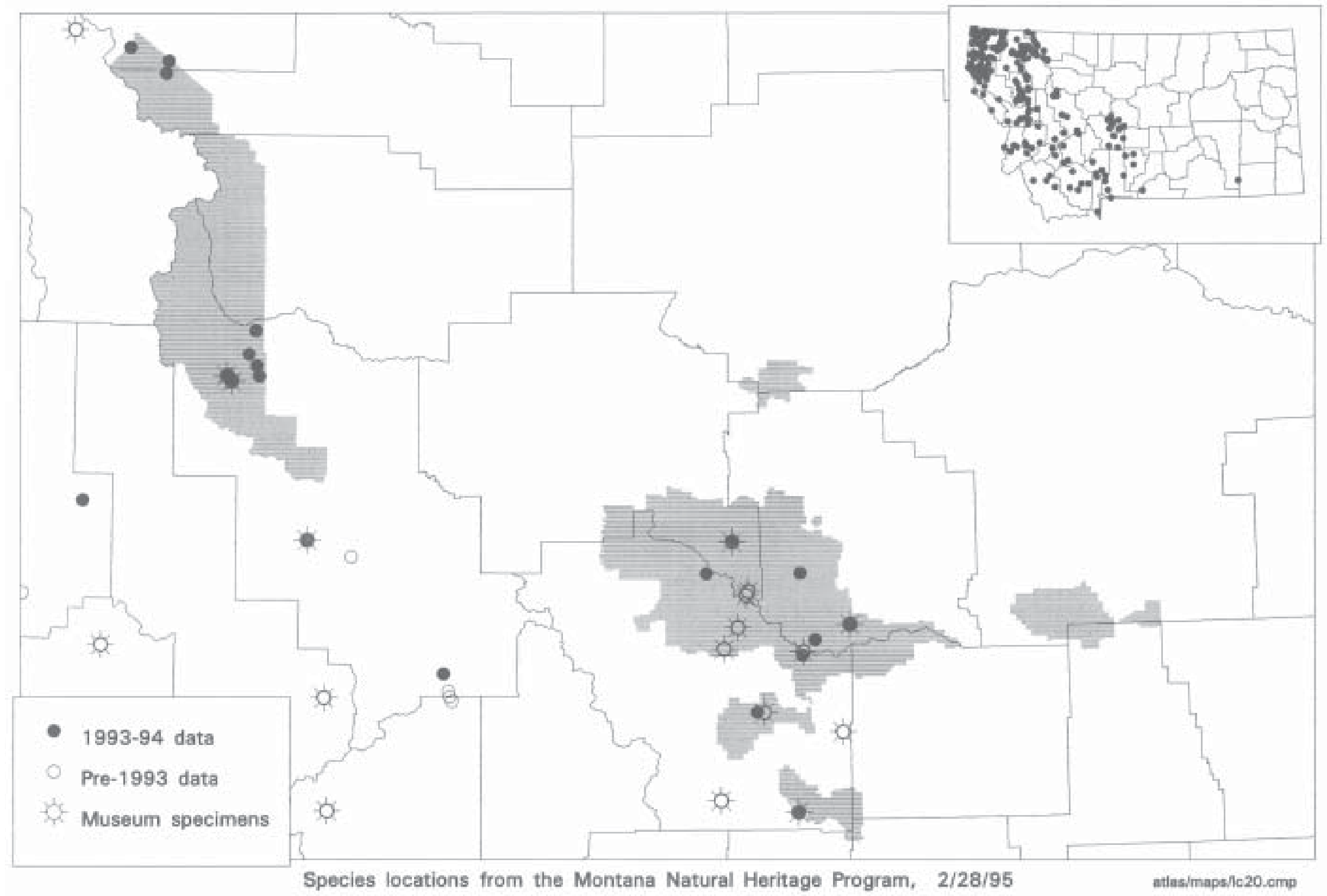




\section{Spotted Frog (Rana pretiosa)}

Description: The adult has a snout-vent length of 2-4". Adults are dark to light brown, gray, or olive green with dark spots (frequently with lighter centers) found on the back, sides and legs. The number and pattern of spotting is quite variable. The back and sides are often covered with small bumps. The underside of the legs is bright red, salmon, or orange; this bright color may extend up to the chin or be replaced by a light, mottled gray on the chin, chest, and/or belly. In younger subadults, bright leg color is often lacking and instead a light, lemon-colored wash is present. In these subadults there is often a dark mask present, with a light jaw stripe extending to the shoulder; both the mask and jaw stripe may be less obvious in larger, older animals.

Eggs and Tadpoles: Eggs are laid in large, globular masses of 150-500 at the surface of the water. The tadpoles are dark green to brown on top with some gold flecking whereas the underside has an iridescent bronze or silver color. Total length of tadpoles may reach 3"; the eyes are located on top of the head.

Similar species: The bright-colored pigment on the undersides of the adultís legs distinguish this species from all other frogs in Montana. Younger individuals, without colored legs, may usually be distinguished from other frogs by a combination of: 1) dorsal spots usually present but not surrounded by light-colored halos; 2) dorsolateral folds present; 3 ) toes without pads at the tips; and 4) a pale gray, (rather than white) belly.

Habitat and Habits: Spotted Frogs are regularly found at the waterís edge in openings within forest habitats. Wetlands in or near treeline are also used, but populations are uncommon in the large, open intermountain valleys. The Spotted Frog was commonly found on both divisions of the L\&CNF from just above the prairie edge at $4860 \mathrm{ft}$. to over $7400 \mathrm{ft}$ elevations near timberline. Individuals were found in every type of wetland habitat, although numbers varied widely from one to 25 or more per site. Breeding takes place in lakes, ponds (temporary and permanent), springs, and occasionally backwaters or beaver ponds in streams. All the egg masses in a particular pond are often found in the same location at the margin of the pond; therefore, the eggs are susceptible to drying up if pond levels recede substantially before hatching. Both eggs and recently hatchedtadpoles were found 27 May 94 at a pond near Wood Creek. Tadpoles were seen from the earliest survey on 27 May 94 to the latest survey on 9 July 94; at that date they seemed a few weeks from metamorphosis. Eggs hatch in 2-3 weeks and tadpoles take 2-14 months to metamorphose, depending on water temperature (Nussbaum et al. 1983, Turner 1958). Young and adult frogs often disperse into marsh and forest habitats but are not usually found far from open water.

Surveying: Adults, tadpoles, and eggs are easily seen in and along the water during the day and can be sampled with a dipnet; adults may also be captured by hand. Many adults may leave the breeding ponds following egg laying and move to nearby feeding areas for the summer. Tadpoles are difficult to distinguish from those of the Northern Leopard Frog in areas where the two species overlap.

Status: The most common frog on the L\&CNF and in western Montana. It was observed on the RMRD, and the Little Belt, Crazy, and Castle Mountains of the Jefferson Division, however few breeding location are known at this time and, if found, should be reported. It was not seen in the Highwood or Snowy Mountains; any sightings from those mountain ranges should be reported. The species is currently a U.S. Fish and Wildlife Service Category 2 Candidate species in Montana; elsewhere in its range it is listed as a C-1, with Threatened/Endangered status warranted but precluded by work on higher priority species (U.S. Fish and Wildlife Service 1993). Significant declines are known from the southern end of the range (Nevada, southern Idaho, Utah). While significant declines are also apparent in coastal Washington (McAllister et al. 1993), Oregon, and California, recent (as yet unpublished) research indicates that those populations are actually a different species.

Montana Natural Heritage Program rank: G4 S4. 
Occurrences of Thamnophis elegans on or near the Lewis \& Clark National Forest

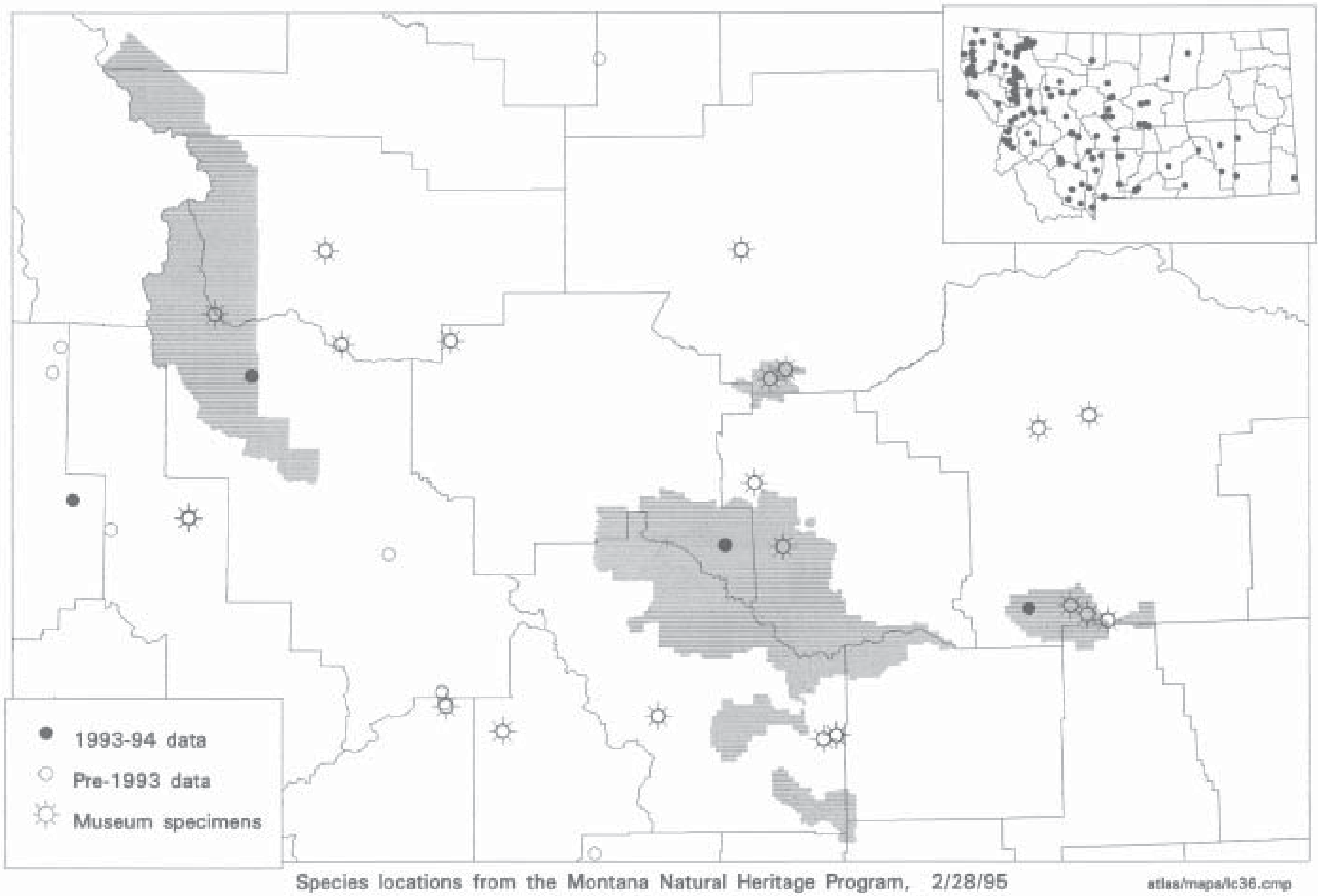


Western Terrestrial Garter Snake (Thamnophis elegans)

Description: Adult Western Terrestrial (or Wandering) Garter Snakes are smaller in body size than the Common Garter Snake, their length varying from 18-43". Three yellow longitudinal stripes are present (one dorsal, two lateral), but the dorsal stripe is much narrower than that of the Common Garter Snake. A distinctive feature of the Western Terrestrial Garter Snake is a series of alternating black spots which run the length of the body between, and somewhat on, the yellow stripes. The background color between the stripes tends to be more gray compared to the dark brown found in the Common Garter Snake. The ventral surface has a series of dark black/brown blotches which may cover most of the surface. The dorsal scales are keeled and there are normally 8 upper labial scales.

Young: The coloration of young snakes is similar to that of the adults; young are live-born.

Similar species: See Common and Plains Garter Snakes.

Habitat and Habits: The habitat and habits of the Western Terrestrial Garter Snake are similar to the Common Garter Snake, i.e., they are found in most habitats but are particularly common around wetlands. On the L\&CNF the species was found between $5000 \mathrm{ft}$ and $6000 \mathrm{ft}$ but probably occurs much lower and higher. Females give birth to 4-19 young during the summer (Stebbins 1985).

Surveying: Timed sight surveys may be conducted around wetlands and riparian feeding areas or at denning areas where higher concentrations of garter snakes occur; clear mornings are the best survey times. Much distributional information may come from recording incidental sightings. More intensive research may be done using funnel traps in combination with drift fences. More intensive research and survey projects may use mark-recapture or radiotelemetry techniques.

Status: Western Terrestrial Garter Snakes were found in the RMRD, Little Belt Mountains, and Big Snowy Mountains of the L\&CNF. There is also a historic record of them from the Highwood Mountains in additional to historic records from all ranges where they were found in 1994. Given the small number of records from throughout the area, all records should be documented until the distribution is better understood; of particular interest would be documentation of denning sites. Sightings of elegans from the Castle, Crazy, and Little Snowy Mountains should be documented to confirm their presence in those ranges.

Montana Natural Heritage Program Rank: G5 S5. 
Occurrences of Thamnophis sirtalis on or near the Lewis \& Clark National Forest

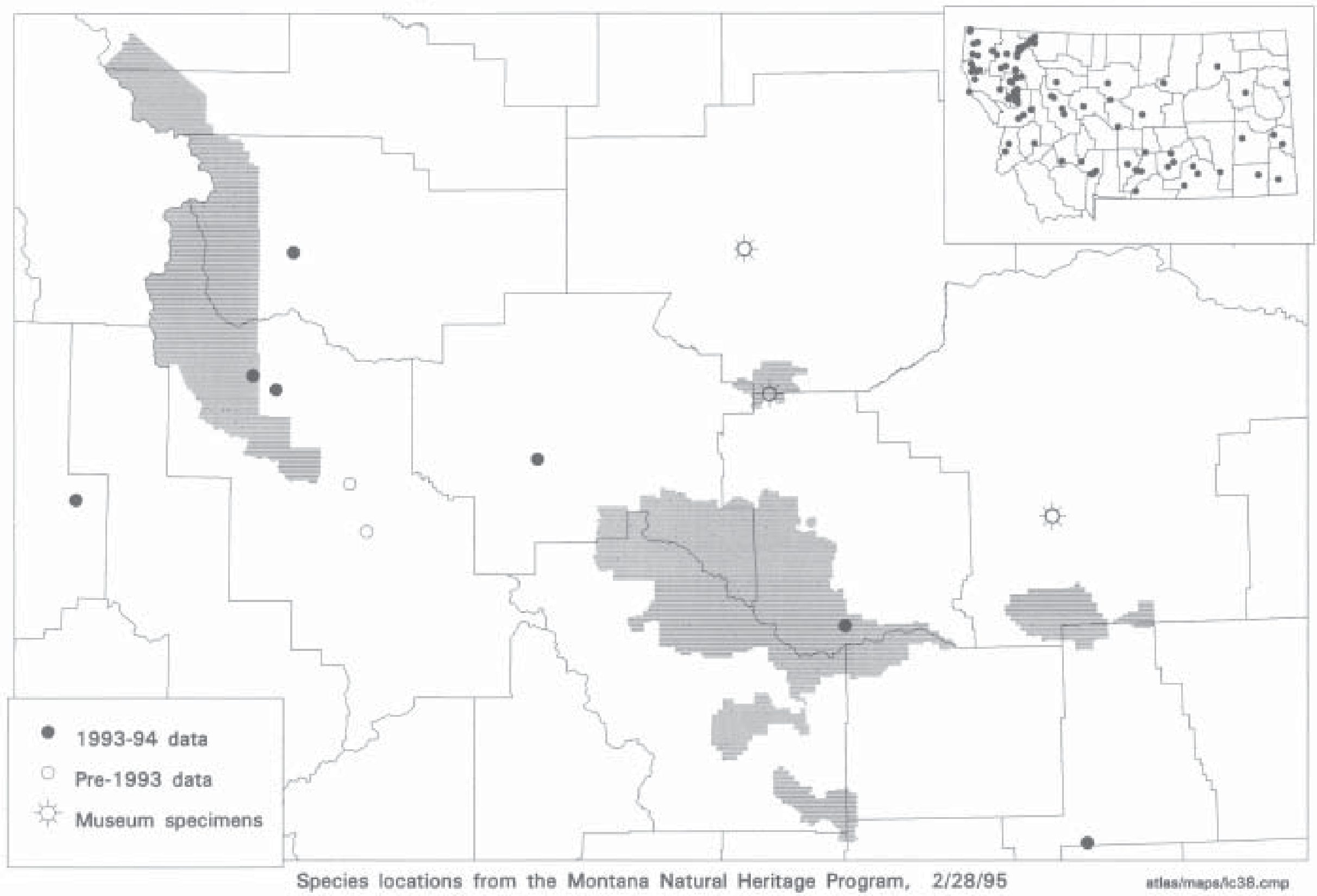




\section{Common Garter Snake (Thamnophis sirtalis)}

Description: The Common Garter Snake consists of two color phases in western Montana, both ranging from 18-52" in length. Both phases have three yellow longitudinal stripes: one located dorsally and one on each side. Between the yellow stripes is a black stripe broken with red spots in one color phase but lacking red in the other. Ventral coloration varies from yellow to bluish, and some individuals of the red-sided color phase have small black spots on the edge of the ventral scales. The dorsal scales are keeled, and normally there are 7 upper labial scales. Young: The coloration of young snakes is similar to that of the adults; young are live-born.

Similar species: The Western Terrestrial Garter Snake has black spots overlapping the dorsal yellow stripe; the background color between stripes tends to be brownish. The Plains Garter Snake has the side yellow stripe on the 3rd and 4th scale rows above the belly scales and the dorsal stripe is often orange or red.

Habitat and Habits: Garter snakes are found in all forest habitats but are more common at lower elevations around marsh-bog-pond situations, where they prey on young fish, frogs, toads, mice and invertebrates. They are sometimes confused with water snakes because of their frequent aquatic exploits, but there are no true water snakes in Montana. Typical of most garter snakes, they emit a noxious secretion when handled and can be aggressive when disturbed. The Common Garter was found between $4100 \mathrm{ft}$ to $5540 \mathrm{ft}$ on or near the L\&CNF, but they are likely to occur at lower and much higher elevations. Garter snakes eat a variety of vertebrates and invertebrates, with the Common Garter Snake concentrating more on amphibians than the Western Terrestrial Garter Snake. The Common Garter Snake is a live-bearer giving birth to 12-18 young during the summer in Colorado (Hammerson 1982a).

Surveying: Timed-sight surveys may be conducted around wetlands and riparian feeding areas or at denning areas where higher concentrations of garter snakes occur; clear mornings are the best survey times. Much distributional information may come from recording incidental sightings. More intensive research may be done using funnel traps in combination with drift fences. More intensive research and survey projects may use mark-recapture or radiotelemetry techniques.

Status: Common Garter Snakes were found in the RMRD and Little Belt Mountains of the L\&CNF. There is also a historic record of them from the Highwood Mountains. Given the small number of records from throughout the area, all records should be documented until the distribution is better understood; of particular interest would be documentation of denning sites. Sightings of sirtalis from the Castle, Crazy, and Snowy Mountains should be documented to confirm their presence in those ranges. Only the red-sided color phase was observed in the present survey, however the color phase lacking red spots should be watched for. The relative abundance of this species in this area compared to the Western Terrestrial Garter Snake is not yet clear; in northwestern Montana the Common Garter Snake is currently much less abundant.

Montana Natural Heritage Program Rank: G5 S5. 
Occurrences of Ambystoma tigrinum on or near the Lewis \& Clark National Forest

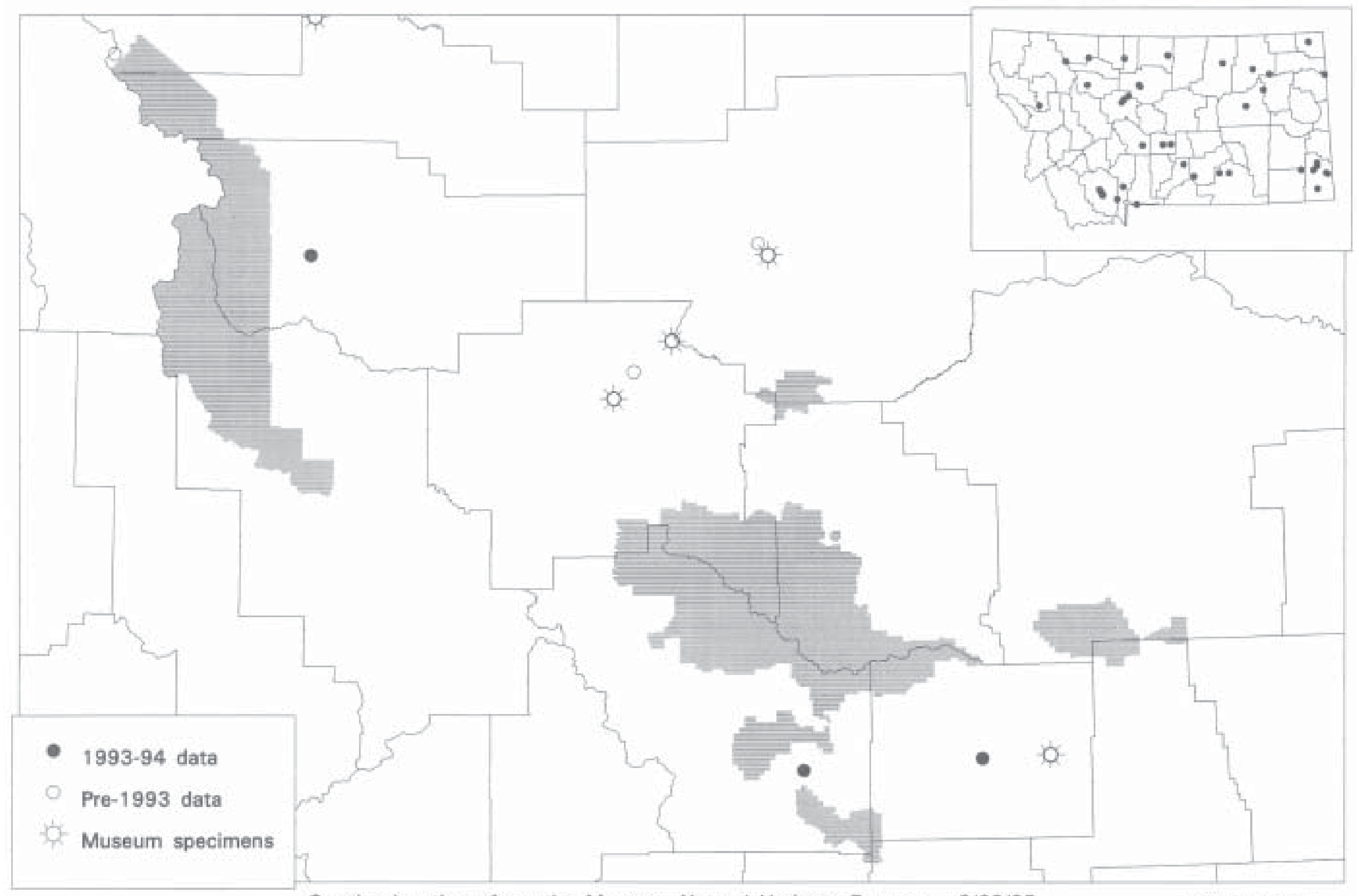

Species locations from the Montana Natural Heritage Program, 2/28/95 


\section{Species Potentially Present on the Lewis and Clark National Forest}

\section{Tiger Salamander (Ambystoma tigrinum)}

Description: Adults have a smooth moist skin without scales and the color pattern is highly variable; usually the background color is dark, with lighter blotches of yellow, tan or green. The adult is large and heavy-bodied with a snout-vent length of 3-6".

Eggs and Larvae: Egg masses are typically laid in small clusters of 5-120, but may be laid singly (Nussbaum et al. 1983, Leonard et al. 1993). They are usually attached to vegetation and placed 2"-10" below the surface of the water (Hammerson 1982a). Larval Tiger Salamanders are typically pale green or brown-colored, though some are nearly white in bentonite clay ponds. They are found in lakes and ponds, have external gills, and are relatively large (0.75-4" snout-vent) and heavy-bodied.

Similar species: Adult Tiger Salamanders have two prominent tubercles on the bottom of each hind foot which Idaho Giant Salamanders lack. Idaho Giant Salamanders also have a more marbled color pattern and a very large head.

Habitat and Habits: Tiger Salamanders in Montana are primarily associated with prairie or agricultural habitats in eastern Montana. They breed in ponds or lakes, usually those without fish present. In arid areas they may also be found in springs, intermittent streams, and stock ponds. In Blue Lake, Madison County, Montana, eggs are laid from early June to mid-August, hatched in about 2 weeks, and metamorphosed after more than a year (Micken 1968, 1971). In Colorado and Wyoming egg laying takes place from mid-March to mid-August (Hammerson 1982a, Baxter and Stone 1985). Eggs hatch in 2-5 weeks in Colorado and metamorphosis occurs after 2-24 months (Hammerson 1982a). Following breeding, adults may remain in the pond or may move to upland areas and live in burrows of their own or in those of other animals. In some locations, such as Blue Lake in Madison County, larval salamanders never transform, but rather become sexually mature and breed while still retaining external gills. This process is referred to as neoteny and these salamanders are called ìaxolotlsî or ìwater dogs.î

Surveying: Larvae and eggs may be seen in ponds during the day and may be sampled with a dipnet. In areas where larvae transform, migrations of hundreds or thousands of newly transformed adults are occasionally seen in mid to late summer or in early fall. During the breeding season, adults are often seen in the water or moving to or away from it. Pitfall and minnow traps may be used at this time to capture adults. The rest of the summer adults are difficult to find; the best techniques may be pitfall traps or driving roads on warm rainy nights.

Status: The most common salamander in eastern Montana. They have not yet been found on the L\&CNF, but there are records of larvae from ponds just south of the Castle Mountains (north of Lennep) and from Pine Butte Swamp Preserve, just east of the RMRD. They should be surveyed for in low elevation ponds and lakes, particularly those without fish and within grassland habitats. Any located on the L\&CNF should be documented. Montana Natural Heritage Program rank: G5 S5. 


\section{Occurrences of Bufo cognatus on or near the Lewis \& Clark National Forest}

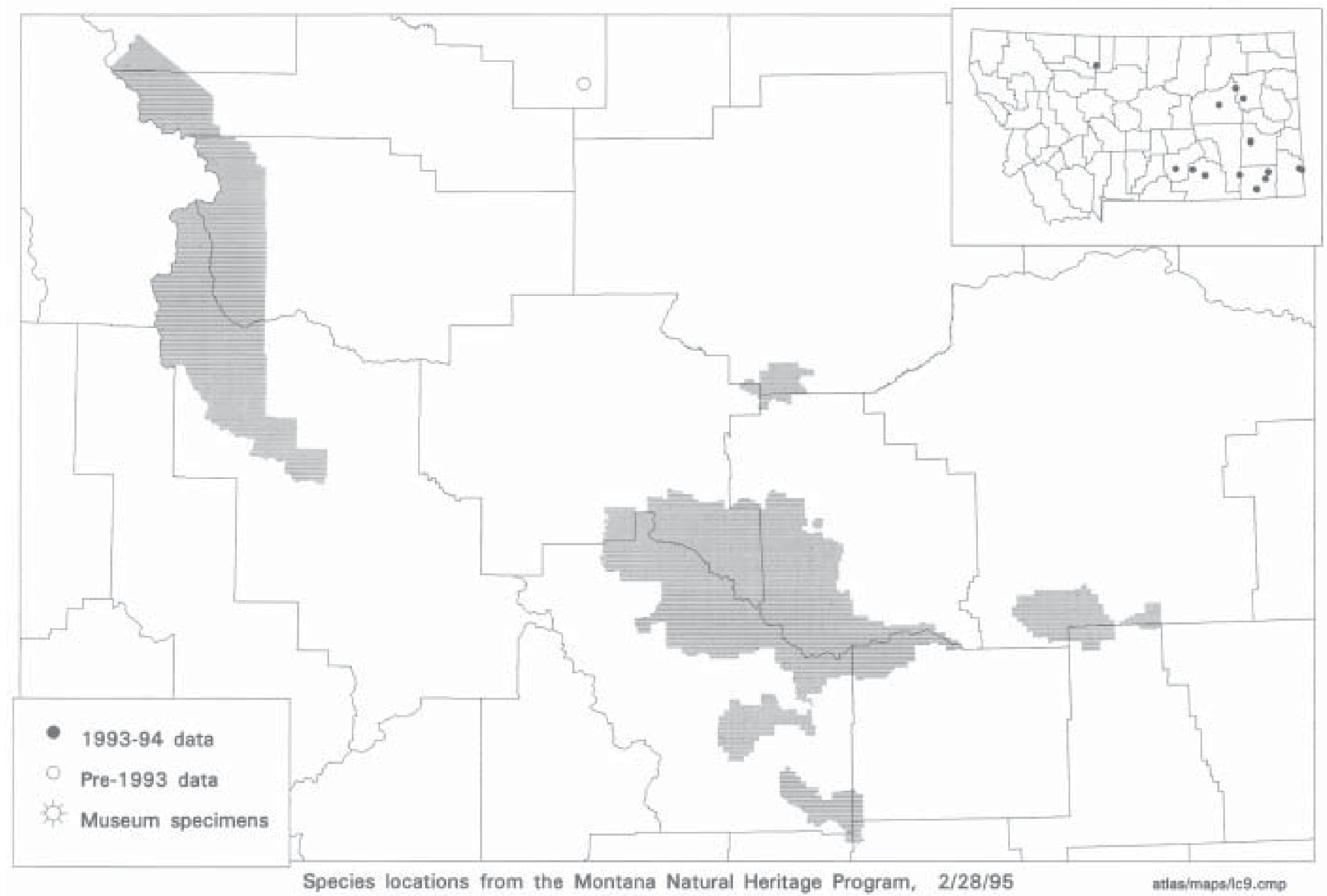


Great Plains Toad (Bufo cognatus)

Description: Adults have dry skin with small warts. The coloration is dominated by a number of large, dark, somewhat symmetrical spots surrounded by light edges on the back. The dorsal background color is gray, light brown or olive green. The Great Plains Toad has converging V-shaped cranial crests between the eyes and post-orbital crests connecting to them at a right angle behind the eyes; the post-orbital crests typically touch the parotoid glands. The pupils are horizontal. The adult has two black tubercles on the hind feet and a body length of 2-3.5".

Eggs and Tadpoles: Similar to the Western Toad.

Similar species: Other Montana toads lack the somewhat symmetrical spotted pattern on the back. NOTE: It is very difficult to distinguish among the four Montana toad species in recently transformed toadlets.

Habitat and Habits: Adults may favor higher elevation grasslands than Woodhouseís Toad which favors floodplains (Bragg 1940, Timkin and Dunlap 1965, Black 1970). They have also been found in agricultural areas and open Ponderosa pine savannahs in southeastern Montana (Black 1970). They are most active at night, spend much of the year underground, and emerge in response to warm rains (Hammerson 1982a). They normally breed in temporary ponds resulting from heavy rains or irrigation runoff or reservoirs with much fluctuation (Bragg 1940, Hammerson 1982a). In Montana they apparently breed from May to July (Black 1970). Females lay strings of eggs which hatch after 2-3 days (Hammerson 1982a). Young typically metamorphose after about 1.5 months, although metamorphosis has been reported in as little as 17 days (Hahn 1968, Hammerson 1982a).

Surveying: Adults may be found by listening for their loud calls on warm $\left(>60^{\circ} \mathrm{F}\right)$ nights following heavy rains (Hammerson 1982a). ìRoad huntingî on warm nights may also be effective. Eggs and tadpoles are seen in ponds during the day and can be sampled with a dipnet; however, identification of toad eggs and tadpoles is difficult or impossible in the field.

Status: Not yet found on the L\&CNF, but known from the prairie region about 70 miles north of the Highwood Mountains. Occurs in localized areas in eastern Montana, with large gaps in its known range. Geographic and habitat relationships with other toads in Montana are not well known. The Great Plains Toad should be watched for at low elevations in prairie or shrub-steppe habitat on the L\&CNF, especially on the Jefferson Division. Any located on the L\&CNF should be well documented with a description indicating how the species was differentiated.

Montana Natural Heritage Program rank: G5 S4. 
Occurrences of Bufo woodhousii on or near the Lewis \& Clark National Forest

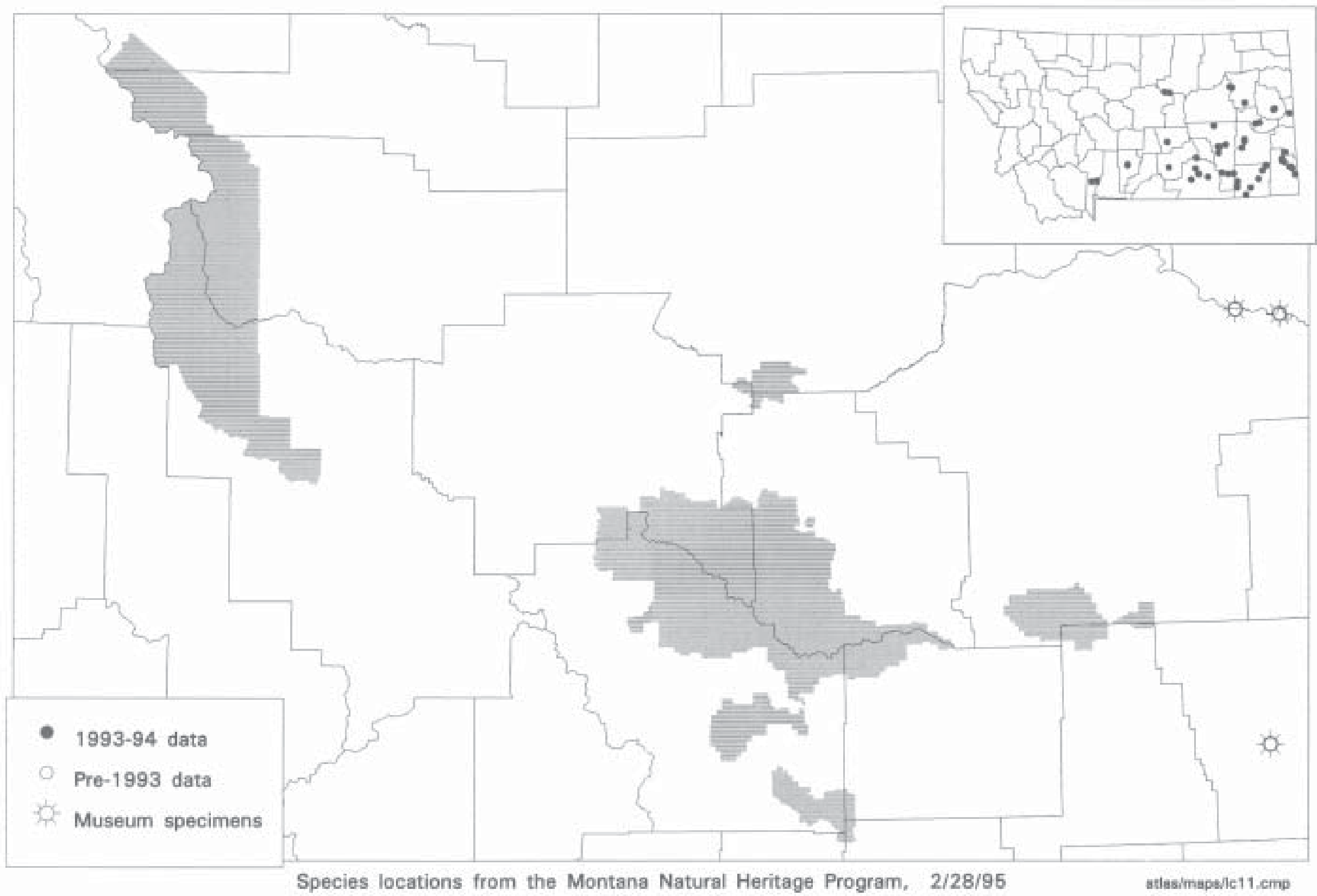




\section{Woodhouseís Toad (Bufo woodhousii)}

Description: Adults have dry skin with small warts, and are gray, brown, or olive-green with paler mottling or spots. A prominent white or yellowish line runs down the center of the back; very young transformed toads typically lack the dorsal line, and the warts are often red-brown in color. Woodhouseís Toad has parallel cranial crests between the eyes and post-orbital crests connecting to them at a right angle behind the eyes; the post-orbital crests typically touch the parotoid glands. If a lump-like boss is present on the snout, it does not extend back between the eyes. The pupils are horizontal. The adult has two black tubercles on the hind feet and a body length of 2.5-4". Eggs and Tadpoles: Similar to those of the Western Toad.

Similar species: Western Toad lacks cranial crests. Great Plains Toad has large, white-bordered, dark, dorsal blotches. The Canadian Toad has a lump between the eyes; frequently the parotoid gland is separated from the post-orbital crest which may be broken or absent. NOTE: It is very difficult to distinguish among the four Montana toad species in recently transformed toadlets.

Habitat and Habits: Adults are partially terrestrial but often found near water. They are usually found in irrigated agricultural areas and flood plains, rather than the more upland areas used by Great Plains Toads (Bragg 1940, Timkin and Dunlap 1965, Black 1970). They are most active at night, although they may at times ben found feeding during the day (Hammerson 1982a). They typically breed in permanent lakes, ponds, reservoirs, and slow streams, with a preference for shallow areas with mud bottoms (Black 1970, Hammerson 1982a, Baxter and Stone 1985). Breeding and egg laying is spread out over the spring and early summer, with known dates from Montana ranging from 4 May to 1 July (Black 1970).

Surveying: Adults may easily be found by using their loud calls for identification on warm $\left(>54^{\circ} \mathrm{F}\right)$ nights; calling peaks during the first few hours after sunset (Hammerson 1982a). iRoad huntingî on warm nights may also be effective. Eggs and tadpoles are seen in ponds during the day and can be sampled with a dipnet; however, identification of toad eggs and tadpoles is difficult or impossible in the field.

Status: Not known from the L\&CNF; the nearest known record, collected in 1918, is from about 30 miles southeast of the Little Snowy Mountains, 1 mile west of Kline. Woodhouseís Toad is relatively common in southeastern Montana, however, its status elsewhere in the state is unclear. Geographic and habitat relationships with other toads in Montana are not well known. It should be watched for at low elevations in prairie or shrub-steppe habitat on the L\&CNF, especially in the Jefferson Division; it could occur along the Smith River. Any located on the L\&CNF should be well documented with a description indicating how the species was differentiated.

Montana Natural Heritage Program rank: G5 S4. 
Occurrences of Scaphiopus bombifrons on or near the Lewis \& Clark National Forest

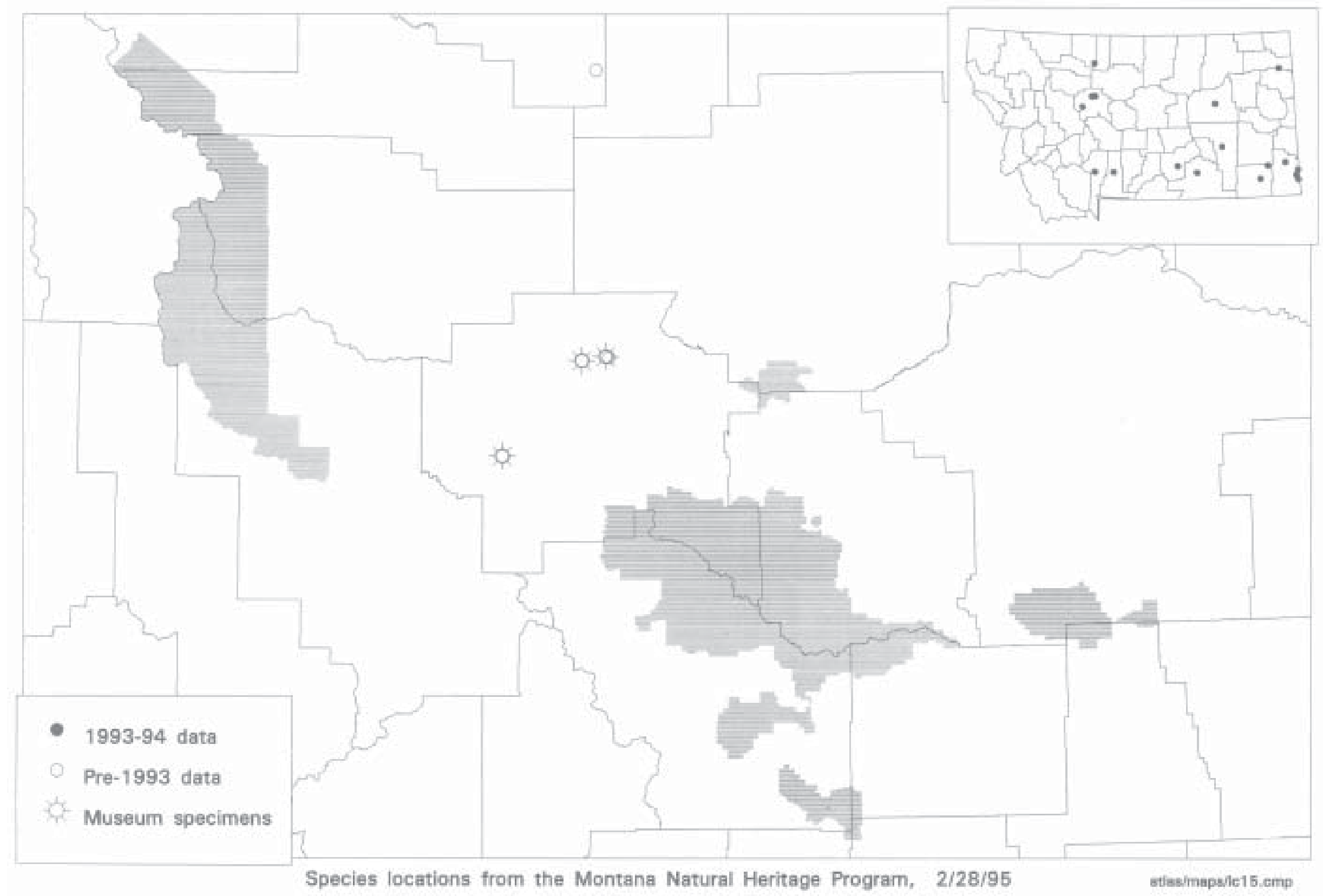


Plains Spadefoot (Scaphiopus [=Spea] bombifrons)

Description: Adults are colored gray or brown with darker mottling on the back and a white belly. Some individuals have indistinct longitudinal streaking. The pupils of the Plains Spadefoot are vertically elliptical and there is a high, hard lump between the eyes. Its skin is less warty than true toads. The adult has a single tubercle on the hind feet and has a body length of less than 2.5". Eggs and Tadpoles: Oval egg masses of 10-250 eggs are attached to underwater plants or debris. Tadpoles are mottled sooty and olive-yellow above and paler below with gold metallic flecking over all; iris is gold.

Similar species: Other Montana frogs and toads have round or horizontally elliptical pupils.

Habitat and Habits: Adults are found in grassland and sagebrush areas, particularly in areas with sandy or loose soil (Wheeler and Wheeler 1966, Hammerson 1982a, Baxter and Stone 1985). Except during breeding, they are seldom found in the water. They are primarily nocturnal and emerge from their burrows only following heavy rains. They breed in shallow temporary pools usually following heavy spring or summer rains (Hammerson 1982a). Males call loudly, with groups being heard for up to a mile. Eggs hatch after 2-3 days and tadpoles transform in 6-10 weeks (Wheeler and Wheeler 1966, Hammerson 1982a).

Surveying: Adults may be easily found by using their calls for identification when breeding at night or by ìroad huntingî on warm, rainy nights. Calling normally takes place only when the temperature is $>50^{\circ} \mathrm{F}$ (Hammerson 1982). Tadpoles are seen in ponds during the day and can be sampled with a dipnet. Surveying is complicated by the long time periods which this species spends underground, especially during droughts.

Status: The Plains Spadefoot is not known from L\&CNF lands; the nearest records are from Cascade County about 20-30 miles west of the Highwood Mountains, WNW of the Little Belt Mountains, and in Great Falls. Locally common in eastern Montana; there are large gaps in the known range. It should be watched for at low elevations in prairie or shrub-steppe habitat on the L\&CNF, especially the Jefferson Division. Any located on the L\&CNF should be welldocumented.

Montana Natural Heritage Program rank: G5 S4? 


\section{Occurrences of Chrysemys picta on or near the Lewis \& Clark National Forest}

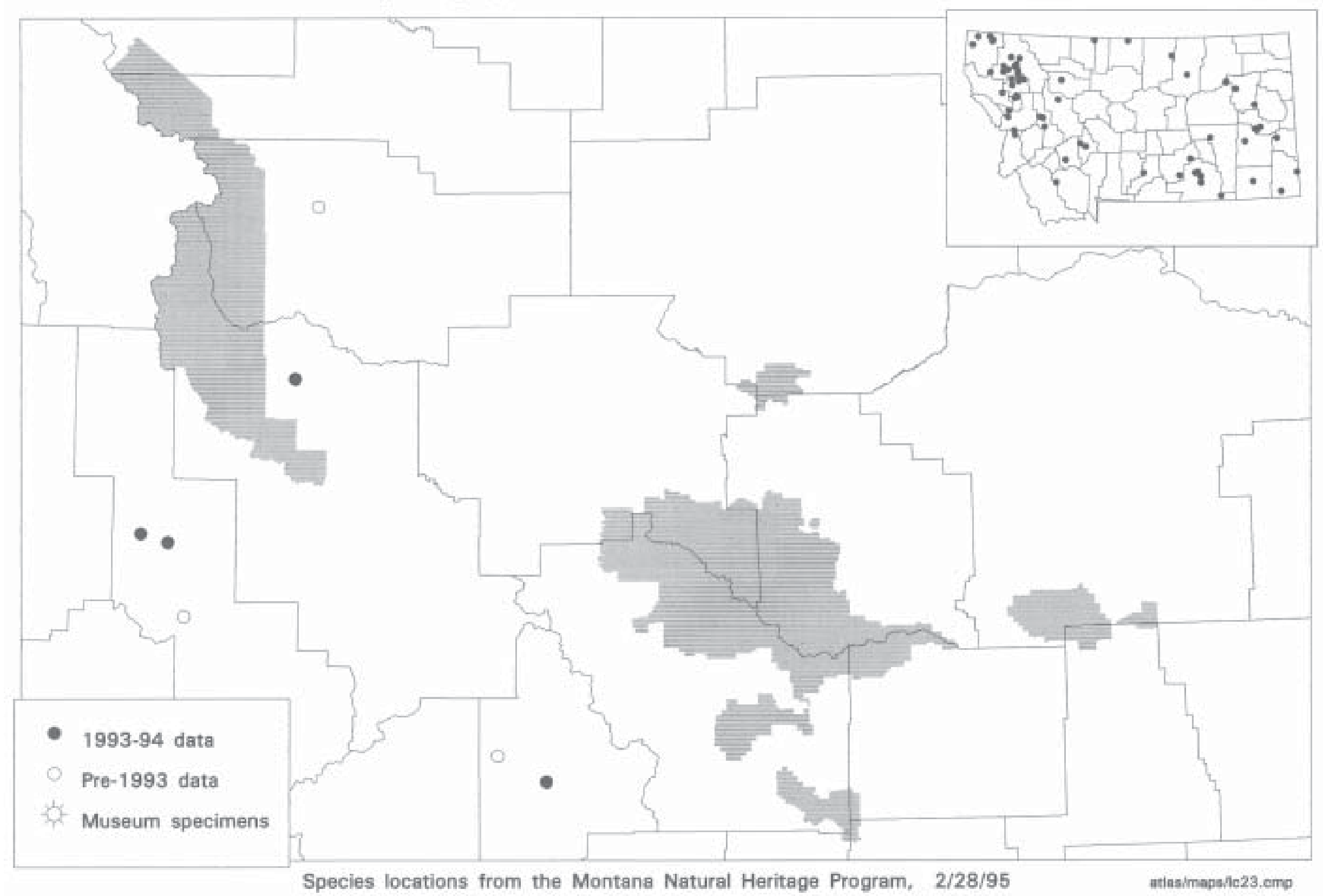




\section{Painted Turtle (Chrysemys picta)}

Description: Adult Painted Turtles have a relatively flat dorsal shell, or carapace, the length of which may reach 9" in females and 7" in males. The background color of the shell may be dark brown, olive, or black. A series of short, irregular yellow lines are often scattered across the shell, and a red and black border forms the outer edge. The ventral shell, or plastron, is red with a centrallylocated yellow and black blotch with edges flaring out along the border of the scutes. The edge of the plastron also has a series of black and yellow blotches. The head, neck, and legs are marked with yellow lines and a red spot appears behind the eye. Very dark colored individuals are occasionally found. Males are distinguished by longer front claws and longer tails with the anus posterior to the margin of the carapace (Ernst et al. 1994).

Eggs and Young: The elliptical, white, soft-shelled eggs are about 28-35 $\mathrm{mm}$ in length and 16-23 mm in width (Ernst et al. 1994). They typically number 6-23 per clutch. Coloration of young Painted Turtles is more vibrant and the shell is not quite as flattened as adults.

Similar Species: None.

Habitat and Habits: Painted Turtles are active during the day and are rarely seen far from ponds, lakes, or the slow-moving water of streams. Adults are primarily herbivorous, feeding on a variety of aquatic plants, but will also scavenge on animal remains. Eggs are usually laid within 10-20 feet of the waterís edge, although some individuals will travel up to $600 \mathrm{~m}$ seeking a suitable site. During egg-laying, the female excavates a hole with her hind feet and deposits the eggs, which are then covered by several inches of dirt. Predation on turtle eggs by raccoons, skunks, etc. is common, and shell fragments are evidence of such activity. Female Painted Turtles may lay more than one clutch of eggs each summer. Young borne of late egg depositions overwinter in the nest and do not emerge until the following spring (Ernst et al. 1994). Once females lay their eggs, they return to the pond, where they can often be seen basking on logs or rocks along with juveniles and males. Painted Turtles are sexually mature at 3-5 years of age and may live to be 30 years or older (Ernst et al. 1994).

Surveying: Although various turtle traps can be used for surveys, visual identification is suitable for presence/absence studies since the three turtle species in Montana are easily distinguished. Basking peaks at different times during the day, depending on season and location; in the northern states and Canada it generally peaks in the morning. Surveys should be done on sunny days with a pair of binoculars. During cold or cloudy weather, turtles tend to remain underwater for long periods and can be missed on a walk-through survey.

Status: Painted Turtles are locally quite common in Montana at lower elevations. They were not found on the L\&CNF, but were seen only a few miles east of the RMRD. There has been some concern about Painted Turtle populations nationally, and whether declines have occurred in Montana is unknown. It should be watched for particularly at lower elevations in ponds in open forest, prairie or shrub-steppe habitat on the L\&CNF. Any animals located should be documented. Montana Natural Heritage Program Rank: G5 S5. 


\section{Occurrences of Trionyx spiniferus on or near the Lewis \& Clark National Forest}

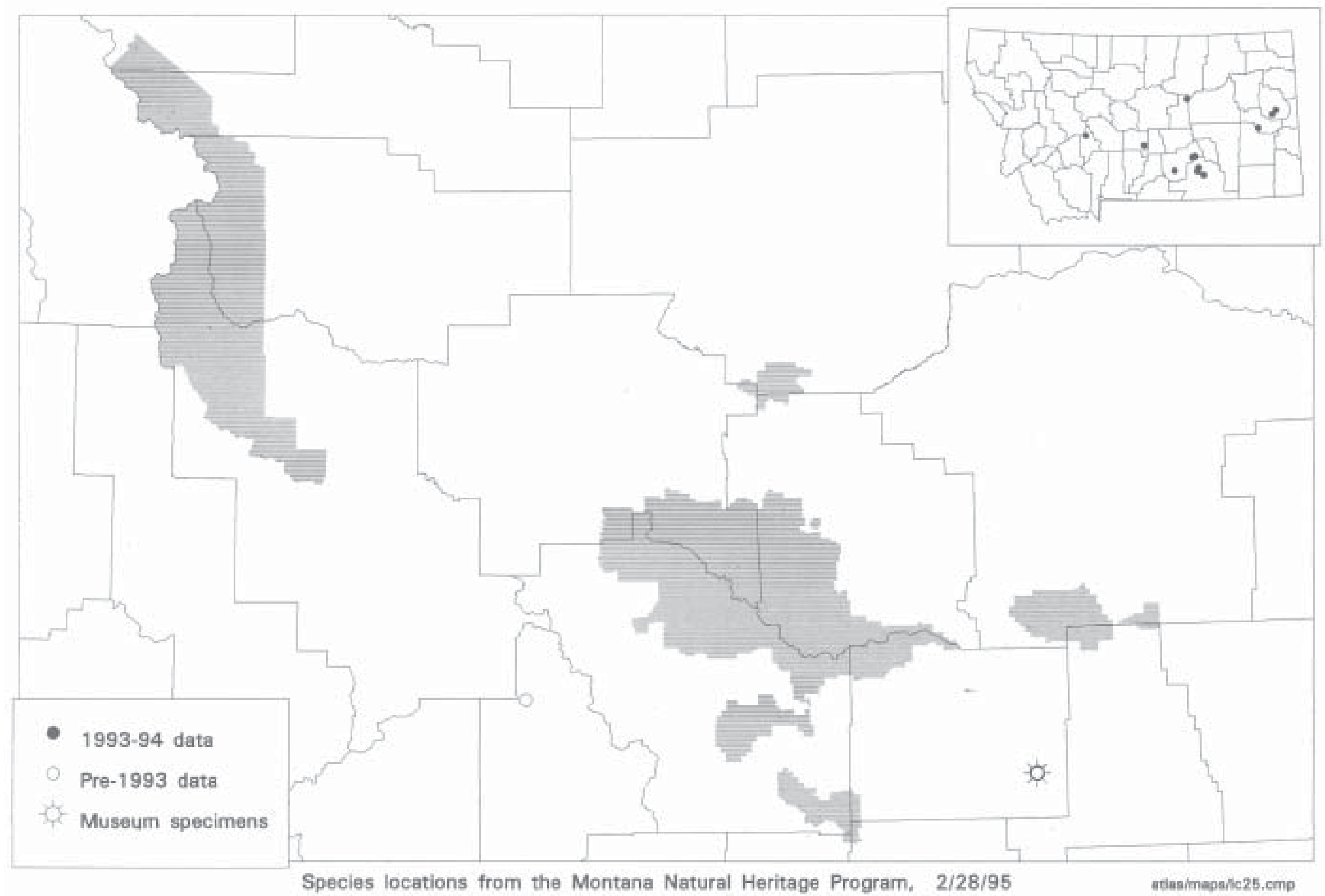


Spiny Softshell (Trionyx spiniferus) (=Apalone spinifera)

Description: Spiny Soft-shells have flexible, leathery shells. The carapace is olive-gray, marked with dark spots. The plastron is white or light cream-colored. Female carapace length is up to 18 inches or more, whereas males are typically 6-8 inches. The nostrils are terminal, allowing this turtle to remain entirely beneath the surface and take air through its ìsnorkel.1.

Eggs and Young: The nest is a flask-shaped excavation containing 4-39 (typically 12-18) hardshelled, spherical, white eggs. The individual eggs range in size from $24-32 \mathrm{~mm}$ in diameter and average about $28 \mathrm{~mm}$. Hatchlings resemble adults and are $30-40 \mathrm{~mm}$ in shell length (Ernst et al. 1994).

Similar Species: None.

Habits and Habitat: Spiny Softshells are active during the day. This highly aquatic turtle is found in rivers or their connecting backwaters with muddy or sandy bottoms. Unlike other Montana turtles, they do not move overland from one water body to another. Mud and sand banks and bars are used for both basking and nesting. Hibernation takes place beneath the water, usually beneath 5-10 cm of bottom substrate (Ernst et al. 1994). The retracted head and neck combines with the profile of the shell to produce a wedge shape, which allows this turtle to escape by literally diving into the bottom mud. If necessary, additional strokes of the legs will completely bury it in the substrate, hidden from view. Food items include fish, crayfish, frogs, toads, aquatic insects, and carrion. Spiny Soft-shells have a surprisingly long, agile neck and can inflict a painful bite. They can be safely handled by grasping the shell on each side between the front and rear legs with the head pointing away from the captor.

Surveying: Although various turtle traps can be used for surveys, visual identification is suitable since the three turtle species in Montana are easily distinguished. A pair of binoculars is helpful and surveys should be done on warm sunny days; basking seldom takes place before 10:00 a.m. (Ernst et al. 1994). During cold or cloudy weather, turtles tend to remain underwater for long periods and can be missed on a walk-through survey. Care should be taken to watch for the snorkel-like nostrils projecting just above the surface of the water.

Status and Distribution: Found mainly in the Yellowstone and Missouri Rivers and their major tributaries. These populations may be separated from each other and are believed to be disjunct form the population in South Dakota (Ernst et al. 1994); they have not been reported from North Dakota (Wheeler and Wheeler 1966). The Missouri River population is known from the tail of Fort Peck Reservoir upstream to the first dam above, and from most of the Mussellshell River; their presence on other tributaries is presently unknown. They have been reported from the Mussellshell River to just southeast of the Little Belt Mountains and should be watched for in the Mussellshell, Judith, and Smith Rivers on the L\&CNF. Any located on the L\&CNF should be documented and reported. Considered a Species of Special Concern in Montana.

Montana Natural Heritage Program Rank: G5 S3. Species of Special Concern. 
Occurrences of Phrynosoma douglasi on or near the Lewis \& Clark National Forest

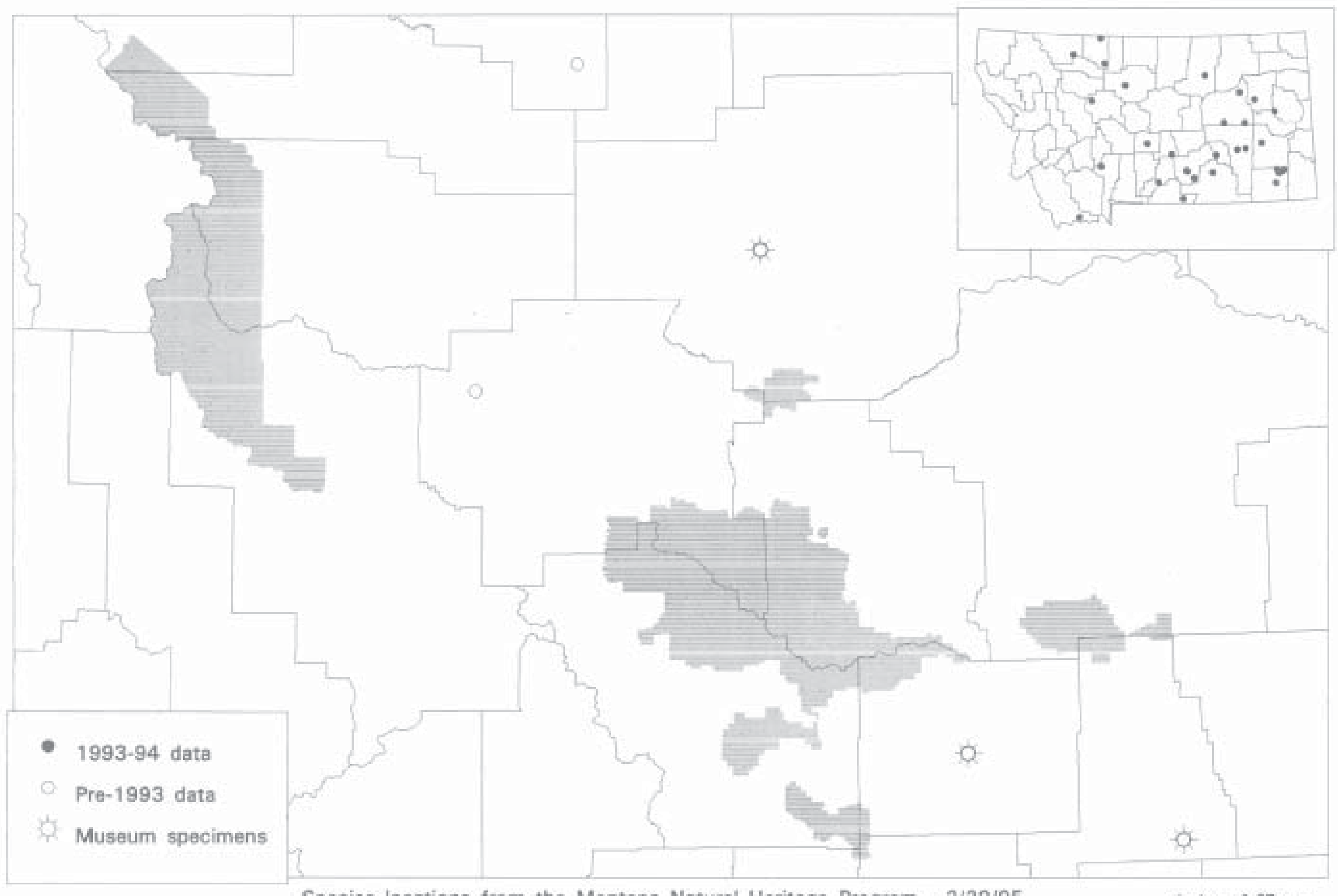

Species locations from the Montana Natural Heritage Program, 2/28/95 
Short-horned Lizard (Phrynosoma douglasi)

Description: The Short-horned lizard has a broad, somewhat flatted body and relatively short limbs and tail. It is generally tan to gray with dark and light spots and blotches; the belly is white. There is a distinctive line of pointed scales along each side and the head has short, blunt ihornsî pointing backward. Adult lizards range from 1.7 - 5.5" in length.

Young: Young are live-born and resemble small adults.

Similar species: None.

Habitat and Habits: The Short-horned lizard is found in a variety of habitats, including dry open forests, grasslands, and sagebrush; the soil is usually loose or sandy. In firmer soil situations it may use the burrows of other animals. It is active during the day, typically with the peak of activity in mid-late morning. A Short-horned Lizard may squirt blood from its eyes when disturbed. Little is known about reproduction in this part of the range; young are born in late summer. Ants are the primary food of the species.

Surveying: They may be surveyed for by slowly walking through appropriate habitat and carefully watching for them; look carefully near ant mounds; this technique has low success with Shorthorned Lizards however. As with many lizards and snakes, they are easily missed. Carefully documented incidental observations may provide the best clues to their distribution. They may be also taken in pitfall or funnel traps in combination with drift fences.

Status: Widely distributed (but apparently localized) in eastern Montana. This species may be vulnerable to collecting for the pet trade and agricultural conversion of native habitats. The Shorthorned Lizard subspecies found in Montana ( $P$. d. brevirostra) is currently a U.S. Fish and Wildlife Service Category 2 Candidate species (U.S. Fish and Wildlife Service 1994). In the vicinity of the L\&CNF it has been found at breaks west of Ulm, Egg Mountain on Nature Conservancy land, north of the Highwood Mountains, and near Harlowton southeast of the Little Belt Mountains. It should be watched for in open pine, prairie, or shrub-steppe habitat with loose or sandy soils at lower elevations on the L\&CNF; any sightings should be documented.

Montana Natural Heritage Program Rank: G5 S4. 
Occurrences of Charina bottae on or near the Lewis \& Clark National Forest

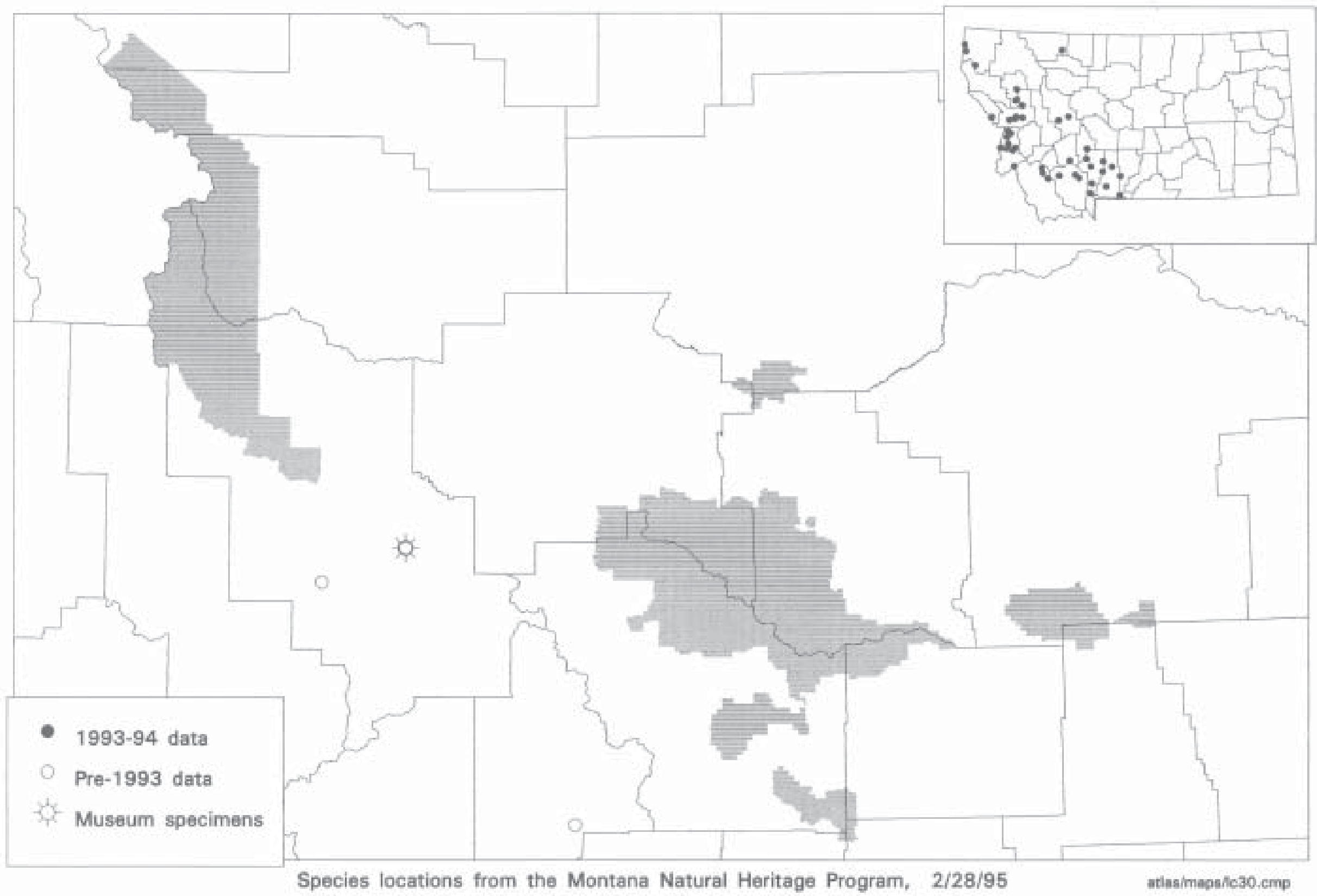




\section{Rubber Boa (Charina bottae)}

Description: The Rubber Boa looks and feels like rubber, hence its name. It is a small snake (14-33" length), stout, and uniformly-colored either brown or green on the dorsal side. The ventral surface is cream to tan in color. The scales are small and smooth, except for those on the head which are enlarged. The tail is short and blunt and the eyes are very small. It is a very slow moving snake which can easily be caught if detected.

Young: Rubber Boas are born alive and young are more tan (or even pinkish) than the adults on both the dorsal and ventral surfaces.

Similar species: The Racer is much quicker and more active, has larger eyes, and a thin, tapered (not blunt) tail.

Habitat and Habits: The Rubber Boa is a secretive, slow-moving, docile snake, usually found under logs and rocks in either moist or dry forest habitats, but rarely in marsh or bog situations. Denning locations are typically in areas with fractured rock; recent data indicates it only moves short distances from its den (Peterson pers. comm). Occasionally this snake is seen sunning itself on a road, trail, or open area, but it is primarily nocturnal. Feeding is primarily on small mice, but also on shrews, salamanders, snakes and lizards. Two to eight young are born alive in late summer or early fall.

Surveying: There are no practical methods for surveying other than systematic searches of a given area rolling over rocks, logs, etc. Driving roads at night, particularly after a rain when the temperature is $>10^{\circ} \mathrm{C}$, may be more effective, especially on roads which follow a stream. Previous sightings are of value in locating general areas of activity and denning sites. Funnel traps may be effective.

Status: Sightings of Rubber Boas are infrequent, but they are widely distributed and probably common throughout western Montana. They were not found during this survey, nor are there historic records of their presence in the L\&CNF. However, they probably do occur throughout the RMRD of the L\&CNF at low to mid-elevations. They should be watched for on the L\&CNF; any sightings should be documented. Of particular interest would be any reports of this species from the Jefferson Division or documentation of any denning sites located.

Montana Natural Heritage Program Rank: G5 S4. 
Occurrences of Coluber constrictor on or near the Lewis \& Clark National Forest

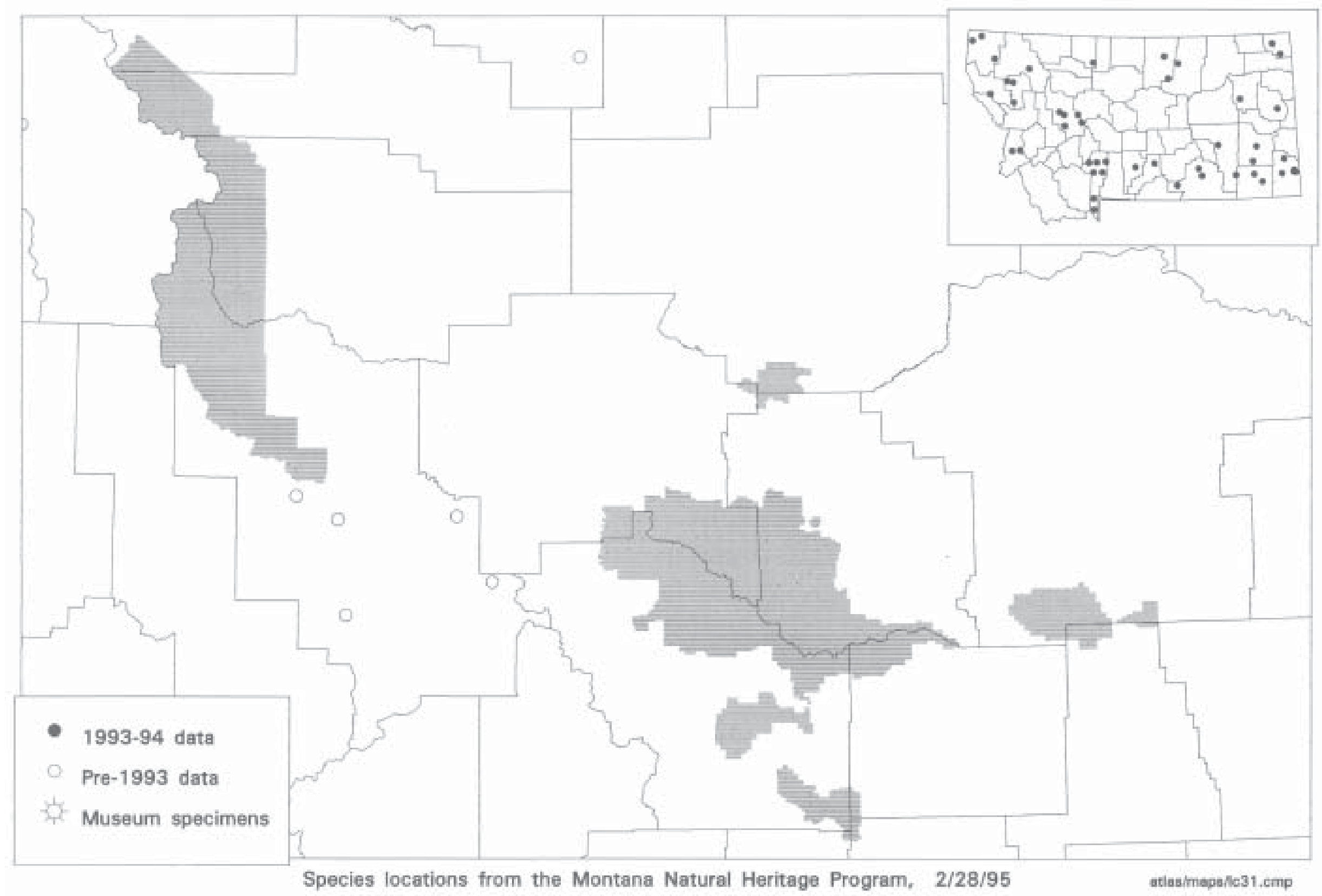




\section{Racer (Coluber constrictor)}

Description: A slender, but moderately long snake, the Racer ranges from 20-65 inches in length. Adult coloration is uniform across the dorsal side but it can vary from a greenish-gray to brown or blue. The ventral side is whitish to pale yellow, the latter color extending onto the upper lip scales and nasal region. The eyes are relatively large. The scales are smooth and the nostril is bordered by two scales.

Young: Snakes (up to about 20") have a much different coloration than the adults consisting of a series of dorsal brown blotches edged with black which run the length of the animal; a row of blotches is also found on each side of the animal extending onto the ventral side.

Similar species: Young Gopher Snakes may be distinguished by the keeled rather than smooth scales of the young Racer. Young Western Hognose Snakes have an upturned nose. Smooth Green Snakes are smaller and colored bright grass-green and whitish below; their nostrils are centered in single scales. Also see Rubber Boa.

Habitat and Habits: The Racer is associated with more open habitats either in shortgrass, shrub-steppe, or forested areas (Hammerson 1982a, Baxter and Stone 1985). It is often found near water and rocks. The Racer is an extremely fast and agile snake. A clutch of perhaps 3-7 eggs is laid in the summer (Stebbins 1985). It preys on insects and small vertebrates such as mice and frogs.

Surveying: They may be surveyed for by slowly walking through appropriate habitat on warm, sunny days and carefully watching for them; this technique is moderately effective for the Racer. However, as with many lizards and snakes, they may easily be missed. Carefully documented incidental observations may provide the best clues to their distribution. They may be also taken in funnel traps with drift fences. Mark-recapture methods offer the best opportunity for determining population status.

Status: The Racer was not seen in this survey nor are there historic records from the L\&CNF. However they are known just to the south of the RMRD and from about 25 miles west of the Little Belt Mountains. They probably do occur on the L\&CNF at low to mid-elevations; any sightings should be documented. Of particular interest would be documentation of any denning sites located. Montana Natural Heritage Program Rank: G5 S5. 
Occurrences of Heterodon nasicus on or near the Lewis \& Clark National Forest

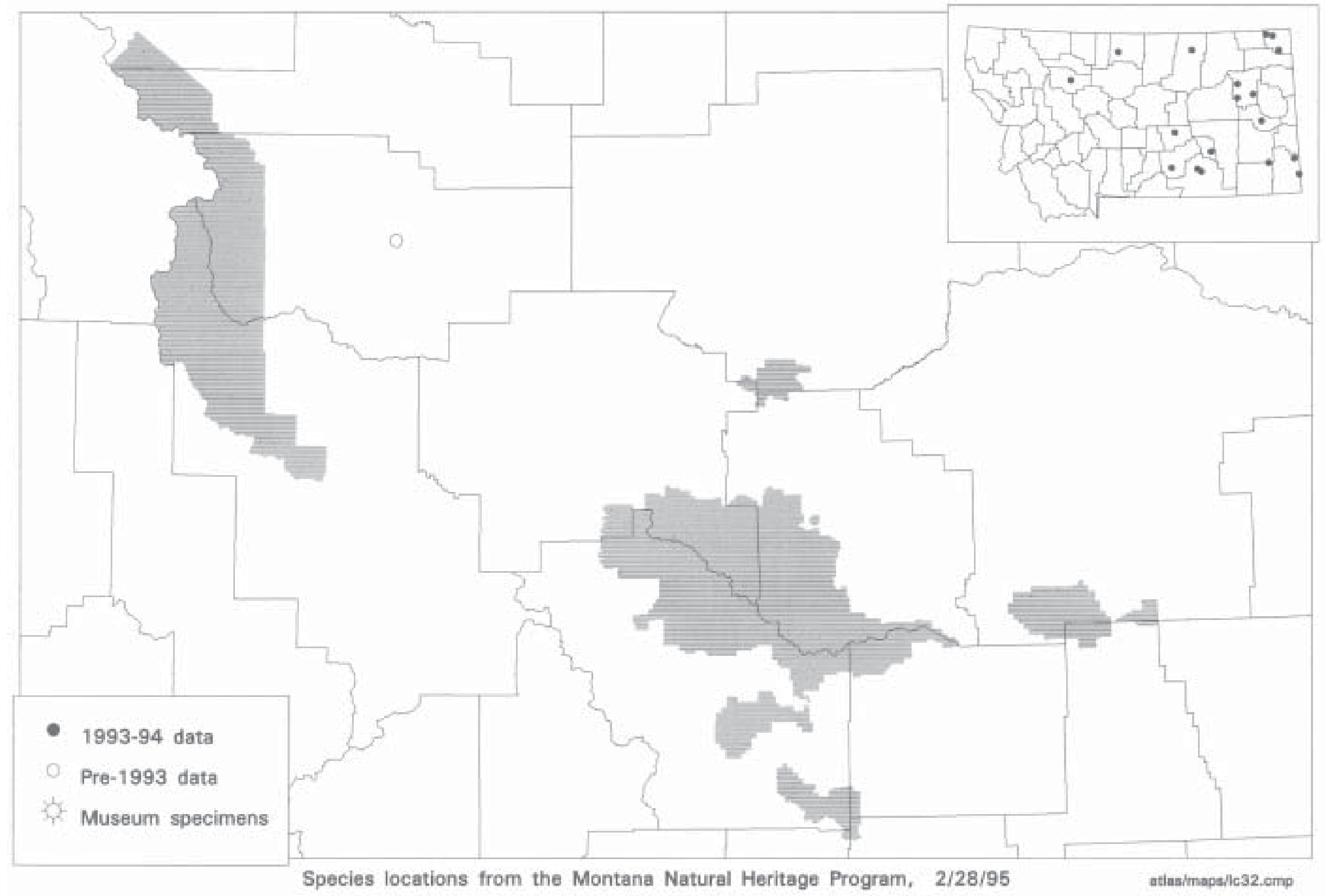




\section{Western Hognose Snake (Heterodon nasicus)}

Description: The Western Hognose Snake is a mid-sized, heavy-bodied snake reaching 32". The dorsal ground color is yellowish- to grayish-brown, with 3 rows of darker brown to black blotches run down the back. The belly is dark gray to black, sometimes checkered. Its nose has a keel on the top and is upturned.

Eggs and Young: Eggs are white and elliptical, with thin, papery shells; length averages $32.5 \mathrm{~mm}$ (26-38 mm) and width $18 \mathrm{~mm}(14-23 \mathrm{~mm})$. Young are 139-197 $\mathrm{mm}$ at hatching and are similar in color and pattern to adults (Platt 1969).

Similar Species: No other Montana snake has a keeled nose. Coloration is similar to both the Gopher Snake, Western Rattlesnake and juvenile Racer.

Habits and Habitat: The Western Hognose Snake is found on the plains of eastern Montana. It seems to prefer arid areas, farmlands and floodplains, and particularly areas of gravelly or sandy, loose soil. The keeled, or shovel-like, nose is thought to help it to dig down to its food, which it finds by smell. Apparently toads are its preferred food, though frogs, insects, and other small animals are also eaten (Platt 1969). It is active primarily during the daylight hours. Little is known of reproduction in Montana. In Kansas, Western Hognose Snakes typically lay clutches of 7-15 eggs (Platt 1969). It is likely that a female will only breed every other year in Montana.

The Hognose is famous for its behavior in the face of a threat. At first it will puff up its neck, as does a cobra, and hiss and strike at its enemy. However, this is all a bluff and very rarely will it actually bite. If this threatening strategy does not work, it will pretend to die. It appears to go into convulsions, writhing on the ground, sticking its mouth in the dirt, and eventually rolling on its back and going into a trance that makes it appear to be dead. If turned right-side-up, it will roll back over and continue its deception. If left alone for a few minutes, it will right itself and continue on its way. The initial aggressive display and basic rattlesnake-like coloration cause many to be killed needlessly by people who mistakenly believe it to be venomous.

Surveying: They may be surveyed for by slowly walking through appropriate habitat and carefully watching for them; timing surveys for warm sunny days enhances sampling success. However, as with many lizards and snakes, they may easily be missed. Carefully documented incidental observations may provide the best clues to their distribution. They may be also taken in pitfall or funnel traps with drift fences. Mark-recapture methods offer the best opportunity for determining population status.

Status: They were not found during this survey, nor are there historic records of their presence in the L\&CNF. However, they may occur on the L\&CNF at low to mid-elevations, particularly in sandy or loose soil areas. The nearest location to the L\&CNF is from central Teton County about 30 miles east of the RMRD. They should be watched for on the L\&CNF; any sightings should be documented. We have relatively few reports of the Western Hognose Snake from Montana. It is collected for the pet trade, and populations may be vulnerable to commercial collectors.

Additionally, since toads are its preferred food, any decline in toad populations would be expected to negatively impact Western Hognose Snakes. Of particular interest would be documentation of any denning sites located.

Montana Natural Heritage Program Rank: G5 S3? Species of Special Concern. 


\section{Occurrences of Pituophis catenifer on or near the Lewis \& Clark National Forest}

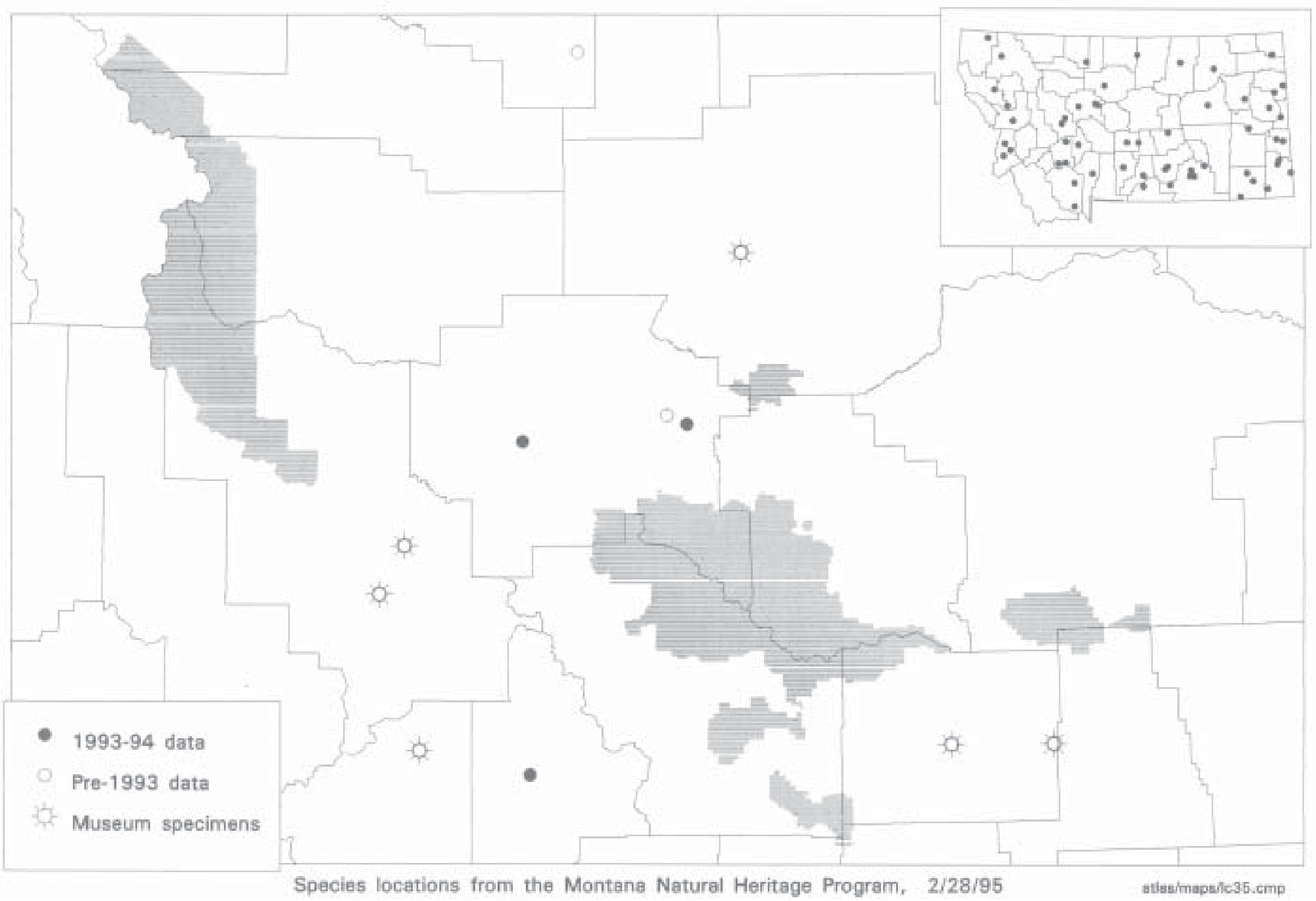


Gopher Snake (Pituophis catenifer [ =melanoleucus])

Description: Montanaís largest snake, the adult Gopher Snake (also called Bullsnake or Pine Snake) can reach a total length of 7 feet, but most specimens seen in western Montana range between 3-5 feet. It is readily recognized by a series of large black to brown blotches which run down the back, and another series along the sides. The blotches, which are set on a yellow background, become more widely spaced and darker towards the tail. The dorsal scales are keeled. There is usually a black band on the head located in front of and extending below the eyes. The ventral coloration is yellow to white, often spotted with black, and the anal plate is undivided.

Eggs and Young: Gopher Snakes lay between 2-24 eggs during the summer months (Hammerson 1982a), and the young resemble the adults in coloration.

Similar species: Young Racers have a black border on dark blotches and the scales are not keeled. Young Western Hognose Snakes have an upturned nose. Western Rattlesnakes have a rattle on their tail and triangular shaped heads.

Habitat and Habits: Gopher Snakes are associated with dry, arid habitats including grassland, shrubsteppe, and open pine forest. They feed on rodents, rabbits and ground dwelling birds, and to a lesser extent on frogs, toads, etc., found around stock ponds and other wetlands. They have a habit of hissing and vibrating the tail when alarmed, often sounding like rattlesnakes. They occasionally climb trees, hence the common name iPine Snake.î

Surveying: Walk-through surveys, done on a regular basis in warm, sunny weather probably give the best results without resorting to trapping techniques. They are most easily found near dens in the spring and fall. Funnel trapping is effective and they may occasionally be found by night driving during the mid-summer. Data can be enhanced by mark-recapture techniques.

Status: The Gopher Snake was not seen in this survey nor are there historic records from the L\&CNF. However they are known from lower elevation areas on the plains adjacent to the forest. They probably do occur on the L\&CNF at low to mid-elevations; any sightings should be documented. Of particular interest would be documentation of any denning sites located.

Montana Natural Heritage Program Rank: G5 S5. 
Occurrences of Thamnophis radix on or near the Lewis \& Clark National Forest

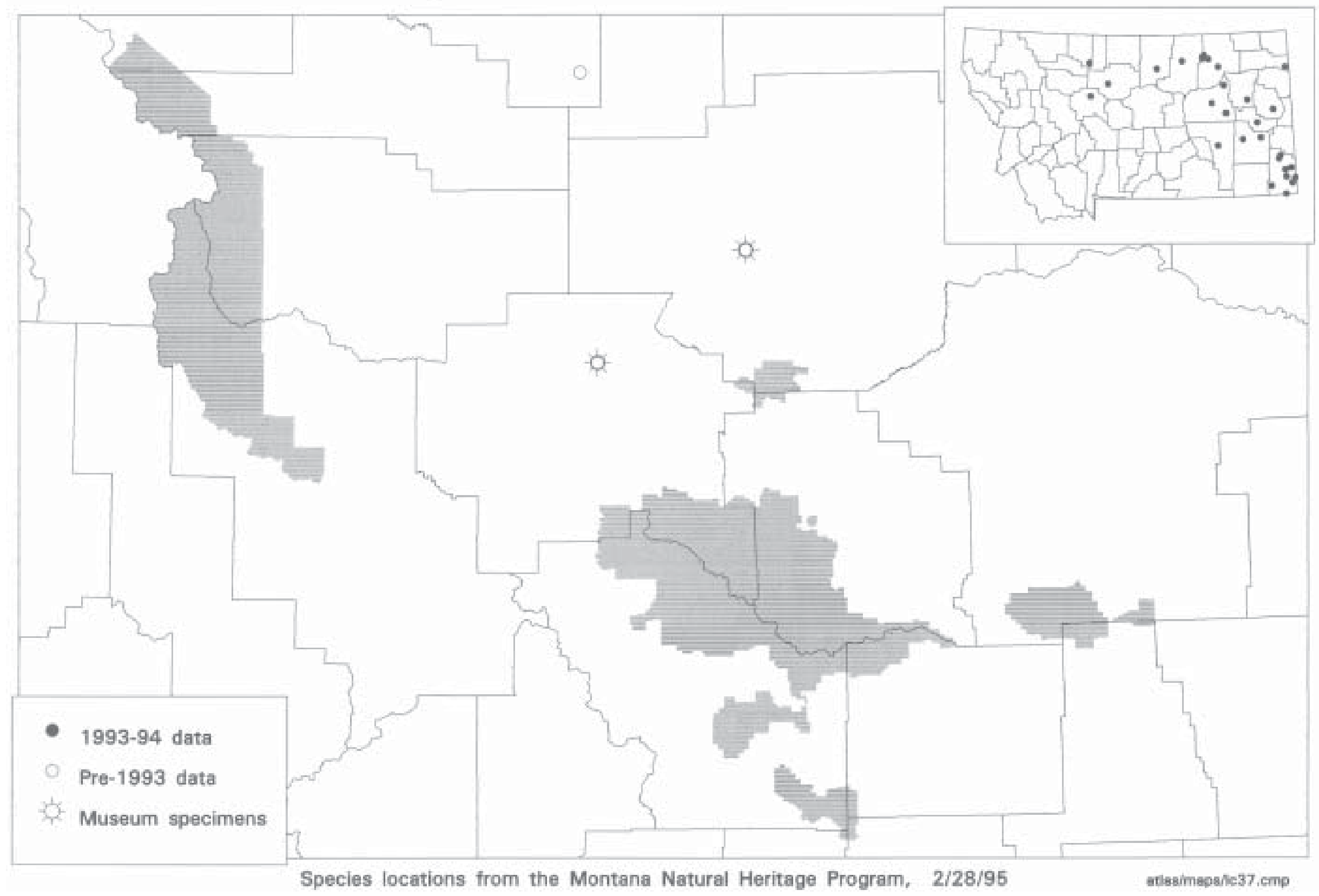


Plains Garter Snake (Thamnophis radix)

Description: The Plains Garter Snake ranges in size from 16-42" in length and has a dorsal background color of olive, brown, or black. It has a prominent orange or yellow dorsal stripe and a greenishyellow stripe on each side located on the $3 \mathrm{rd}$ and 4 th scale rows above the belly scales. It typically has black vertical bars on the upper lips.

Young: Young resemble adults.

Similar species: The other garter snakes found in Montana have the lateral yellow lines on the 2nd and 3 rd scale rows above the belly scales.

Habitat and Habits: The habitat and habits of the Western Terrestrial Garter Snake are similar to those of the Common Garter Snake.

Surveying: Timed sight surveys may be conducted around wetlands and riparian feeding areas or at denning areas where higher concentrations of garter snakes occur; clear mornings may be the best survey times. Much distributional information may come from recording incidental sightings. More intensive research may be done using funnel traps in combination with drift fences. More intensive research and survey projects may use mark-recapture or radiotelemetry techniques.

Status: Found over much of eastern Montana. Its status is unclear due to confusion in the identification of the 3 garter snakes which occur there. In the vicinity of the L\&CNF it has been found near Great Falls and north of the Highwood Mountains. It should be watched for in prairie or shrubsteppe areas at lower elevation of the L\&CNF and any sightings should be well documented with a description written at the time of observation including how radix was distinguished from the other garter snakes. Of particular interest would be documentation of any denning sites located.

Montana Natural Heritage Program Rank: G5 S4. 
Occurrences of Crotalus viridis on or near the Lewis \& Clark National Forest

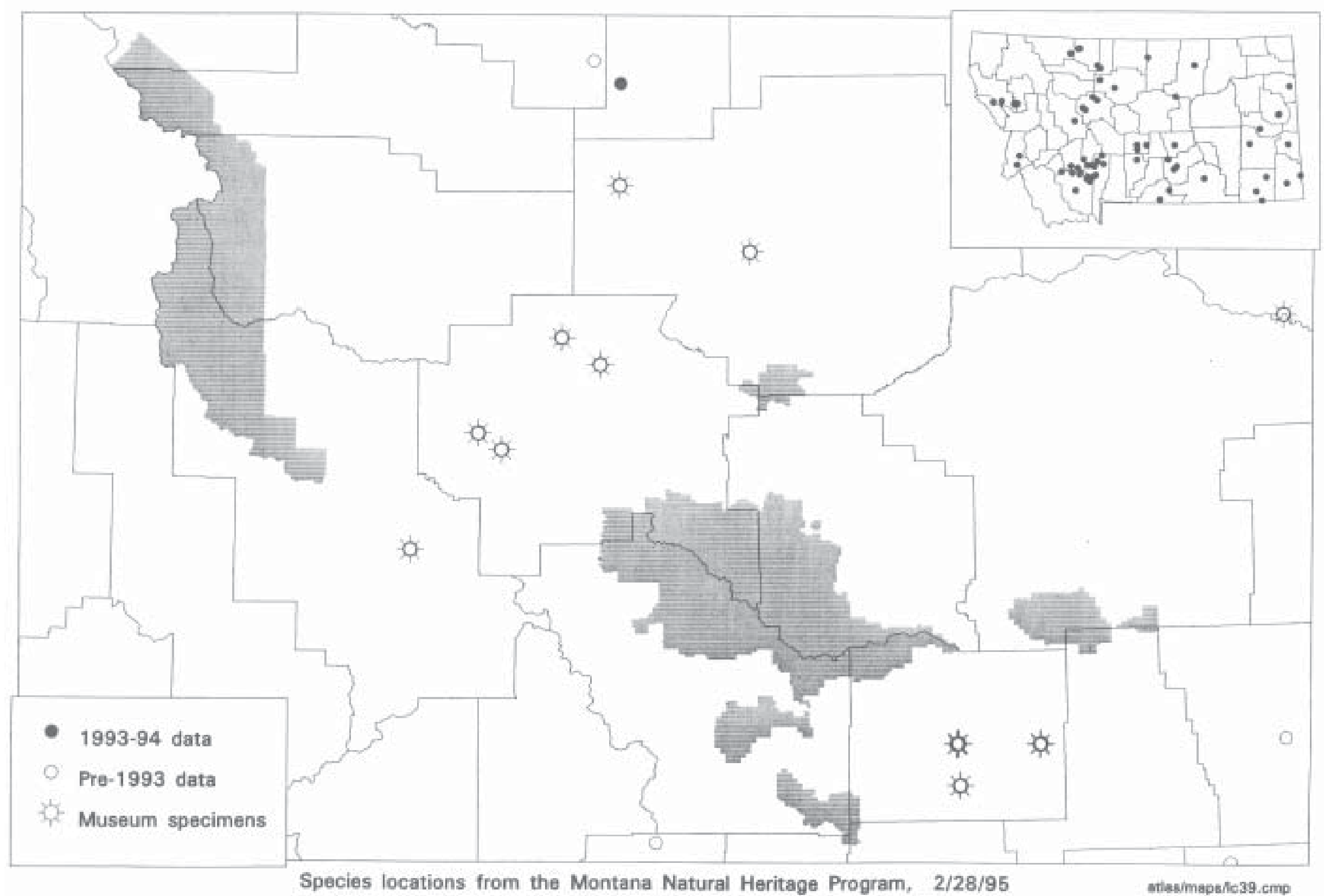




\section{Western Rattlesnake (Crotalus viridis)}

Description: Rattlesnakes have a heat-sensing pit located between the nostril and the eye. The fangs are hollow and hinged, allowing them to be folded back against the roof of the mouth. The head is triangular in shape and blunt-nosed. The eyes are slightly elevated. There are several white lines which run along the side of the head. Adult Western Rattlesnakes have a narrow neck but a stout body with total length ranging from 15-60 inches. The dorsal background color varies from pale green to brown with a series of brown or black blotches edged with a dark and then light line extending the length of the body. The blotches often merge into rings on the tail. There are also blotches on the sides of the body. The ventral side is pale yellow to white and without blotches. The scales are keeled. The tail ends in a rattle which helps to warn potential predators of the snakeís presence. The young have the same color pattern, but are brighter in color than adults.

Similar species: No other snake in Montana has rattles, but see Racer, Gopher Snake and Western Hognose Snake which may have similar color patterns.

Habitat and Habits: The Western Rattlesnake is an inhabitant of more open and arid country but it is also found in Ponderosa pine stands or mixed grass-coniferous forests. It is more likely to be encountered on south-facing slopes and areas of rock outcrops. It is feared and often needlessly killed due to its poisonous bite. Rattlesnakes may den in large numbers, moving up to 7 miles out from the dens during the summer (Peterson, pers. comm.); den sites are most common in southfacing talus slopes. In Wyoming, it is found at elevations of over 8500 feet (Baxter and Stone 1985). Rattlesnakes prey on a variety of animals including mice, ground squirrels, rabbits, amphibians, and other snakes. Females give birth to 4-21 young in Colorado during the summer (Hammerson 1982a).

Surveying: Walk-through surveys on warm sunny days is probably the best method for determining presence/absence; easiest to find near den sites in spring and fall. Funnel traps and night driving are both effective techniques. Mark-recapture methods can be used to determine more precise numbers.

Status: The Western Rattlesnake was not been found in the L\&CNF but is known from lower elevation areas to the north, south, and east. It would most likely be encountered at lower elevations in open habitats on the Jefferson Division. The habit of denning at traditional sites in large numbers makes rattlesnakes vulnerable to commercial collecting or simply killing by fearful people. Observations of Western Rattlesnakes should be reported to document the presence of this species on the L\&CNF; of particular interest would be documentation of any denning sites located.

Montana Natural Heritage Program Rank: G5 S4. 


\section{Rocky Mountain Division Information}

Rocky Mountain Division: Two amphibian species were only found on the Rocky Mountain Division of the L\&CNF: the Long-toed Salamander and Tailed Frog. Both species appeared to be more localized than in areas to the west of the Divide. Additional surveys should be undertaken to determine how widespread these species are; all incidental observations should be recorded. The Rubber Boa is likely to be present due to its proximity to known localities to the south and west; whether it will also be found in the Jefferson Division is unknown.

Other species found during surveys or for which historic locations are known from on the RMRD include the: Western Toad, Western Chorus Frog, Northern Leopard Frog, Spotted Frog, Western Terrestrial Garter Snake, and Common Garter Snake. All of these species are also present on the Jefferson Division. The Western Toad was only found breeding at a single location on the forest; this may be a function of the small amount of sampling or the apparent decline in much of western Montana. The breeding location in the backwater/beaver pond on the Teton River at 7 Lazy P Ranch should be considered for monitoring to see if Western Toads continue to breed there and are successfully reaching metamorphosis. Western Chorus Frogs, though common at lower elevations outside the L\&CNF, apparently are very uncommon and localized within the forest. No Northern Leopard Frogs were seen on surveys. However a museum specimen exists from the iSun River, 5500 feetî; this location information is poor because at 5500 feet the Sun River is split into the major forks. While doing Harlequin surveys, Northern Leopard Frogs should be watched for along the Sun River. Substantial populations of the Spotted Frog were found throughout the RMRD; it was more commonly encountered than any other amphibian or reptile, though ironically it is one of the two C-2 Candidate species present on the L\&CNF. An ideal marsh-pond area below Wood Lake on Wood Creek might be considered for long-term monitoring of Spotted Frogs and Long-toed Salamanders; the area to be monitored would have to be carefully delimited, however, since the area is large. Concerned citizens might be willing to participate in long-term surveys.

Given the low numbers of locations for any amphibians or reptiles on the RMRD, all sightings of any species should be recorded. A possible exception would be for Spotted Frogs; however, breeding locations found should be recorded even for this species until more are known and mapped. Of particular interest would be records of the following species which have not yet been recorded on the District: Tiger Salamander, Great Plains Toad, Plains Spadefoot, Painted Turtle, Short-horned Lizard, Racer, Western Hognose Snake, Gopher Snake, Plains Garter Snake, and Western Rattlesnake. All of these potentially present species are most likely to be seen at low elevations in open habitat.

\section{Jefferson Division Information}

Highwood Mountains: This range is the only Jefferson Division area in which Western Chorus Frogs are known; they were found by Mike Enk in 1994 and had been collected in the 1960s north of the 1994 location. The Western Chorus Frog is the only herp recently recorded from the Highwoods. The 
Western Toad, Northern Leopard Frog, Western Terrestrial Garter Snake, and Common Garter Snake were all collected along Highwood Creek or Arrow Creek in the 1960s but were not relocated during our surveys. Perhaps the best chance of finding the Great Plains Toad on the L\&CNF occurs in the Highwoods, given its known site to the north. Given the meager information available from this range and at least two species (known to be declining) recorded from historic records but not relocated, all sightings of amphibians and reptiles are of interest from this range and should be recorded. Baseline distribution information, particularly for species not yet recorded and breeding sites for known species, is necessary before monitoring sites are chosen.

Little Belt Mountains: Spotted Frogs appeared to be common and widespread in this range. Western Toads have been collected historically, but were not located during our surveys; any sightings of this declining amphibian should be recorded. The Western Terrestrial Garter Snake and Common Garter Snake were the only other herps found during our surveys. Perhaps the best chance of finding the Spiny Softshell on the L\&CNF occurs in the Little Belts in the Smith, Judith, or Mussellshell Rivers. Given the meager information available from this range and at least one species known from historic records but not relocated, all sightings of amphibians (except perhaps Spotted Frogs) and reptiles are of interest and should be recorded. Even for Spotted Frogs any breeding locations found should be recorded. Such baseline distribution information is necessary before monitoring sites are chosen.

Castle Mountains: The Spotted Frog is the only herp known from this range; there is one historic specimen record and the species was also found during our 1994 surveys in beaver ponds in the West Fork of Checkerboard Creek. Tiger Salamander larva were found at the base of the range just north of Lennep offUSFS Lands. Given the meager information available from this range all sightings of amphibians and reptiles are of interest and should be recorded. Baseline distribution information, particularly for species not yet recorded and breeding sites for known species, is necessary before monitoring sites are chosen.

Crazy Mountains: The Spotted Frog was the only herp found during surveys in 1994 and was located in Forest Lake. Western Toads have been collected historically in the Crazy Mountains, but were not located during our surveys; any sightings of this declining amphibian should be recorded. Given the meager information available from this range all sightings of amphibians and reptiles are of interest and should be recorded. Baseline distribution information, particularly for species not yet recorded and breeding sites for known species, is necessary before monitoring sites are chosen.

Big Snowy Mountains: The Western Terrestrial Garter Snake is the only herp known from this range; there are three historic specimen records and this species was found during our 1994 surveys on the shore of Crystal Lake. Given the meager information available from this range, all sightings of amphibians and reptiles are of interest and should be recorded. Baseline distribution information, particularly for species not yet recorded and breeding sites for known species, is necessary before monitoring sites are chosen. 
Little Snowy Mountains: No herps are known from this range; there are no historic specimen records and we did not survey here in 1994. Given the total lack of information available from this range, all sightings of amphibians and reptiles are of interest and should be recorded. This baseline distribution information, particularly for species not yet recorded and breeding sites for known species, is necessary before monitoring sites are chosen. 


\section{RECOMMENDATIONS}

1) All incidental sightings of amphibians and reptiles from the L\&CNF should be recorded and forwarded to the Natural Heritage Program. The single exception being that for the Spotted Frog on the RMRD and Little Belt Mountains, only breeding locations are necessary to record. A half-day training session for biologists (including seasonal employees) and other interested field people in May would raise awareness of this data need and provide the training needed for accurate identification of animals observed. Certainly all Tailed Frogs (larvae and adults) found during fisheries surveys should be recorded; this is the most efficient way to get data on this species. The Tailed Frog is now a USFWS C-2 Candidate.

2) Due to the time constraints and the large area covered in the 1994 survey, it should not be regarded as a definitive index of all the herptiles or their distribution on the L\&CNF. The secretive habits of many amphibians and reptiles, and our lack of knowledge regarding their reproductive behavior makes it difficult to assess their overall status. We recommend that additional surveys be conducted, concentrating on: A) potential Western Toad and Northern Leopard Frog breeding sites; B) lowelevation, xeric habitats (including wetlands within this matrix) for reptiles and plains-dwelling amphibians; C) re-surveying historic amphibian sites; and D) gathering additional distribution information from the isolated ranges on the Jefferson Division.

3) When more breeding locations for amphibians are known, long-term monitoring of typical marshpond habitats should be set up at several sites in each Division in order to evaluate relative numbers and breeding success of the more common species: Long-toed Salamander, Spotted Frog, Western Toad, Western Chorus Frog, Western Terrestrial Garter Snake, and Common Garter Snake. Particular attention needs to be given to any Western Toad and Northern Leopard Frog breeding sites found.

4) Life history and ecology of the amphibians in Montana is poorly known for most species. Longterm monitoring will give us information on timing of and habitat requirements needed for successful breeding.

5) Sightings on L\&CNF lands of the Tiger Salamander, Great Plains Toad, Woodhouseís Toad, Plains Spadefoot, Painted Turtle, Spiny Softshell, Short-horned Lizard, Rubber Boa, Racer, Western Hognose Snake, Gopher Snake, Plains Garter Snake, and Western Rattlesnake would represent first-time occurrences and range extensions, thus it is important to document and record such data. Preferably either photos should be taken or, if appropriate, a specimen collected; at the very least, a description should be written at the time of the observation. 


\section{BIBLIOGRAPHY}

Anderson, M. E. 1977. Aspects of the ecology of the two sympatric species of Thamnophis and heavy metal accumulation within the species. M.S. Thesis, University of Montana, Missoula. 147 pp.

Baxter, G. T. and M. D. Stone. 1985. Amphibians and reptiles of Wyoming. Wyoming Game and Fish Department. Cheyenne, Wyoming. 137 pp.

Bellis, E. D. 1962. The influence of humidity on wood frog activity. Amer. Midl. Nat. 68(1):130 148.

Bergeron, D. No date. Terrestrial wildlife survey, Coal Creek Mine Area, Montana, 19771978 . West. Tech. \& Eng., Inc., Helena.

Bernard, S. R. and K. F. Brown. 1977. Distribution of mammals, reptiles, and amphibians by BLM physiographic regions and A. W. Kuchlerís associations for the eleven Western States.

Black, J. H. 1967. A blue leopard frog from Montana. Herpetologica 23 (4):314 315.

Black, J. H. 1969. The frog genus Rana in Montana. Northwest Sci. 43:191 195.

Black, J. H. 1970. Amphibians of Montana. Mont. Fish \& Game Dept., Pub. No. 1 of Animals of Montana Series.

Black, J. H. 1970. Some aspects of the distribution, natural history and zoogeography of the toad genus Bufo in Montana. M.S. thesis, University of Montana, Missoula.

Black, J. H. 1970. Turtles of Montana. Montana Wildlife, Animals of Montana Series 2:2632.

Black, J. H. 1970. Unusual forms of boreal toads Bufo boreas (Amphibia: Bufonidae) in Glacier National Park, Montana. Proc. Okla. Acad. Sci 50: 127128.

Black, J. H. 1971. The toad genus Bufo in Montana. Northwest Sci. 45: 156162.

Black, J. H. and A. M. Bragg. 1968. New additions to the herpetofauna of Montana. Herpetologica 24:247.

Black, J. H. and R. B. Brunson. 1971. Breeding behavior of the boreal toad Bufo boreas boreas (Baird and Girard) in western Montana. Great Basin Nat. 31: 109113.

Black, J. H. and V. Craig (eds.). 1970. Amphibians of Montana. Montana Wildlife, Animals of Montana Series 1:132.

Bragg, A. N. 1940. Observations on the ecology and natural history of Anura. I. Habits, habitat and breeding of Bufo cognatus say. Amer. Nat. 74:322-438.

Breckenridge, W. J. and J. R. Tester. 1961. Growth, local movements, and hibernation of the Manitoba toad, Bufo hemiophrys. Ecology 42:637 646.

Brodie, E. P., JR. and R. M. Storm. 1970. PLETHODON VANDYKEI. Cat. Amer. Amph. and Rept. 91.12.

Brunson, R. B. 1952. Recent collections of Bufo boreas boreas from western Montana. Proc. Montana Acad. Sci. 11:17 19.

Brunson, R. B. 1955. Check list of the amphibians and reptiles of Montana. Proc. Mont. Academy Sci. 15:2729.

Brunson, R. B. and H. A. Demaree. 1951. The herpetology of the Mission Mountains, Montana. Copeia 1951:306 308.

Bureau of Land Management. 1982. Bloomfield North Fork baseline inventories wildlife. Miles City, MT. 
Bury, R. B., P. S. Corn, K. B. Aubry, F. F. Gilbert and L. L. C. Jones. 1991. Aquatic amphibian communities in Oregon and Washington. U.S.D.A. For. Serv., Pac. NW Res. Station Gen. Tech Rep. PNW-GTR-285:353-362.

Camp, Dresser, and McKee, Inc. 1981. Anaconda Stillwater project 12 month environmental baseline report. Tech. Rpt. for Anaconda Copper Co.

Carey, C. 1993. Hypothesis concerning the causes of the disappearance of boreal toads from the mountains of Colorado. Conservation Biology 7(2):355 362.

Cassirer, E. F., C. R. Groves, and D. L. Genter. 1994. Coeur díAlene salamander conservation assessment. U.S.D.A. Forest Service, Region 1, Missoula, MT. 55 pp.

Censky, E. J. 1986. SCELOPORUS GRACIOSUS. Cat. Amer. Amph. and Rept. 386.1 4.

Clancy, C. and D. Hoth. 1991. [Summary sheet with cover note and annotated Forest map of tailed frog occurrences on the Bitterroot NF.]

Clancy, C. G. 1993. Statewide fisheries investigation. Job completion report to the Fisheries Division of the Montana Department of Fish, Wildlife and Parks.

Clark, T. W., A. H. Harvey, R. D. Dorn, D. L. Genter, and C. Groves, eds. 1989. Rare, sensitive, and threatened species of the Greater Yellowstone Ecosystem. Northern Rockies Conservation Cooperative, Montana Natural Heritage Program, The Nature Conservancy, and Mountain West Environmental Services. 153 pp.

Coen, B. (ed). 1992. Science in Glacier National Park 1991 1992: the annual report of the Cooperative Park Studies Unit Glacier National Park and the University of Montana. 72 pp.

Comer, R. D., P. R. Davis and S. Q. Foster et al. (eds.). 1991. Issues and technology in the management of impacted wildlife. Thorne Ecological Inst., April 8 10, Snowmass, CO. 223 pp.

Conant, R. 1975. A field guide to reptiles and amphibians of eastern and central North America. Second edition. Houghton Mifflin Co., Boston. xvii +429 pp.

Corn, P. S. No Date. Comment on the occurrence of Pseudacris clarki in Montana. Bull. Chi. Herp. Soc. 15(3):77 78.

Corn, P. S. and J. C. Fogelman. 1984. Extinction of montane populations of northern leopard frog (Rana pipiens) in Colorado. J. Herpetol. 18:147-152.

Craig, V. No date. The Axolotl iWalking Fish.î Montana Outdoors? 2 pp.

Daugherty, C. H. 1979. Population ecology and genetics of Ascaphus truei on examination of gene flow and natural selection. Ph.D. thesis, University of Montana, Missoula. 143 pp.

Daugherty, C. H. 1982. Age determination, growth, and life history of a Montana population of the tailed frog (Ascaphus truei). Herpetologica 38:461 468.

Daugherty, C. H. 1982. Age specific movement patterns of the frog Ascaphus truei. Herpetologica 38:468 474.

.Daugherty, C. H. \& A. L. Sheldon. 1982. Age-determination, growth, and life history of a Montana population of the Tailed frog (Ascaphus truei). Herpetologica 38(4):461-468.

Davis, C. V. and S. E. Weeks. 1963. Montana Snakes. Montana Dept. of Fish and Game, Helena, MT, pp.1 10.

Deibert, W. J. 1988. [Letter to D. Genter of 21 June re: observations of tailed frogs (ASCAPHUS TRUEI) in 1985 and 86. Includes map.]

Deibert, William (Jerry). Wildlife biologist, Ninemile Ranger District, Lolo National Forest, 20325 Remount Road, Huson, MT 59846. 406/626 5201. 
Dood, A. R. 1980. Terry Badlands nongame survey and inventory: final report. Montana Department of Fish, Wildlife, and Parks BLM Contract \#YA 512 CT8 217. 70 pp.

Econ, Inc. 1974. Terrestrial wildlife inventory for the Lame Jones and Ismay coal lease tracts. Tech. Rpt.

Ernst, C. H. 1971. CHRYSEMYS PICTA. Cat. Am. Amph. Rep. 106.1 106.4.

Ernst, C. H., J. E. Lovich, and R. W. Barbour. 1994. Turtles of the United States and Canada. Smithsonian Institution Press, Washington, D.C. 578 pp.

Farmer, P. J. and K. Burgess. 1983. Jardine area baseline terrestrial wildlife study, May 15, 1981 May 15, 1982, for Homestake Mining Co. West. Tech. Eng., Helena.

Farmer, P. J. and K. Burgess. 1984. Jardine area baseline terrestrial wildlife study. West. Tech. \& Eng., Helena.

Farmer, P. J. No date. Terrestrial wildlife survey, Pearl area, Montana, June, 1976 June, 1977. Westech, Inc., Helena, MT.

Farmer, P. J., S. B. Heath, D. J. Bergeron and K. L. Scow. 1985. Montana Tunnels project baseline terrestrial wildlife study. Westech, Inc., Helena, MT. for Centennial Minerals, Inc.

Ferguson, D. E. 1961. the geographic variation of AMBYSTOMA MACRODACTYLUM Baird, with description of two new subspecies. Amer. Midland Nat. 65:311 338.

Finch, D. M. 1992. Threatened, endangered, and vulnerable species of terrestrial vertebrates in the Rocky Mountain Region. USFS General Technical Rep. RM 215.38 pp.

Fitch, H. S. 1940. A biogeographical study of the ORDINOIDES artenkries of garter snakes (genus THAMNOPHIS). Univ. Calif. Publ. Zool. 44:1 149.

Fitch, H. S. 1980. THAMNOPHIS SIRTALIS. Cat. Am. Amph. Rep. 270.1 270.4.

Fitch, H. S. 1983. THAMNOPHIS ELEGANS. Cat. Am. Amph. Rep. 320.1 320.4.

Fitch, H. S. and T. P. Maslin. 1961. Occurrence of the garter snake, THAMNOPHIS SIRTALIS, in the Great Plains and Rocky Mountains. University of Kansas Publications, Museum of Natural History 13(5):289 308.

Flath, D. L. 1981. Vertebrate species of special concern. Montana Department of Fish, Wildlife, and Parks. 74 pp.

Flath, D. L. 1984. Vertebrate species of special interest or concern: mammals, birds, reptiles, amphibians, fishes. Wildlife Division, Montana Department of Fish, Wildlife, and Parks. 76 pp.

Fox, W. 1951. Relationships among the garter snakes of the THAMNOPHIS ELEGANS rassenkreis. Univ. California Publ. Zool. 50(5):485 530.

Franz, R. 1970. Additional notes on the Coeur DíAlene Salamander, Plethodon vandykei idahoensis, in Montana. Bull. MD Herpetol. Soc. 6:53 55.

Franz, R. 1970. Egg development of the tailed frog under natural conditions. MD Herpetol. Soc. 6:27 30 .

Franz, R. 1970. Food of larval tailed frogs. MD Herpetol. Soc. 6:49 51.

Franz, R. 1971. Notes on the distribution and ecology of the herpetofauna of northwestern Montana. Bull. Maryland Herp. Soc. 7:1 10.

Franz, R. and D. S. Lee. 1970. The ecological and biogeographical distribution of the tailed frog, Ascaphus truei, in the Flathead River drainage of northwestern Montana. Bull MD Herp. Soc. 6:62 73. 
Gehlbach, F. R. 1967. AMBYSTOMA TIGRINUM. Cat. Am. Amph. Rep. 52.1 52.4.

Genter, D. 1990. The Coeur díAlene Salamander, Montanaís cliff hanger. Montana Outdoors 21(5):15 17.

Genter, D. L., A. Wilson, and E. Simon. 1987. Status report on Coeur díAlene salamander in Montana. Montana Natural Heritage Program, Helena. 101 pp.

Genter, D. L., Wilson, A. G. and E. M. Simon. 1988. Supplementary report on the status of the Coeur díAlene salamander (Plethodon vandykei idahoensis) in Montana. Unpublished report to USDA Forest Service by Montana Natural Heritage Program, Helena. 39 pp. including maps.

Gibbons, J. W., S. S. Novak and C. H. Ernst. 1988. CHELYDRA SERPENTINA. Cat. Am. Amph. Rep. 420.1420 .4$.

Green, D. M., C. H. Daugherty, and J. P. Bogart. 1980. Karyology and systematic relationships of the tailed frog Ascaphus truei. Herpetologica 36(4):346 352.

Groves, C. R. and C. Peterson. 1992. Distribution and population trends of Idaho amphibians as determined by mail questionnaire. Unpubl. Rep. Idaho Dept Fish Game, Boise, Idaho. 16 pp.

Hahn, D. E. 1968. A biogeographic analysis of the herpetofauna of the San Luis Valley, Colorado. M.S. thesis, Univ. Col., Boulder. 103 pp.

Halliday, T., and K. Adler. 1991. Encyclopedia of reptiles and amphibians. Facts on File, New York. $143 \mathrm{pp}$.

Hammer, K. and S. Paulsen. 1989. Coeur díAlene salamander update. EarthFirst 2(2):17 18.

Hammerson, G. A. 1982a. Amphibians and reptiles in Colorado. Colorado Division of Wildlife, Denver. vii $+131 \mathrm{pp}$.

Hammerson, G. A. 1982b. Bullfrog eliminating leopard frogs in Colorado? Herpetol. Rev. 13:115 116.

Haynes, C. M. and S. D. Aird. 1981. The distribution and habitat requirements of the wood frog (Ranidae: Rana sylvatica LeConte) in Colorado. Col. Div. Wildl., Wildl. Res. Section Spec. Report 50. $29 \mathrm{pp}$.

Hebard, W. B. and R. B. Brunson. 1963. Hind limb anomalies of a western Montana population of the pacific tree frog, HYLA REGILLA. Copeia, No. 3, pg. 570571.

Heyer, W. R., M. A. Donnelly, R. W. McDiarmid, L. C. Hayek, and M. S. Foster (eds.). 1994. Measuring and monitoring biological diversity: Standard methods for amphibians. Smithsonian Institute Press, Washington, D.C. 364 pp.

Hollenbeck, R. R. 1976. Movements within a population of Rana pretiosa pretiosa Baird and Girard in South Central Montana. Wyo. Acad. Sci. J. 8(1):72 73.

Holroyd, G. L., G. Burns and H. C. Smith (eds). 1991. Proceedings of the second endangered species and prairie conservation workshop. Provincial Museum of Alberta, Nat. Hist. Occ. Pap. 15. 284 pp.

Hunnicutt, M. 1990. [1990 monitoring report for Plethodon idahoensis sites on the Kootenai NF.] 6 pp. Jellison, W. L. and J. H. Black. 1970. Tularemia in Montana and turtles of Montana. Mt. Wildlife, Nov. 1970. Mont. Fish \& Game Dept. 
Kerfoot, W. C. 1968. Geographic variability of the lizard, SCELOPORUS GRACIOSUS Baird and Girard, in the eastern part of its range. Copeia 1968:139152.

Kerr, R. 1989. Summary of 1989 monitoring of the Coeur díAlene salamander (Plethodon idahoensis) in western Montana. Unpublished report for Montana Natural Heritage Program. 7 pp.

Koonz, W. H. 1993. Amphibians in Manitoba. pp. 273 275. IN: Holroyd, G. L., H. L. Dickson, M. Regnier and H. C. Smith (eds). Proceedings of the Third Prairie Conservation and Endangered Species Workshop. Provincial Museum of Alberta, Nat. Hist. Occ. Pap. 19.384 pp.

Lais, P. M. 1976. Gerrhonotus coeruleus. Cat. Amer. Amphib. Reptiles 178.1 178.4.

Leonard, W. P., H. A. Brown, L. L. C. Jones, K. R. McAllister and R. M. Storm. 1993. Amphibians of Washington and Oregon. Seattle Audubon Soc., Seattle, Washington. 168 pp.

Liebelt, J. 1984. Montanaís reptiles: more than meets the eye. Ravalli Republic, [Hamilton, MT] Feb. 29, 1984.

Lynch, J. E. 1984. Reproductive ecology of Plethodon idahoensis. M.S. Thesis, University of Idaho, Moscow. 59 pp.

Lynch, J. E., Jr. and R. L. Wallace. 1987. Field observations of courtship behavior in Rocky Mountain populations of Van Dykeís Salamander, Plethodon vandykei, with a description of its spermatophore. J. Herpet. 21:337 340.

Mackie, R. J. and G. L. Dusek. 1993. A bibliography of Montana wildlife literature through 1992, DRAFT. Wildlife Management Programmatic Environmental Impact Statement Project, Montana Department of Fish, Wildlife, and Parks. 280 pp.

Manno, S. 1992. The reptiles and amphibians of Lolo National Forest. Lolo Natl. For. pamphlet. 9 pp.

Manville, R. H. 1957. Amphibians and reptiles of Glacier National Park, Montana. Copeia 1957:308 309.

Martin, P. R. 1980. Terrestrial wildlife habitat inventory in southeastern Montana. MT Dept. of Fish, Wildlife and Parks and BLM.

Martin, P. R. 1980. Terrestrial wildlife inventory in selected coal areas of Montana. MT. Dept. of Fish, Wildlife and Parks and BLM.

Martof, B. S. 1970. RANA SYLVATICA. Cat. Am. Amph. Rep. 86.1 86.4.

Matthews, W. C. 1981. Broadus Pumpkin Creek baseline inventory wildlife. BLM, Miles City, MT.

McAllister, K. R., W. P. Leonard, and R. M. Storm. 1993. Spotted frog (Rana pretiosa) surveys in the Puget Sound trough of Washington, 1989-1991. Northw. Nat. 74:10-15.

McEneaney, T. and J. Jensen. 1974. The reptiles and amphibians of the Charles M. Russell National Wildlife Refuge, 1974. Unpubl. mimeo. 3 pp.

Metter, D. E. 1967. Variation in the Ribbed frog Ascaphus truei Stejneger. Copeia 1967(3):634-649.

Micken, L. 1968. Some summer observations on the tiger salamander, Ambystoma tigrinum, in Blue Lake, Madison County Montana. Proc. Mont. Acad. Sci. 28:77 80.

Micken, L. 1971. Additional notes on neotenic Ambystoma tigrinum melanostictum in Blue Lake, Madison County, Montana. Proc. Mont. Acad. Sci. 31:62 64. 
Middendorf, L. J. 1957. Observations on the early spring activities of the western spotted frog (Rana pretiosa ) in Gallatin County, Montana. Proc. Mont. Acad. Sci. 17:55 56.

Miller, J. D. 1975. Interspecific food relationships of Anurans in northwestern Montana and fluoride accumulation in amphibians and reptiles in northwestern Montana. M.S. Thesis, U. of Mont., Missoula. 105 pp.

Miller, J. D. 1978. Observations on the diet of Rana pretiosa, Rana pipiens, and Bufo boreas from western Montana. Northw. Sci. 52:243 249.

Mittleman, M. B. 1948. American Caudata. II. Geographic variation in AMBYSTOMA MACRODACTYLUM. Herpetologica 4:81 95.

Mittleman, M. B., and G. S. Myers. 1949. Geographic variation in the ribbed frog, ASCAPHUS TRUEI. Proc. Biol. Soc. Washington 62:57 68.

Montana Department of State Lands and U. S. Office of Surface Mining. 1982. Final EIS, Western Energy Companyís Rosebud Mine Area C, Block 1.

Montana Department of State Lands. No date. Draft EIS, proposed plan of mining and reclamation, Zortman Mining Company and Landusky Mining Company, Phillips County, MT.

Montana Natural Heritage Program. 1987. Status report on the Coeur díAlene Salamander (Plethodon idahoensis) in Montana. Unpublished report for USDA, Forest Service, Montana Natural Heritage Program, Helena. 98 pp.

Mosimann, J. E. and G. B. Rabb. 1952. The herpetology of Tiber Reservoir Area, Montana. Copeia 1952:23 27.

Mueller, C. F. 1969. Temperature and energy characteristics of the sagebrush lizard (Sceloporus graciosus) in Yellowstone National Park. Copeia 1969:153 160.

Mueller, F. C. and R. E. Moore. 1969. Growth of the sagebrush lizard, Sceloporus graciosus, in Yellowstone National Park. Herpetologica 25:35 38.

Nelson, D. J. 1948. Lampropeltis triangulum gentilis in Montana. Herpetologica 4:170.

Nelson, D. J. 1950. Lampropeltis triangulum gentilis in Montana. Herpetologica 6:41.

Nussbaum, R. A., E. D. Brodie, Jr. and R. M. Storm. 1983. Amphibians and reptiles of the Pacific Northwest. Univ. Press of Idaho. 332 pp.

Olson Elliott and Associates. 1979. Environmental impact of the northern tier pipeline in Montana. Tech. Report prepared for Montana Department of Natural Resources and Conservation.

Olson Elliott and Associates. 1980. Terrestrial wildlife inventory, Montco wildlife study area. Tech. Report for Montco, Billings, MT.

Ortenburger, A. I. 1921. An eastern record and note on CHARINA BOTTAE (Blainville). Copeia 100:84.

Peterson, C. R., E. D. Koch and P. S. Corn. 1992. Monitoring amphibian populations in Yellowstone and Grand Teton National Parks. Unpubl. Report to Univ. Wyo. Natl. Park Serv. Res. Center. 37 pp.

Phillips, K. 1990. Where have all the frogs and toads gone? BioScience 40:422-424.

Platt, D. R. 1969. Natural history of the Hognose Snakes Heterodon platyrhinos and Heterodon nasicus. Univ. Kan. Publ., Mus. Nat. History 18(4):253-420.

Reel, S. 1989. Vest pocket preserves. Montana Outdoors 20(2):27 29. 
Reel, S., L. A. Schassberger, and W. Ruediger. 1989. Caring for our natural communities: Region 1 threatened, endangered and sensitive species program. USDA, USFS, Northern Region, Missoula, Montana.

Reichel, J. D. in prep. Preliminary amphibian and reptile survey of the Custer National Forest: 1994. Montana Natural Heritage Program.

Reichel, J. D. and D. L. Flath. 1995. Identification guide to the amphibians and reptiles of Montana. Montana Outdoors: in press.

Rodgers, T. L., and W. L. Jellison. 1942. A collection of amphibians and reptiles from western Montana. Copeia 1942:10 13.

Scow, K. L. 1978. Terrestrial wildlife survey, Zortman and Landusky areas, Little Rocky Mountains, MT. Tech. Rpt. for Zortman and Landusky Mining Co., Inc., by Westech, Inc.

Smith, H. M. 1978. A guide to field identification Amphibians of North America. Golden Press, New York.

Smith, H. M. and E. D. Brodie, Jr. 1982. Reptiles of North America. Golden Press, NY. 240 pp.

Society for Northwestern Vertebrate Zoology. 1993. Annual meeting: amphibians in the Northwest. Held in Astoria, Ore, 1820 March 1993.

Stebbins, R. C. 1985. A field guide to western reptiles and amphibians. Second edition. Houghton Mifflin Co., Boston. xiv +336 pp.

Stewart, G. R. 1977. CHARINA, C. BOTTAE. Cat. Am. Amph. Rep. 205.1 205.2.

Stuart, L. C. 1930. An extension of the range of COLUBER CONSTRICTOR MORMON (Baird and Girard). Copeia 1930:44.

Sweet, S. S. and W. S. Parker. 1990. PITUOPHIS MELANOLEUCUS. Cat. Am. Amph. Rept. 474.1 474.8.

Tanner, W. W. 1988. EUMECES SKILTONIANUS. Cat. Am. Amph. Rep. 447:1 4.

Teberg, E. K. 1963. An extension into Montana of the known range of the salamander Plethodon vandykei idahoensis. Herpetologica 19:287.

Teberg, E. K. 1965. Range extensions of the salamander Plethodon vandykei idahoensis. Copeia 1965:244.

Thompson, L. S. 1982. Distribution of Montana amphibians, reptiles, and mammals. Montana Audubon Council. 24 pp.

Timken, R. No date. Amphibians and reptiles of Beaverhead National Forest. Unpubl. mimeo. 16 pp.

Timkin, R. L. and D. G. Dunlap. 1965. Ecological distribution of the two species of Bufo in southeastern South Dakota. Proc. S. D. Acad. Sci. 44:113-117.

Turner, F. B. 1958. Life history of the western spotted frog in Yellowstone National Park. Herpetologica 14:96 100.

Turner, F. B. 1960. Population structure and dynamics of the western spotted frog, Rana p. pretiosa Baird and Girard, in Yellowstone Park, Wyoming. Ecol. Monogr. 30(3):251 278.

Turner, F. F. and P. C. Dumas. 1972. RANA PRETIOSA. Cat. Amer. Amph. and Rept. 119.1 119.4.

U.S. Fish and Wildlife Service. 1993. Endangered and threatened wildlife and plants: Finding on petition to list the spotted frog. Fed. Register 58(87):27260 27263. 
U.S. Fish and Wildlife Service. 1994. Endangered and Threatened Wildlife and Plants; Animal candidate review for listing as Endangered or Threatened species. Fed. Reg. 59(219):5898259028.

U.S. Forest Service and Montana Department of State Lands. 1985. Jardine joint venture project.

U.S. Forest Service and Montana Department of State Lands. 1986. Jardine joint venture project, final EIS.

U.S. Forest Service and Montana Department of State Lands. No date. Draft EIS, proposed plan of mining and reclamation, Troy Project, Asarco, Inc., Lincoln County, MT, vol. I.

U.S. Geological Survey and Montana Department of State Lands. 1979. Draft, proposed mining and reclamation plan, Pearl Mine, Big Horn County, MT.

U.S. Geological Survey and Montana Department of State Lands. No date. Draft environmental statement, proposed mining and reclamation plan, Spring Creek Mine, Big Horn County, MT.

VTN. No date. Second yearís analysis of terrestrial wildlife on proposed mine access and railroad routes in southern Montana and northern Wyoming, March 1979 February 1980. Tech. Rep. prepared by VTN Wyoming, Inc., for Shell Oil Co.

Webb, R. G. 1962. North American soft shelled turtles (Family Trionychidae). Univ. Kan. Publ., Mus. Nat. Hist. 13:429 611.

Webb, R. G. 1973. TRIONYX SPINIFERUS. Cat. Amer. Amph. and Rept. 140.14.

Werner, J. K. 1974. Phrynosoma douglassi brevirostre. Herp Review 5(1): 20.

Werner, K. and J. D. Reichel. 1994. Amphibian and reptile survey of the Kootenai National Forest: 1994. Montana Natural Heritage Program. 105 pp.

Westech, Inc. [Western Technology and Engineering]. 1981. The effects of the Tongue River Railroad on terrestrial wildlife. Technical Report for Tongue River Railroad Co.

Westech, Inc. [Western Technology and Engineering]. 1982. Results of Phase one, step one, Little Rockies Project. Tech. Rpt. for Meridan Land and Mineral Co.

Westech, Inc. [Western Technology and Engineering]. 1982. Wildlife reconnaissance, Cypress International Yellowstone Mine. Prepared for Hydrometrics, Inc.

Westech, Inc. [Western Technology and Engineering]. 1987. Valley View Hills: baseline easement report. The Nature Conservancy, Big Sky Field Office, Helena, MT. 44 pp. plus appendices.

Westech, Inc. [Western Technology and Engineering]. No date. Preliminary wildlife reconnaissance, Ruby and Little Ben mine areas, Little Rocky Mountains, Montana. Technical Report for Zortman and Landusky Mining Companies.

Western Ecological Services Co. 1983. Wildlife inventory of the Knowlton known recoverable coal resource area, MT. Prep. for USDI, BLM Cont. No. VA 553 RFP2 1027.

Western Ecological Services Co. 1983. Wildlife inventory of the Southwest Circle known recoverable coal resource area, MT. Prepared for U.S. Department of the Interior, BLM. Contract YA 553 RFP2 1027.

Wheeler, G. C. and J. Wheeler. 1966. The amphibians and reptiles of North Dakota. University of North Dakota, Grand Forks. 103 pp.

Wilson, A. G. and J. H. Larsen Jr. 1988. Activity and diet in seepage-dwelling Coeur díAlene salamanders (Plethodon vandykei idahoensis). Northwest Science 62(5):211-217. 
Wilson, A. G., E. Simon, and J. H. Larsen, Jr. 1989. Range extension for the Coeur díAlene salamander, PLETHODON VANDYKEI IDAHOENSIS, to the Canada United States border. Canadian Field Nat. 103:93 94.

Wilson, L. D. 1978. COLUBER CONSTRICTOR. Cat. Am. Amph. Rep. 218.1 218.4.

Yoffe, E. 1992. Silence of the frogs. New York Times Magazine 13 Dec 1992:36 39, 64 66, 76. 


\title{
APPENDIX 1.
}

\section{DATA SHEETS USED FOR}

\author{
AMPHIBIAN AND REPTILE
}

SURVEYS AND OBSERVATIONS 
AMPHIBIAN SURVEY DATA SHEET: INSTRUCTIONS This data sheet is designed to facilitate quick recording of data from field surveys of amphibians and their habitats. It appears complex and intimidating, but actually can be completed in a short amount of time after a minimum amount of training. Many variables require only the correct choice to be circled, and the remaining variables are numerical and easy to determine. The data sheet is divided into four sections, divided by double lines. Each section describes a cohesive set of variables. In addition the back of the sheet includes a grid for a rough sketch of the site and space for additional comments. The map is optional, but the future value of the data is enhanced if it is supplied.

SECTION 1 - LOCALITY These data are essential. Many amphibian surveys have been hampered by the inability to relocate exact locations in the historical record. Some of this information can be completed in the office after the survey.

DATE: Use the format DD-MMM-YY (e.g., 05-APR-92).

BEGIN TIME: List the time survey of habitat for amphibians began in 24 hour format.

END TIME: List the time the survey ended in 24 hour format. (The total time (END TIME - BEGIN TIME) should refiect only the amount of time spent searching for amphibians. Total time plus number of observers may be used to assess relative abundance)

OBSERVERS: List names or initials of all persons involved in searching.

LOCALITY: Describe the specific geographic location of the site. Use air distance in two directions (e.g., $5 \mathrm{~km} \mathrm{~N}$ and $7.5 \mathrm{~km} \mathrm{~W}$ ) of a map landmark that likely will not change (distance from a large town or city is not all that helpful).

STATE: Use the 2-letter abbreviation.

COUNTY:

MAP NAME: List the name of the U.S.G.S. quadrangle or other map used to locate the site.

OWNER: List the public land manager (e.g., Roosevelt Nat. Forest or Rocky Min NP), or name of the owner if the site is on private land (listing the owner's name will make it clear that you did not trespass to survey the site).

ELEVATION: Circle the scale used; meters are preferred.

T: township R: range S: section

SECTION DESCRIPTION: Describe the location of the site within the section (e.g. SE $\%$ or NE $\%$ of SE $\%$ )

UTM ZONE, NORTHING, EASTING: Universal Transverse Mercator coondinates are preferred over longitude and latitude The UTM zone is listed on newer topographic maps. If you are using a map without the UTM grid, substitute latitude for Northing and longitude for Easting.

SECTION 2 - SPECIES DATA List all amphibian species observed. If garter snakes are seen, list them here also.

SPECIES: Use the scientific name. Convenient shorthand is to use a 4-letter code made up of the first 2 letters of the genus and species (e.g., Rana sylvatica would be RASY).

ADULTS/JUVENILES: Indicate presence with a check, but numbers seen are more valuable data

CALLING?: Circle $Y$ if frogs are vocalizing in a brecding chorus, of if a breeding aggregation of species that don't call (c.g., Bufo boreas) is observed.

TADPOLES/LARVAE: Same as for aduits/juveniles

EGG MASSES: Same as above. Numbers of egg masses are especially valuable data. If possible describe the developmental stage of eggs in the space for additional notes on the back of the form.

METHOD: Circle how observations were made: VISUAL/AURAL ID - species identified without picking it up, either by sight or by recognition of the breeding call HAND COLLECTED - animal was picked up and identified in the field (higher confidence than visual id); DIP NET/SEINE - the usual method of collection for larvae; TRAPPED - minnow-type traps are also used for larvac; VOUCHER COLLECTED? - circle yes or no (woucher specimens are recommended for every site, especially if identification is uncertain and for larvae). Indicate voucher status in addition to method used.

FISH PRESENT?: If yes, list species if you can. Circle the question marks if you are not certain, but suspect that fish are present. ENTIRE SITE SEARCHED?: If no, list either the meters of shoreline or the area $\left(m^{2}\right)$ of habitat (e.g., amount of wet meadow) searched.

SECTION 3 - PIIYSICAL AND CIIEMICAL DATA Water chemistry data are difficult to collect accurately without thorough planning and quality equipment; these data are optional. Weather data are important for determining the quality of the obserwations (e.g., was an absence of amphibians due to observations made during a blizzard?)

WEATHER, WIND: Indicare atmospheric conditions

AIR TEMPERATURE: Take at chest height in shade. The Celsius scale is preferred.

WATER TEMPERATURE: Take 1 mete from margin and at $2 \mathrm{~cm}$ depth, or where egg masses are observed.

COLOR: This is a qualitative assessment of whether the water clear or tea-colored from organic (humic) acids.

TURBIDITY: This is a qualitative assessment of whether the water clear or clouded from suspended particulate matter.

SECTION 4 - HABITAT DESCRIPTION These data are important for developing hypotheses to explain changes in abundance of amphibians. This section needs to be filled out only once for each site (a reasonable amphibian survey should include at least $2-3$ visits to each site in one season).

ORIGIN: Decide whether the lake is a natural geologic formation or man-made. Bodies of water enlarged by a dam are problematic List them as man-mada, but add an explanation in the space for additional notes on the back of the form.

DRAINAGE: Circle whether the site has permanent drainage, no drainage, or occasional drainage. Determining the potential for occasional drainage requires judgement. Look for clues in the topography and vegetation.

DESCRIPTION: Decide how best to describe the site. If there is evidence of past or present beaver activity, circle one of these choices in addition to your choice.

LENGTH, WIDTH: Record the maximum length and width of lakes and ponds. For streams, recond the length and average width of the reach searched.

MAXIMUM DEPTH: Most times, you will not have access to a boat, so estimate depth (deep lakes are usually not important to amphibians).

STREAM ORDER: This is an index of stream size, and you will need a topographic map to determine it. Firstorder streams have no tribuaries, second-order streams are formed by the confluence of two $1^{\alpha}$-order streams, thind-order streams are formed by the confluence of two $2^{\text {sd }}$-order streams, and so on.

PRIMARY SUBSTRATE: Circle the type that covers the majority of the bottom of the site.

EMERGENT VEGETATION: Circle the percentage of the margin of the site with emergent vegetation present, and list the dominant species. If you are botanicallydisadvantaged, list the categories of the dominant species (e.g., cattail, sedges, etc.).

NORTH SHORELINE CHARACTERS: Describe the north shore of a lake or pond in terms of shallow water and emergent vegetation. This is important in evaluating quality of breeding habitat in some mountain locations

FOREST CHARACTERS: List the closest distance between the water and the surrounding forest, and list the most common tree species. Leave these fields blank if there is no forest. Describe other surrounding habitat types in the notes section on the back of the form. 
AMPHIBIAN SURVEY DATA SHEET - US ASH \& MLOLFE SERMCE, 4512 MEMURRY AVE, TT. COLUNS, CO $80626-3400$

(circle cheies for aheded veriablea; oupply valu for othent)

(vor. 2 $7 / 92)$

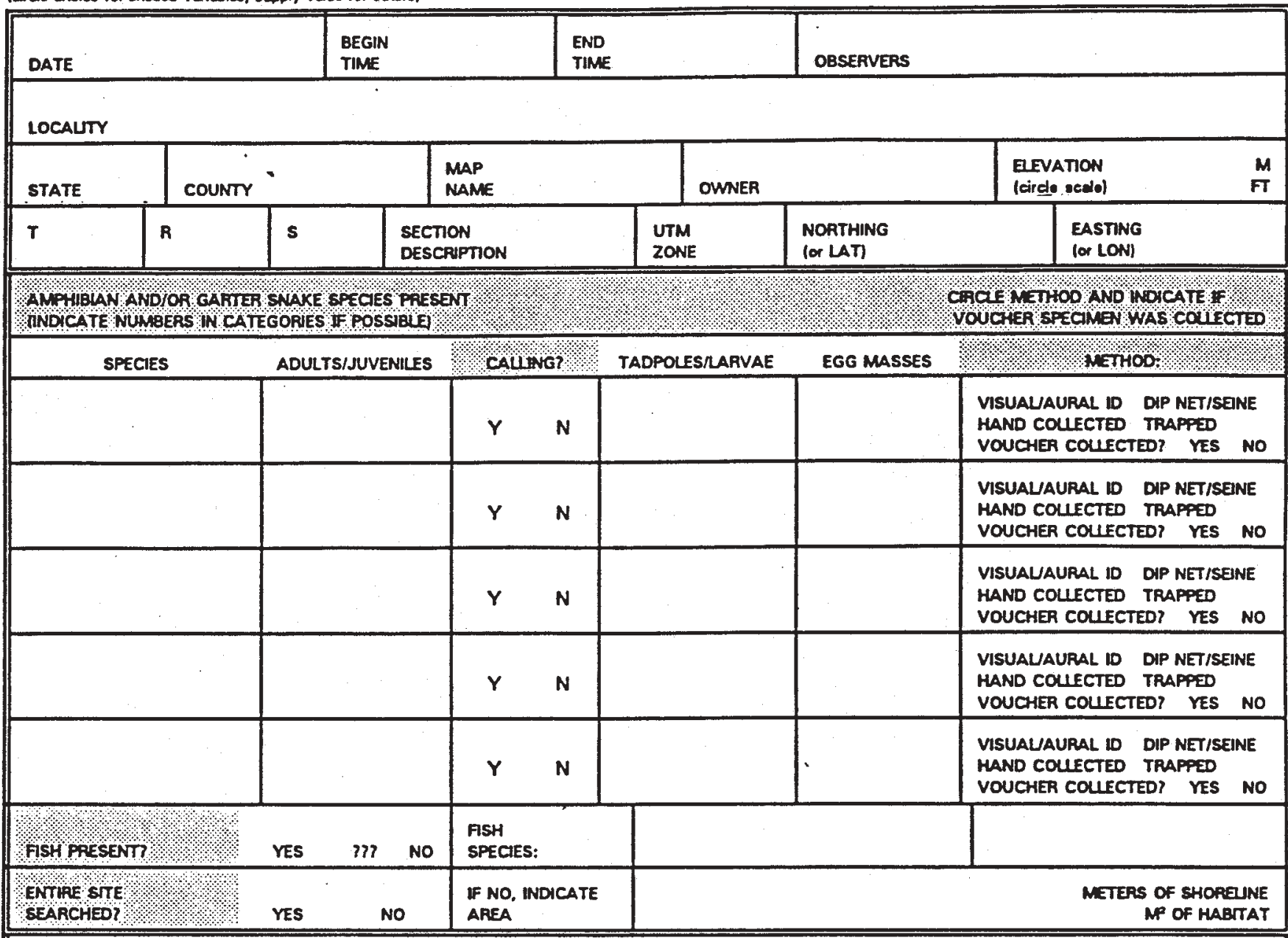

PHYSICAL ANO CHEMHCAL ENVIRONMENT ICHEMSTRY VARIABEES OPTIONAL USE EXTRA SPACES FOR ADOITONAI MES SUREMENTSI

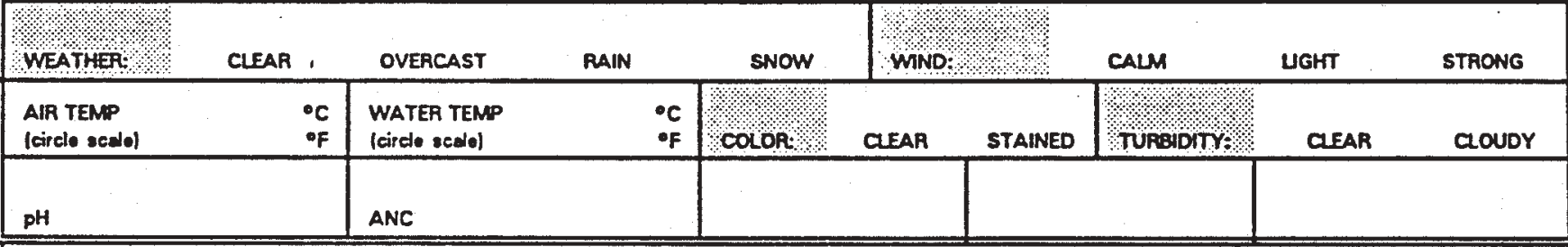

STTE DESCPAPTIONS ISKETCH STTE AND PUT ADOTIONAL COMWENTS ON AACK OF SHET)

ONT THIS SECTION IF DATA HAVE BEEN COUECTED ON A PREVMOUS VISIT

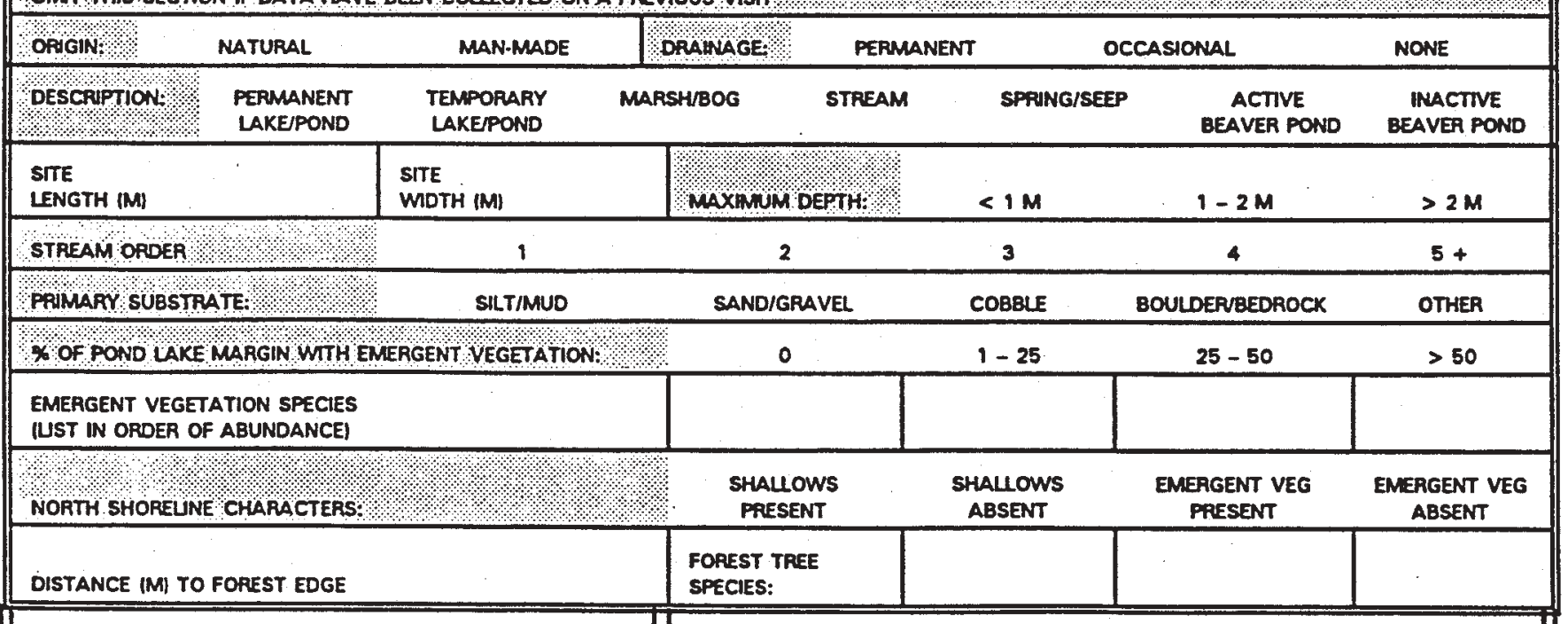

Gap/USFS Habitat 


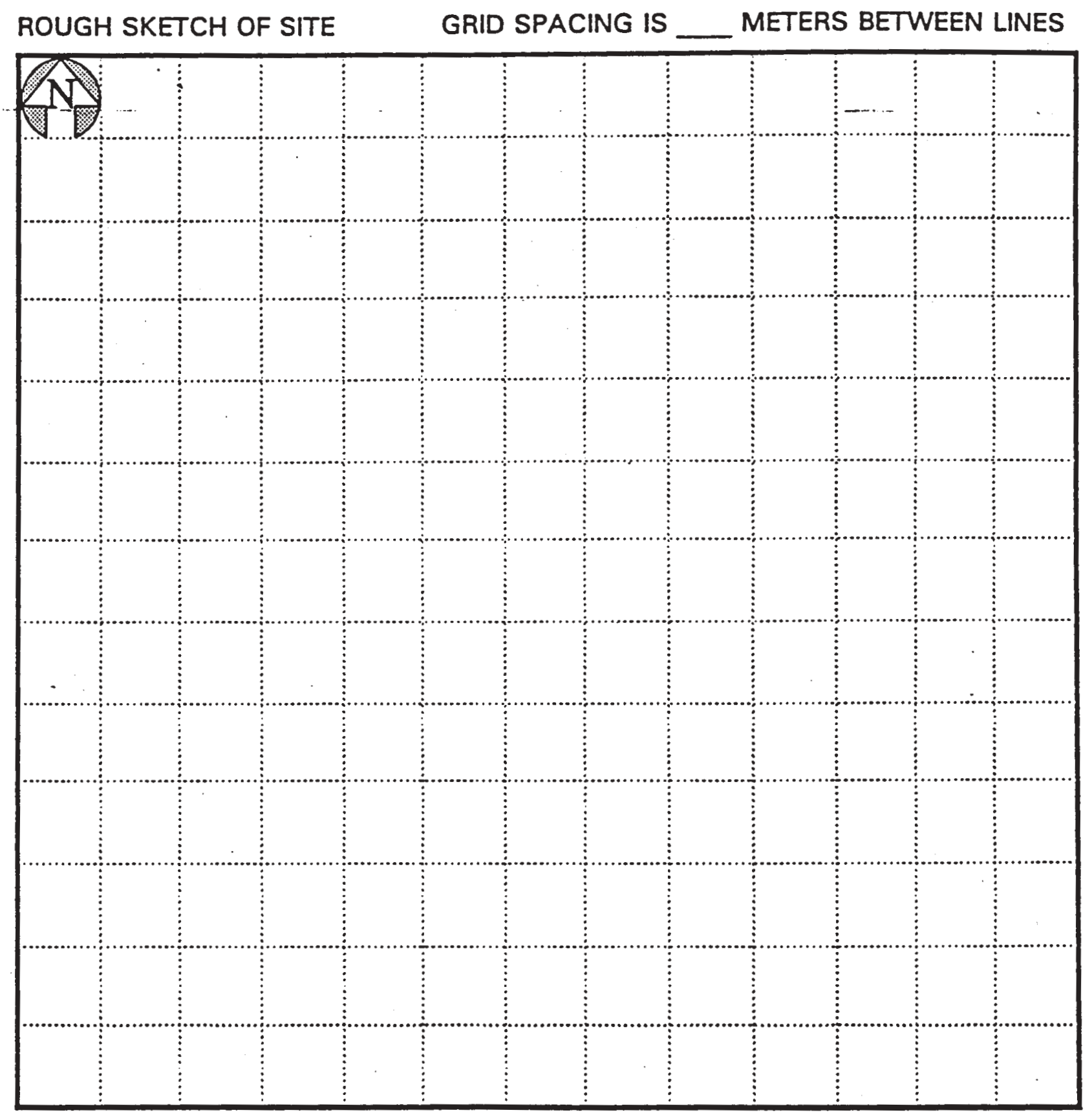

ADDITIONAL NOTES: 
Miscellaneous Observation Form Montana Natural Heritage Program $1515 \mathrm{E}$ 6th Ave

PO Box 201800

Helena, MT 59620-1800

Observer

Address

Phone No.

INSTRUCTIONS" Please use this sheet to submit sight, call, or specimen records of any Montana amphibian or reptile species. Use a separate line for each species and site. On the back of the sheet include any additional comments or supporting information. Please provide as specific location information as possible, particularly for the following species of special concern: Coeur d'Alene Salamander, Idaho Giant Salamander, Tailed Frog, Canadian Toad, Wood Frog, Snapping Turtle, Spiny Softshell, Short-horned Lizard,

Sagebrush Lizard, Western Hognose Snake, and Smooth Green Snake. Documentation is required for Idaho Giant Salamander and Wood Frog (photo, through description, verification by experienced observer, etc.). An identification guide is available in the May/June 1995 issue of Montana Outdoors (reprints available at the MT Nat. Heritage Prog).

\begin{tabular}{|c|c|c|c|c|c|c|c|}
\hline Species & Location & County & $\begin{array}{l}\text { Township Range Section } \\
\text { or UTM }\end{array}$ & $\begin{array}{l}\text { Date } \\
\text { Mo/Day/Yr }\end{array}$ & Time & $\begin{array}{l}\# \\
\text { Adults } \\
\end{array}$ & $\begin{array}{l}\# \\
\text { Larvae } \\
\end{array}$ \\
\hline Example: Leopard Frog & McNab Pond & Carter & T01N R59E Sect 19 NE & $5 / 20 / 94$ & $8: 30 \mathrm{a}$ & 5 & 200 \\
\hline Example: Milk Snake & $3.4 \mathrm{mi} \mathrm{W}, 1.2 \mathrm{mi} \mathrm{N}$ of Harlowton & Wheatland & $5145200 \mathrm{~N}, 584700 \mathrm{E}$ & $8 / 15 / 94$ & $11: 15 p$ & 1 & \\
\hline 1. & & & & & & & \\
\hline 2. & & & & & & & \\
\hline 3. & & & & & & & \\
\hline 4. & & & & & & & \\
\hline 5. & & & & & & & \\
\hline 6. & & & & & & & \\
\hline 7. & & & & & & & \\
\hline 8. & & & & & & & \\
\hline 9. & & & & & & & \\
\hline 10. & & & & & & & \\
\hline 11. & & & & & & & \\
\hline
\end{tabular}


Comments: Include mcthod of observation, measurements, documentation for species of special concern, disposition of specimens, weather, etc. Numbers correspond to those on the other side of this shcet. Use additional space or sheets if necessary.

Example: Sunny warm day, about $75^{\circ}$. Adults ( 3 seen; 2 hcard calling only) at margin of ponds in cattails. Very small tadpoles seen; 1 egg mass still present.

Example: Found dead in the road in sagebrush flat near rimrocks; 24" long; Colored with bands of yellow / black/ red / black / yellow...; deposited in MSU Museum

1 .

2.

3.

4.

6.

7.

10.

11. 


\section{APPENDIX 2.}

\section{SITES SURVEYED DURING 1993-94}

\section{AMPHIBIAN AND REPTILE SURVEYS}




\begin{tabular}{|c|c|c|c|c|c|}
\hline Site & Location & Elevation & Date & Start & Time \\
\hline
\end{tabular}

\section{LEWIS AND CLARK NATIONAL FOREST Rocky Mountain District}

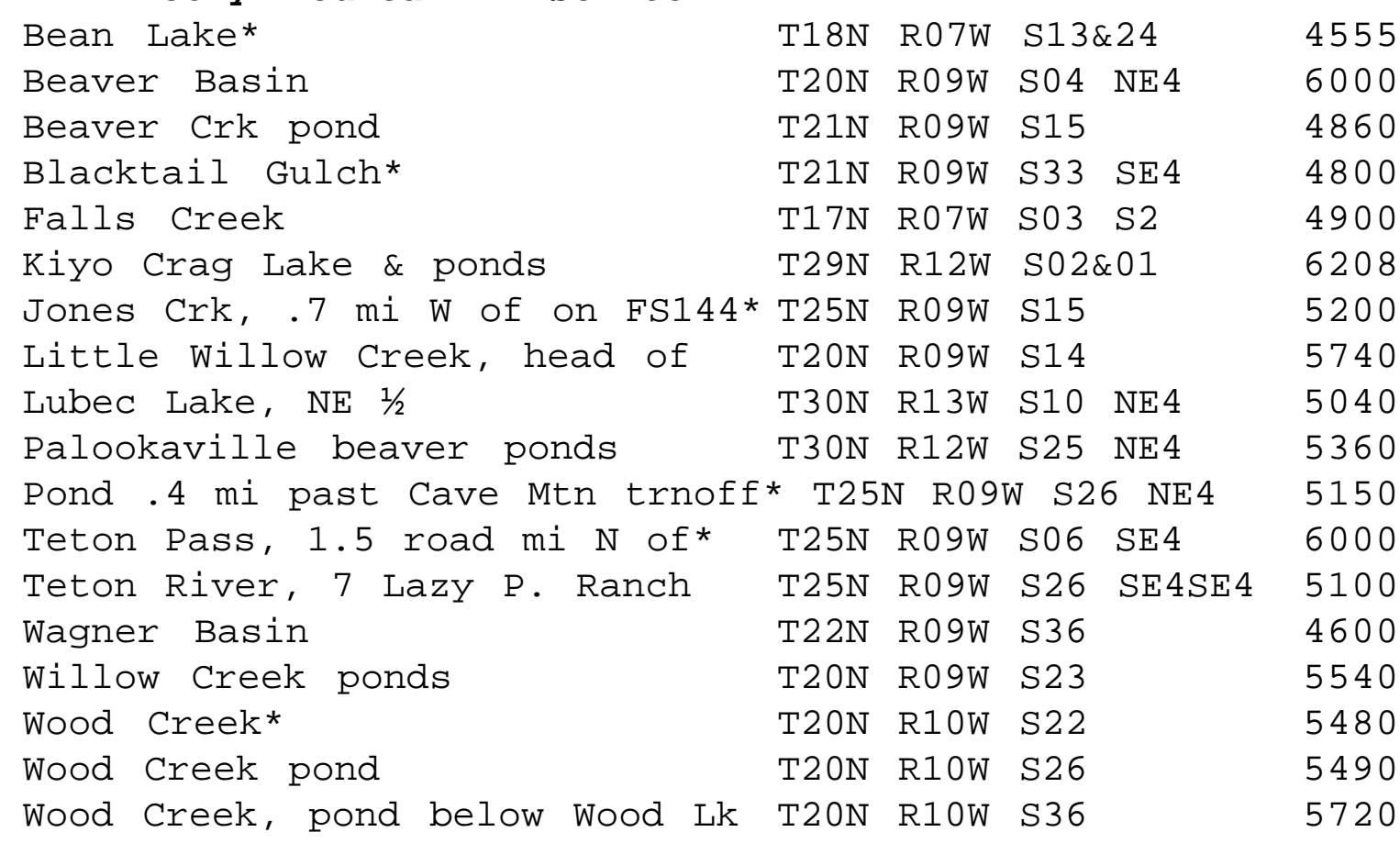

$\begin{array}{llll}04 & \text { Jul } & 94 & 1615 \\ 27 & \text { May } 94 & 1420 \\ 27 & \text { May } 94 & 1510 \\ 05 & \text { Jul } 94 & 1550 \\ 05 & \text { Jul } 94 & 1030 \\ 06 & \text { Jul } 94 & 1035 \\ 26 & \text { May } 94 & 1630 \\ 27 & \text { may } 94 & 1350 \\ 25 & \text { May } 94 & 1800 \\ 06 & \text { Jul } 94 & 1455 \\ 26 & \text { May } 94 & 1825 \\ 26 & \text { May } 94 & 1730 \\ 26 & \text { May } 94 & 1515 \\ 05 & \text { Jul } 94 & 1330 \\ 27 & \text { May 94 } & 1245 \\ 27 & \text { May } 94 & 0945 \\ 27 & \text { May } 94 & 1025 \\ 27 & \text { May 94 } & 1130\end{array}$

* Sites with no herps found during survey 


\section{Site \\ JEFEERSON DIVISION \\ Big Snowy Mountains \\ Crystal Lake}

T12N R17E S13

6000

6100

T06N R10E S10

T06N R10E S26\&35

6490

Forest Lake

\section{Castle Mountains}

Blackhawk Cabins meadows* Checkerboard Crk, E Fork hdwtr*

Checkerboard Creek, W Fork

Lennep, pond .8 $\mathrm{mi} \mathrm{N}$

Thorsen's Pond*

\section{Highwood Mountains}

Briggs Creek seep*

Highwood Crk, nr Cow Camp

Highwood Creek, middle*

T09N R08E S36

T09N R08E S25\&36

T09N R08E S24

T08N R09E S25

T09N R09E S20 NW4

6850

6700

6200

5350

6560

T20N R09E S28 NE4NW4 4520

T20N R09E S29 NW4 4440

T20N R09E S33 center 4680

Highwood Creek, beaver complex* T19N R09E S09 NE4 5020

Highwood Creek, hdwtrs seeps* T19N R09E S15 NW4 5320
Date

Start Time

07 Jul 94

1400

08 Jul 94

07 Jul 94

0950

1835

08 Jul 94

08 Jul 94

08 Jul 94

08 Jul 94

08 Jul 94

1345

1410

1530

1205

1310

$\begin{array}{lll}28 & \text { May } & 94 \\ 28 & \text { May } & 94 \\ 28 & \text { May } & 94 \\ 28 & \text { May } & 94 \\ 28 & \text { May } & 94\end{array}$

1300

1330

1405

1430

1525

* Sites with no herps found during survey 
Appendix 2. (cont.) Sites surveyed during 1994 amphibian and reptile surveys.

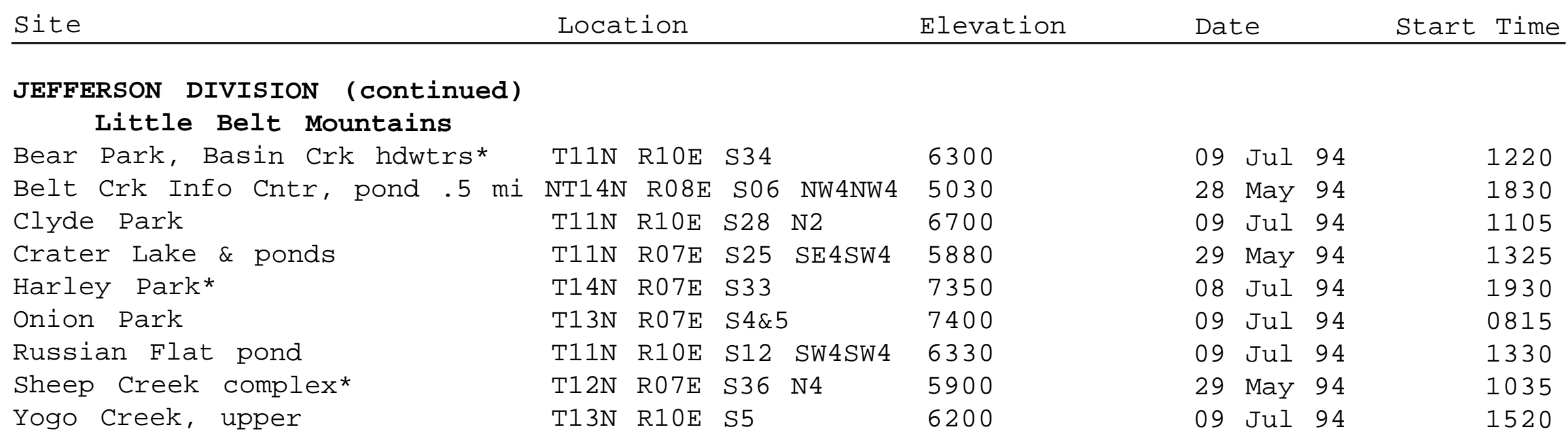




\section{APPENDIX 3.}

\section{AMPHIBIANS AND REPTILES}

\section{OBSERVED DURING SURVEYS OF THE}

\section{LEWIS AND CLARK NATIONAL FOREST}

IN 1994 
Appendix 3. Amphibians and reptiles observed during surveys of the Lewis and Clark National Forest in 1993-94

\begin{tabular}{lll}
\hline Site & & \\
& Person & Total number of adults/juv of each species observed \\
Hrs:min & AMMA AMTI ASTR BUBO PSTR RAPR THSI THEL \\
\hline
\end{tabular}

\section{Rocky Mountain District}

Beaver Basin

Beaver Crk pond

Falls Creek

$0: 20$

$0: 50$

$1: 30$

Kiyo Crag Lake/pond 3:20

Little Willow Creek 0:30

Lubec Lake, $\mathrm{NE} 1 / 2 \quad 1: 15$

Palookaville ponds 1:20

Teton River, 7 Lazy P1:10

Wagner Basin 3:10

Willow Creek ponds 1:20

Wood Ck, belw Wood Lk0:40
Wood Creek pond 1:10

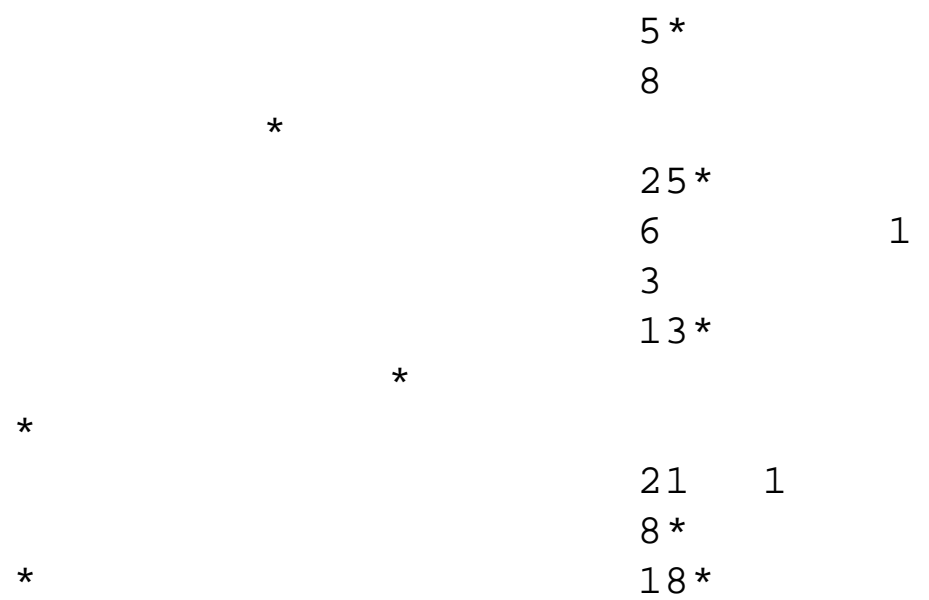

${ }^{1} \mathrm{AMMA}=$ Ambystoma macrodactylum; AMTI=Ambystoma tigrinum; boreas; $\mathrm{PSRE}=$ Pseudacris regilla; RAPR=Rana pretiosa; THSI=Thamnophis sirtalis; THEL=Thamnophis elegans.
ASTR=Ascaphus truei; $B U B O=B u f o$

*denotes site with breeding, i.e. tadpoles, larvae, or eggs present 
Appendix 3. (cont.) Amphibians and reptiles observed during surveys of the Lewis and Clark National Forest in 1993-94

$\begin{array}{lll}\text { Site } & \text { Person } & \text { Total number of adults/juv of each species observed } \\ & \text { Hrs:min AMMA AMTI ASTR BUBO PSTR RAPR THSI THEL }\end{array}$

\section{JEFFERSON DIVISION \\ Big Snowy Mountains}

Crystal Lake $\quad 1: 35$

\section{Crazy Mountains}

Forest Lake

$1: 35$

\section{Castle Mountains}

Checkerboard Ck, W Fk0:20

Lennep, pond .8 mi $\mathrm{N} 0: 11$

\section{Little Belt Mountains}

$\begin{array}{ll}\text { Belt Crk Info Cntr } & 0: 20 \\ \text { Clyde Park } & 0: 52 \\ \text { Crater Lake \& ponds } & 1: 00 \\ \text { Onion Park } & 0: 57 \\ \text { Russian Flat pond } & 0: 15 \\ \text { Yogo Creek, upper } & 1: 00\end{array}$

${ }^{1} \mathrm{AMMA}=$ Ambystoma macrodactylum; AMTI=Ambystoma tigrinum; ASTR=Ascaphus truei; BUBO=Bufo boreas; $\mathrm{PSRE}=$ Pseudacris regilla; RAPR=Rana pretiosa; THSI=Thamnophis sirtalis; THEL=Thamnophis elegans .
2

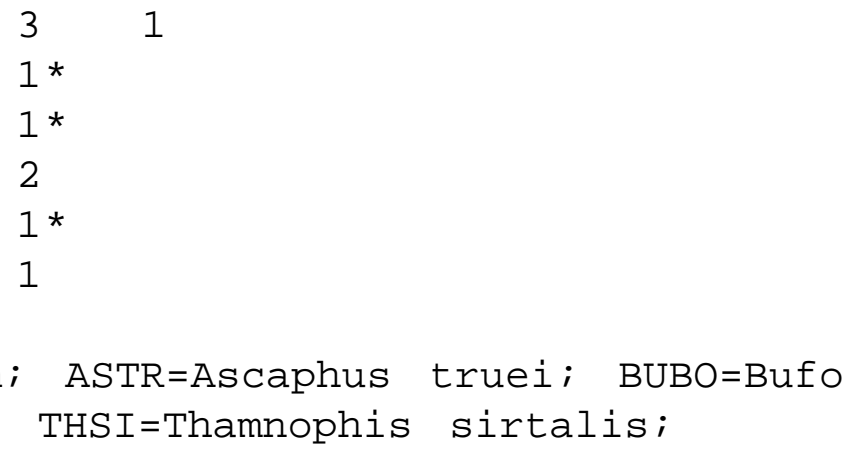

2

1 *

(1)

*denotes site with breeding, i.e. tadpoles, larvae, or eggs present 


\section{APPENDIX 4.}

\section{AMPHIBIANS AND REPTILES}

REPORTED FROM IN AND AROUND THE

LEWIS AND CLARK NATIONAL FOREST 


\title{
LONG TOED SALAMANDER
}

\author{
Granite .5 to $5 \mathrm{mil} / / 0$ No Observation \\ Kitchen Creek, near Missoula \\ Jefferson .5 to 5 mil 4/28/1962 No Museum Specimen \\ $2 \mathrm{mi}$. S. of East Helena on branch McClellen Creek \\ Jefferson .5 to 5 mil 4/28/1962 No Museum Specimen \\ S. of East Helena on Al Palmer Ranch \\ Jefferson .5 to 5 mil 4/28/1962 Yes Museum Specimen \\ 2 mi. s. of East Helena on branch McClellen Creek \\ Jefferson .5 to 5 mil 8/25/1959 No Museum Specimen \\ Horse trough off McClellen Creek \\ Jefferson .5 to 5 mil 7//1972 No Museum Specimen \\ Near Clancy \\ Lewis \& Clark <.5 mile. 5/27/1994 Yes Observation \\ Wood Creek, just below Wood Lake, $5700 \mathrm{ft}$. \\ Lewis \& Clark <.5 mile. 7/ 5/1994 Yes Museum Specimen \\ Wagner Basin, $4600 \mathrm{ft}$. \\ Lewis \& Clark .5 to 5 mil 7/13/1983 No Museum Specimen \\ Upper Grizzly Gulch \\ Missoula .5 to 5 mil 4/24/1950 No Observation \\ Overflow of Union Creek, near McNamara, ca. $3500 \mathrm{ft}$. \\ Missoula $<.5$ mile. 7/ 1/1993 No Observation \\ $\mathrm{S}$ of NW1/4 of section 29, pond $\mathrm{E}$ of Boles PT. \\ Missoula $<.5$ mile. 7/ 1/1993 No Observation \\ NW of NE of section 32 , lily pad pond.

\section{TIGER SALAMANDER} \\ Cascade 5 to $10 \mathrm{mil} 11 / / 1992$ No Observation \\ Malmstrom AFB near Great Falls \\ Cascade $\quad .5$ to 5 mil $/ 18 / 1942$ No Museum Specimen \\ 5 miles S. of Great Falls \\ Chouteau >10 miles. / / 0 No Museum Specimen \\ Fort Benton \\ Chouteau 5 to $10 \mathrm{mil} \mathrm{9//1967} \mathrm{No} \mathrm{Observation}$ \\ Teton River near Fort Benton
}


Montana Animal Atlas (Herpetile) Species Report

County Precision Date Breed Data Type

\section{TIGER SALAMANDER (continued)}

Glacier > 10 miles. / / 0 No Museum Specimen Blackfoot Indian Reservation, 16 miles SW of Cut Bank

Glacier .5 to 5 mil / / 0 No Observation $4 \mathrm{mi}$ NE of Marias Pass summit

Meagher $\quad<.5$ mile. 7/8/1994 Yes Observation Pond $0.8 \mathrm{mi}$. N. of Lennep

Teton $<.5$ mile. 6/22/1993 No Observation S.E. Pine Butte

Unknown $\quad .5$ to 5 mil $/ 18 / 1917$ No Museum Specimen Volta Dam, 13.5 miles below Great Falls

Unknown >10 miles. 9/10/1952 No Museum Specimen Lothair

Wheatland .5 to 5 mil 7//1904 No Museum Specimen Winnecook Ranch: Stock reservoir

Wheatland <.5 mile. / /1994 No Observation Chief Joseph Park Pond, Harlowton

\section{TAILED FROG}

Flathead $\quad .5$ to 5 mil 7/11/1934 No Museum Specimen Glacier National Park 3.5 miles above mouth of Muir creek

Flathead $>10$ miles. 7/24/1934 No Museum Specimen Glacier National Park, Coal Creek tributaries

Flathead .5 to 5 mil 6/28/1934 No Museum Specimen Glacier National Park, 8 mi above mouth of Ole Creek

Flathead $\quad .5$ to 5 mil 7/6/1934 No Museum Specimen Glacier National Park, 6 mi above mouth of Park Creek

Flathead 5 to $10 \mathrm{mil} \mathrm{/} \mathrm{/} 0$ No Observation Coal Creek

Flathead 5 to $10 \mathrm{mil} / / 0$ No Observation Ole Creek

Flathead 5 to 10 mil / / 0 No Observation Park Creek 
Montana Animal Atlas (Herpetile) Species Report

County Precision Date Breed Data Type

TAILED FROG (continued)

Flathead .5 to 5 mil / /1969 No Observation

Soldier and Clark Creeks

Flathead .5 to 5 mil / /1969 No Observation Bear and Skyland Creeks

Flathead .5 to 5 mil / / 0 No Museum Specimen Midvale Creek, near Glacier National Park

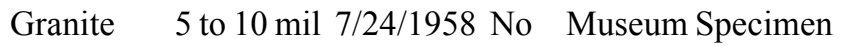

Ranch Creek, ca. 11 mi. S. of I 90 on Rock Creek Rd.

Granite $\quad .5$ to 5 mil 7/24/1958 No Museum Specimen

Ranch Creek (tributary of Rock Creek)

Lewis \& Clark 5 to 10 mil / / 0 No Observation

Tributary of Copper Creek, tributary of the Blackfoot River

Lewis \& Clark <.5 mile. 7/ 5/1994 Yes Museum Specimen Falls Creek, crossing down to falls.

Missoula .5 to 5 mil 5/4/1947 No Observation Spring on Gold Creek, near Gold Creek Ranger Station

Missoula 5 to 10 mil 7/22/1950 No Museum Specimen

Placid Creek, ca. 4 mi. SW of Seeley Lake

Missoula .5 to $5 \mathrm{mil} / / 1969$ No Observation Owl Creek

Pondera $<.5$ mile. 10/7/1994 Yes Observation E Fork Woods Creek; also sec. 16, Whiterock Creek

Powell 5 to $10 \mathrm{mil} / / 0$ No Observation Morrell Creek, tributary of Clearwater River

Teton $<.5$ mile. 7/8/1994 Yes Observation

On Mt. Wright hiking trail at small stream that trail crosses.

\section{WESTERN TOAD}

Broadwater >10 miles. / /1966 Yes Observation Near Canyon Ferry Reservoir, small spring in open ponderosa pine.

Carbon $\quad .5$ to 5 mil / /1966 No Observation Kings Hill, $7000 \mathrm{ft}$. 
Natural Heritage Program

03/04/1995

Montana Animal Atlas (Herpetile) Species Report

County Precision Date Breed Data Type

\section{WESTERN TOAD (continued)}

Cascade $\quad .5$ to $5 \mathrm{mil} / \mathrm{/} 0$ No Museum Specimen

Little Belt Mountains, 1.2 miles N. (Hwy 89) of Kings Hill Pass, $7200 \mathrm{ft}$.

Chouteau .5 to 5 mil 6/24/1962 Yes Museum Specimen

Highwood Creek near Arrow Creek Divide

Chouteau .5 to 5 mil 6/24/1962 No Museum Specimen

Highwood Creek near Arrow Creek Divide

Chouteau .5 to 5 mil 6/24/1962 Yes Museum Specimen

Upper Highwood Creek near pass to Arrow Creek

Chouteau .5 to 5 mil 6/24/1962 Yes Museum Specimen Upper Highwood Creek near pass to Arrow Creek

Flathead >10 miles. 7/6/1934 No Museum Specimen Park Creek, Glacier National Park.

Flathead .5 to 5 mil 7/23/1949 No Observation South Fork River and Addition Creek

Granite $\quad .5$ to 5 mil 7/11/1977 Yes Museum Specimen $1 / 4 \mathrm{mi} \mathrm{W}$ of Bearmouth, rest area off I 90.

Lewis \& Clark .5 to 5 mil 7/12/1958 No Museum Specimen Bear Lake, 7000 feet

Meagher >10 miles. 8/4/1899 No Museum Specimen Deep Creek Canyon, Big Belt Mountains

Meagher 5 to $10 \mathrm{mil} 9 / 5 / 1918$ No Museum Specimen $6 \mathrm{mi} \mathrm{SW}$ of Lennep.

Meagher > 10 miles. 8/23/1919 No Museum Specimen Fort Logan, Camas Creek (4 mi S).

Meagher $\quad .5$ to 5 mil 8/20/1951 No Museum Specimen Sheep Creek near Jumping Creek Campgrounds

Meagher .5 to 5 mil 8/24/1951 Yes Museum Specimen Adams Ranch, Sheep Creek

Meagher .5 to 5 mil 8/6/1958 No Museum Specimen Lake Creek 
Natural Heritage Program

03/04/1995

Montana Animal Atlas (Herpetile) Species Report

County Precision Date Breed Data Type

\section{WESTERN TOAD (continued)}

Missoula .5 to 5 mil 5/2/1948 No Observation

Morrel Creek near Seeley Lake; Archibald Creek near Seeley Lake, $4000 \mathrm{ft}$.

Missoula .5 to $5 \mathrm{mil} / / 1966$ No Observation

Rainy Lake

Missoula $<.5$ mile. 7/1/1993 No Observation

S of NW1/4 of section 29, Pond E of Boles Point.

Phillips .5 to 5 mil 8/10/1972 No Museum Specimen

Slippery Ann Station

Pondera $<.5$ mile. 7/13/1994 No Observation

Damp area along E Fork Woods Creek.

Teton $<.5$ mile. 5/26/1994 Yes Observation

7 Lazy P Ranch, Lewis and Clark NF, $5100 \mathrm{ft}$.

Teton $<.5$ mile. 6/21/1993 Yes Observation

NW of NW section 13, Pine Butte Swamp Preserve.

Wheatland > 10 miles. / /1966 No Observation

Grassy spring in the short grass prarie W. of Harlowton

\section{GREAT PLAINS TOAD}

Toole $\quad .5$ to 5 mil 7/20/1950 Yes Observation cattle pond on the prairie apprx. $1 \mathrm{mi} \mathrm{S}$ of camp (10 mi S of Galata)

\section{WOODHOUSEíS TOAD}

Fergus $\quad .5$ to 5 mil 7/24/1919 No Museum Specimen On Missouri River 5 miles north of Wilder

Fergus $\quad .5$ to 5 mil 8/9/1991 No Museum Specimen Missouri River at Fred Robinson Bridge.

Mussellshell .5 to 5 mil 8/7/1918 No Museum Specimen 1 mile west of Kline

\section{WESTERN CHORUS FROG}

Cascade $\quad<.5$ mile. 5/28/1994 No Call Heard Only

On Hwy 89 go $5 \mathrm{mi}$. W. of Hwy 200 junction to pond on N. side of road 
Natural Heritage Program

03/04/1995

Montana Animal Atlas (Herpetile) Species Report

County Precision Date Breed Data Type

WESTERN CHORUS FROG (continued)

Cascade 5 to 10 mil 6/7/1993 No Observation

Chestnut Valley Sand hills

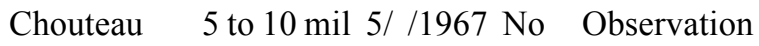
Near Fort Benton

Chouteau .5 to 5 mil 7/22/1962 Yes Museum Specimen Swan Ranch E. of Highwood

Fergus $\quad .5$ to 5 mil 7/26/1991 No Museum Specimen

5 mi. E. of Roy

Glacier <.5 mile. 5/25/1994 No Call Heard Only

Both ponds at intersection, T30N R11W S16

Judith Basin < <.5 mile. 5/27/1994 No Call Heard Only

T18N R10E S20

Judith Basin <.5 mile. / /1994 No Observation

Also T19N R09E Sec. 22, offFS RD 122.

Judith Basin < $<$ mile. 5/28/1994 No Museum Specimen 5 mi. N., 3 mi. W. of Geyser, $4370 \mathrm{ft}$.

Lewis \& Clark < 5 mile. 5/27/1994 No Call Heard Only Anderson Lake

Liberty $<.5$ mile. 7/7/1994 Yes Museum Specimen Moffat Bridge on Marias River, ca. 6 mi. ESE of Tiber Dam

Petroleum 5 to 10 mil 8//1968 No Museum Specimen Near War Horse Lake

Pondera $<.5$ mile. 5/26/1994 No Museum Specimen T28N R8W S5

Pondera $<.5$ mile. 7/13/1994 No Observation Spring seep area T29N R12W S9.

Teton $<.5$ mile. 6/21/1993 No Observation NE1/4 of NE1/4 S34, near the Teton River, Pine Butte Swamp Preserve.

Teton $<.5$ mile. 6/21/1993 No Observation NW of NW sec 13 Pine Butte Swamp Preserve. 
Natural Heritage Program

03/04/1995

Montana Animal Atlas (Herpetile) Species Report

County Precision Date Breed Data Type

WESTERN CHORUS FROG (continued)

Teton $<.5$ mile. 6/22/1993 No Observation

SE of SE of S2, Pine Butte Swamp Preserve.

Teton $<.5$ mile. 6/22/1993 No Observation

Bellview Rd Pond

Teton $<.5$ mile. 6/22/1993 No Observation

NE1/4 of Sect 17, Pine Butte Swamp Preserve.

Teton $<.5$ mile. 6/22/1993 No Observation

SE Pine Butte

Toole $>10$ miles. 7/ /1950 No Observation

in the area near camp (10 $\mathrm{mi} \mathrm{S}$ of Galata)

Wheatland >10 miles. 8/29/1918 No Museum Specimen 5 miles SW of Oka

\section{PLAINS SPADEFOOT}

Cascade $\quad .5$ to 5 mil //1934 No Museum Specimen 4.5 miles W. of Great Falls

Cascade $\quad .5$ to 5 mil 8/31/1948 No Museum Specimen

3 mi. S. of Cascade, Missouri River

Cascade $\quad .5$ to 5 mil 9/ /1962 No Museum Specimen NE of Great Falls

Cascade $<.5$ miles / /1992 Yes Observation Great Falls

Toole $\quad .5$ to $5 \mathrm{mil} 7 / 21 / 1950$ No Observation dry flood plain at camp (10 mi S of Galata)

\section{NORTHERN LEOPARD FROG}

Broadwater <.5 mile. 5/10/1993 No Observation Deepdale FAS. Directly E. across channel from Deepdale BE nest

Cascade $<.5$ miles 6/ /1994 No Observation cutoff slough along Belt Creek, T18N R6E Sec 12

Lweis and Clark $<.5$ miles / /1993 No Observation small riparian ponds along Dearborn River, T18N R7W Sec. 25 


\section{NORTHERN LEOPARD FROG (continued)}

Chouteau .5 to 5 mil 6/24/1962 No Museum Specimen Upper Highland Creek near Arrow Creek Divide.

Chouteau .5 to 5 mil 6/24/1962 No Museum Specimen Upper extreme of Highwood Creek, near mouth of Beaver Creek

Chouteau .5 to 5 mil 8/31/1948 No Museum Specimen 3 mi. S. of Cascade, Missouri River

Fergus $\quad .5$ to 5 mil 8/20/1918 No Museum Specimen 8 miles W. of Lewistown, on Beaver Creek

Fergus $\quad .5$ to 5 mil 8/19/1918 No Museum Specimen 7 miles NE of Lewistown, Judith Mountains

Fergus $\quad .5$ to 5 mil 7/28/1919 No Museum Specimen 7 miles NE of Hilger

Fergus $\quad .5$ to 5 mil 8/4/1919 No Museum Specimen 5 miles NW of Hilger, Moccassin Mountains

Fergus $\quad<.5$ mile. $8 / 28 / 1994$ No Observation T13N R22E S23

Fergus $\quad 5$ to 10 mil 8/13/1948 No Museum Specimen Beaver Creek, S. of Lewistown

Lewis \& Clark 5 to 10 mil 7/18/1958 No Museum Specimen Sun River, 5500 feet

Liberty 5 to 10 mil 6/13/1950 No Observation 6 miles east of reservoir area at Turner Memorial Park

Meagher $\quad .5$ to 5 mil 8/30/1918 No Museum Specimen Martinsdale, S. fork of Missellshell River

Meagher .5 to 5 mil 10/21/1950 No Museum Specimen S. Fork Mussellshell near Lennep

Powell 5 to 10 mil 7/3/1973 No Museum Specimen North Fork of Blackfoot River

Teton $<.5$ mile. 7/21/1993 No Observation NE of NE of sect 7, Pine Butte Swamp Preserve.

Teton $\quad .5$ to 5 mil 8/27/1949 No Museum Specimen 5 mi. E. of Choteau. 
Montana Animal Atlas (Herpetile) Species Report

County Precision Date Breed Data Type

\section{NORTHERN LEOPARD FROG (continued)}

Wheatland .5 to $5 \mathrm{mil} / 18 / 1942$ No Museum Specimen Musselshell River at Shawmut

Wheatland .5 to 5 mil 8/28/1918 No Museum Specimen 5 miles SW of Oka

Wheatland .5 to 5 mil 8/28/1918 No Museum Specimen 3 miles N. of Judith Gap

\section{SPOTTED FROG}

Cascade $\quad .5$ to $5 \mathrm{mil} / \mathrm{/} 0$ No Museum Specimen Little Belt Mountains, 1.2 miles N. of Kings Hill Pass

Cascade $\quad .5$ to 5 mil 8/8/1944 No Museum Specimen 12 miles S. of Neihart

Cascade $\quad .5$ to 5 mil 6/27/1973 No Museum Specimen North of Kings Hill Campground, Hwy. 89, Little Belt Mountains

Cascade $<.5$ mile. 5/28/1994 No Museum Specimen Pond $0.5 \mathrm{mi} \mathrm{N}$. of Belt Creek Info Center on E. side of Hwy. 89

Flathead .5 to 5 mil 7/25/1934 No Museum Specimen Galcier National Park, Marthaís Basin Lake

Glacier $<.5$ mile. 5/25/1994 No Observation NE 1/4 of Lubec Lake, $5040 \mathrm{ft}$.

Glacier <.5 mile. 7/6/1994 Yes Observation Palookaville Beaver Ponds

Granite .5 to 5 mil 7/11/1977 No Museum Specimen 0.25 mile W. of Bear Mouth, at rest area off Hwy. 90 .

Jefferson .5 to 5 mil 7/8/1944 No Museum Specimen 5 miles W. of Bernice

Judith Basin < $<5$ mile. 5/20/1994 No Observation Along tributary to Dry Pole Gulch.

Judith Basin <.5 mile. 7/9/1994 Yes Observation Clyde Park, Little Belt Mountains, $6700 \mathrm{ft}$.

Judith Basin <.5 mile. 7/9/1994 No Observation Upper Yogo Creek, Little Belt Mountains, $6200 \mathrm{ft}$. 
Montana Animal Atlas (Herpetile) Species Report

County Precision Date Breed Data Type

\section{SPOTTED FROG (continued)}

Judith Basin < $<.5$ mile. 7/9/1994 Yes Observation Pond in Russian Flat, Little Belt Mountains

Judith Basin .5 to 5 mil 7/12/1991 Yes Museum Specimen Clyde Park Pond, Litle Belt Mountains

Lewis \& Clark .5 to 5 mil / / 0 No Observation 2.3 miles W. of Flasher Pass tributary of Blackfoot River

Lewis \& Clark <.5 mile. 5/27/1994 Yes Museum Specimen Wood Creek, just below Wood Lake

Lewis \& Clark <.5 mile. 5/27/1994 Yes Observation Willow Creek Ponds, $5540 \mathrm{ft}$, also Sec. 14

Lewis \& Clark $<.5$ mile. 5/27/1994 No Observation Pond above Beaver Creek, S. of Green Timber Basin.

Lewis \& Clark <.5 mile. 9/3/1994 No Observation Prickley Pear Creek just W. of Stansfield Lake.

Lewis \& Clark <.5 mile. 5/27/1994 No Observation Head of Little Willow Creek.

Lewis \& Clark <.5 mile. 5/27/1994 Yes Observation Beaver Basin (road sign)

Lewis \& Clark <.5 mile. 5/27/1994 Yes Museum Specimen Wood Creek

Lewis \& Clark $<.5$ mile. 7/27/1975 No Observation

Pond, ca. $400 \mathrm{~m}$ from the main stack of East Helena Smelter.

Lewis \& Clark <.5 mile. 7/27/1975 No Observation

Ca. $1.6 \mathrm{~km}$ SSE from the East Helena Smelter in springs

Lewis \& Clark <.5 mile. 7/27/1975 No Observation McClellan Creek Quarry Lake

Lewis \& Clark < 5 mile. 5/22/1994 No Museum Specimen 7 Up Pete Proposed Gold Mine area on HWY 200, ca. 10 mi. E. of Lincoln.

Meagher $\quad .5$ to 5 mil 9/3/1918 No Museum Specimen Martinsdale, S. Fork of Mussellshell River

Meagher $\quad .5$ to 5 mil 6/ 1/1978 No Museum Specimen Dry Fork of Musselshell River 


\section{SPOTTED FROG (continued)}

Meagher <.5 mile. 5/29/1994 Yes Museum Specimen Crater Lake and ponds above, $5880 \mathrm{ft}$.

Meagher <.5 mile. 7/7/1994 No Museum Specimen Forest Lake, Crazy Mountains, also Sec. 35, $6490 \mathrm{ft}$.

Meagher <.5 mile. 7/8/1994 No Observation W. fork Checkerboard Creek, Castle Mountains, $6200 \mathrm{ft}$.

Meagher $\quad<.5$ mile. 7/9/1994 No Observation Onion Park, Little Belt Mountains, also sec. 5.

Meagher .5 to 5 mil 8/6/1958 No Museum Specimen Lake Creek

Meagher .5 to 5 mil 5/13/1950 No Museum Specimen Near Ringling Hot Well

Meagher .5 to 5 mil 8/6/1958 No Museum Specimen Lake Creek

Missoula .5 to 5 mil $5 / 18 / 1948$ No Observation Overflow of Union Creek, near McNamara

Missoula $<.5$ mile. $7 / 2 / 1993$ No Observation T16N R15W S25

Pondera <.5 mile. 7/6/1994 Yes Observation Kiyo Crag Lake and Pond, and sm. pond on RD 9218

Powell .5 to 5 mil 7/21/1891 No Museum Specimen Elliston, near Little Blackfoot River

\section{PAINTED TURTLE}

Broadwater <.5 mile. 5//1993 No Observation Canyon Ferry WMA east side.

Broadwater 5 to $10 \mathrm{mil} / \mathrm{/} 0$ No Specimen Reported See map in Black 1970

Lewis \& Clark <.5 mile. 6/9/1994 No Observation W. of Augusta along Benchmark Rd. W. of Nilan Reservoir, next to 2 ponds

Powell $\quad .5$ to 5 mil 9/7/1994 No Observation Lahrity Lake in Ovando Valley 
Montana Animal Atlas (Herpetile) Species Report

County Precision Date Breed Data Type

\section{PAINTED TURTLE (cont.)}

Powell .5 to 5 mil 9/8/1994 No Observation Evans Lake

Powell 5 to 10 mil / / 0 No Specimen Reported See map in Black 1970

Teton 5 to $10 \mathrm{mil} / / 0$ No Specimen Reported See map in Black, 1970

\section{SPINY SOFTSHELL}

Broadwater 5 to $10 \mathrm{mil} \mathrm{/} \mathrm{/} 0$ No Specimen Reported Canyon Ferry Reservoir (may be erroreous)

Wheatland .5 to $5 \mathrm{mil} / 17 / 1942$ No Museum Specimen Musselshell River, near Shawmut

Wheatland .5 to 5 mil / / 0 No Museum Specimen Musselshell River near Shawmut.

\section{SHORT HORNED LIZARD}

Chouteau >10 miles. / / 0 No Museum Specimen Near Fort Benton

Chouteau 5-10 miles spring 1985 No Observation Cascade Hutterite Colony west of Ulm in breaks, $3500 \mathrm{ft}$.

Golden Valley >10 miles. 8/ /1894 No Museum Specimen Painted Robe Creek

Toole >10 miles. / /1950 No Observation tops of ridges between coulees near camp (10 mi S of Galata)

Wheatland .5 to 5 mil $/ 29 / 1933$ No Museum Specimen Harlowton

\section{SAGEBRUSH LIZARD}

Mussellshell 5 to 10 mil 8/3/1908 No Museum Specimen Roundup, $8 \mathrm{mi}$ S of

\section{RUBBER BOA}

Broadwater 5 to 10 mil / / 0 No Specimen Reported See map in Davis 1963

Lewis \& Clark 5 to 10 mil / / 0 No Specimen Reported See map in Davis 1963

Lewis \& Clark .5 to 5 mil 3/ /1949 No Museum Specimen Worth Ranch, Canyon Creek 
Natural Heritage Program

03/04/1995

Montana Animal Atlas (Herpetile) Species Report

County Precision Date Breed Data Type

\section{RACER}

Flathead 5 to $10 \mathrm{mil} \mathrm{/} \mathrm{/} 0$ No Specimen Reported See map in Davis 1963

Lewis \& Clark 5 to 10 mil / / 0 No Specimen Reported See map in Davis 1963

Lewis \& Clark 5 to 10 mil / / 0 No Specimen Reported See map in Davis 1963

Lewis \& Clark 5 to 10 mil / / 0 No Specimen Reported See map in Davis 1963

Lewis \& Clark 5 to 10 mil / / 0 No Specimen Reported See map in Davis 1963

Lewis \& Clark 5 to $10 \mathrm{mil} \mathrm{/} \mathrm{/} 0$ No Specimen Reported See map in Davis 1963

Toole $\quad .5$ to 5 mil 7/26/1950 No Observation in a coulee just $\mathrm{N}$ of camp (10 mi S of Galata)

\section{WESTERN HOGNOSE SNAKE}

Mussellshell 5 to 10 mil / / 0 No Specimen Reported See map in Davis 1963

Teton 5 to $10 \mathrm{mil} \mathrm{/} \mathrm{/} 0$ No Specimen Reported See map in Davis 1963

\section{GOPHER SNAKE}

Broadwater <.5 mile. 5/21/1994 No Observation Hwy. 12 between Helena and Townsend

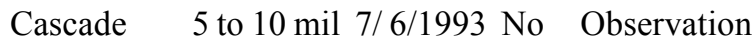
Chestnut Valley Sandhills

Cascade 5 to $10 \mathrm{mil} / / \quad 0$ No Specimen Reported See map in Davis 1963

Cascade $<.5$ miles 6/ /1994 No Observation near Belt Creek, T18N R6E Sec 12

Chouteau .5 to 5 mil / / 0 No Museum Specimen Fort Benton

Lewis \& Clark .5 to 5 mil 10/15/1982 No Museum Specimen Junction Sheep and Little Prickly Pear Creeks 
Natural Heritage Program

03/04/1995

Montana Animal Atlas (Herpetile) Species Report

County Precision Date Breed Data Type

GOPHER SNAKE (continued)

Toole $>10$ miles. / /1950 No Observation

9 from river valley, 1 from coulees, 2 from Prairie (approx. $10 \mathrm{mi} \mathrm{S}$ of Ga)

Wheatland .5 to $5 \mathrm{mil} / / 1932$ No Museum Specimen

Harlowton

Wheatland .5 to $5 \mathrm{mil} / / 0$ No Museum Specimen

20 miles E. of Harlowton

\section{WESTERN TERRESTRIAL GARTER SNAKE}

Broadwater .5 to 5 mil 9//1962 No Museum Specimen W. of Winston

Cascade $<.5$ mile. 5/28/1994 No Observation

Pond $0.5 \mathrm{mi} \mathrm{N}$. of Belt Creek Info Center on E. side of Hwy. 89

Cascade $\quad .5$ to 5 mil 10/15/1992 No Museum Specimen $5 \mathrm{mi}$. SE of Fairfield

Chouteau .5 to 5 mil / / 0 No Museum Specimen Fort Benton

Chouteau .5 to 5 mil 7/21/1962 No Museum Specimen Shankin Creek, Highwood Mountains

Chouteau .5 to 5 mil 5//1963 No Museum Specimen N. Fork Highwood Creek

Fergus $\quad .5$ to 5 mil 8/23/1954 No Museum Specimen 22 miles S., 12 miles E. of Lewiston

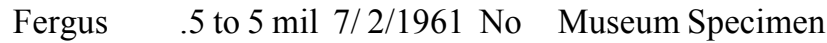
3 miles W., 18 miles S. of Lewiston, Big Snowy Mts.

Fergus $\quad .5$ to 5 mil 8/15/1918 No Museum Specimen Heath, $15 \mathrm{mi}$ S of, Big Snowy Mountains

Fergus $\quad 5$ to $10 \mathrm{mil} \mathrm{8/4/1919}$ No Museum Specimen Hilger, 5 mi NW of, Mocassin Mountains

Fergus 5 to 10 mil 7/27/1919 No Museum Specimen Hilger, $7 \mathrm{mi} \mathrm{NE}$ of

Fergus $\quad<.5$ mile. 7/7/1994 No Observation Crystal Lake, Big Snowy Mountains, $6000 \mathrm{ft}$. 


\title{
WESTERN TERRESTRIAL GARTER SNAKE (continued)
}

\author{
Gallatin 5 to $10 \mathrm{mil} / / 0$ No Specimen Reported \\ See map in Davis 1963 \\ Judith Basin .5 to 5 mil 8/7/1919 No Museum Specimen \\ Stanford, 20 SW of, Little Belt Mtns, on Dry Wolf Creek \\ Judith Basin . 5 to 5 mil 8/13/1919 No Museum Specimen \\ Geyser, Otter Creek, (10 mi SW) \\ Lewis \& Clark .5 to $5 \mathrm{mil} / / 0$ No Museum Specimen \\ Sun River at U.S. Hy 287, N of Augusta \\ Lewis \& Clark > 10 miles. 7/20/1891 No Museum Specimen \\ Helena, near, Mc Clellan Creek \\ Lewis \& Clark > 10 miles. 7/18/1958 No Museum Specimen \\ Sun River, elevation $5500 \mathrm{ft}$. \\ Lewis \& Clark <.5 mile. 5/27/1994 No Observation \\ Head of Little Willow Creek \\ Lewis \& Clark 5 to 10 mil / / 0 No Specimen Reported \\ See map in Davis 1963 \\ Lewis \& Clark $<.5$ mile. $7 / 27 / 1975$ No Observation \\ Pond, ca. $400 \mathrm{~m}$ from the main stack of East Helena Smelter. \\ Lewis \& Clark <.5 mile. 7/27/1975 No Observation \\ Where Prickly Pear Creek flows along slag pile at East Helena Smelter. \\ Lewis \& Clark $<.5$ mile. 7/27/1975 No Observation \\ McClellan Creek Quarry Lake \\ Liberty > 10 miles. 7/ /1950 No Observation \\ Liberty County about $6 \mathrm{mi}$.W of camp (approx. $10 \mathrm{mi}$. S of Galata) \\ Meagher .5 to 5 mil 9/4/1918 No Museum Specimen \\ Grovedale (Groveland), $3 \mathrm{mi} \mathrm{W}$ of \\ Meagher .5 to 5 mil 8/30/1918 No Museum Specimen \\ Martinsdale, S Fork of Musselshell River \\ Meagher 5 to $10 \mathrm{mil} 8 / 22 / 1919$ No Museum Specimen \\ Fort Logan, Camas Creek, (4 mi S)
}


Montana Animal Atlas (Herpetile) Species Report

County Precision Date Breed Data Type

WESTERN TERRESTRIAL GARTER SNAKE (continued)

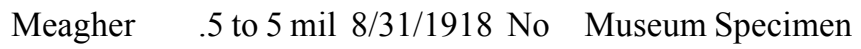
Martinsdale, $\mathrm{S}$ fork of Musselshell River

Missoula $<.5$ mile. 7/ 1/1993 No Observation

Grassy hillside, $100 \mathrm{~m}$ from riparian area Clearwater River

Missoula <.5 mile. 9/ /1950 No Specimen Reported Upper Holland Lake

Missoula <.5 mile. 9/ /1950 No Specimen Reported Gyp Mountain

Powell > $>10$ miles. 7/31/1967 No Museum Specimen North Fork of the Blackfoot River

Powell >10 miles. 7/3/1973 No Museum Specimen North Fork of the Blackfoot River

Powell <.5 mile. 6/ /1950 No Specimen Reported Cottonwood Creek

Teton $\quad .5$ to 5 mil 10/16/1982 No Museum Specimen $10 \mathrm{mi}$. W. of Chouteau

\section{PLAINS GARTER SNAKE}

Cascade $\quad .5$ to 5 mil 8/31/1894 No Museum Specimen Great Falls

Chouteau .5 to 5 mil / / 0 No Museum Specimen Fort Benton

Toole $\quad .5$ to 5 mil 7/16/1950 No Observation margin of cattle pond $1.5 \mathrm{mi} \mathrm{S}$ of camp $(10 \mathrm{mi} \mathrm{S}$ 0f Galata

\section{COMMON GARTER SNAKE}

Carbon $\quad .5$ to $5 \mathrm{mil} / / 0$ No Museum Specimen Fort Benton

Cascade $\quad .5$ to 5 mil 9/6/1994 No Observation Schrammeck Lake

Chouteau .5 to 5 mil 6/24/1962 No Museum Specimen Upper Highwood Creek near pass to Arrow Creek 
Montana Animal Atlas (Herpetile) Species Report

County Precision Date Breed Data Type

COMMON GARTER SNAKE (continued)

Fergus $\quad .5$ to 5 mil 8/16/1918 No Museum Specimen 1 mile SE of Lewistown

Golden Valley .5 to 5 mil 10/10/1994 No Observation Near Big Coulee Creek

Judith Basin <.5 mile. 5/20/1994 No Observation Along tributary to Dry Pole Gulch.

Lewis \& Clark <.5 mile. 5/27/1994 No Observation Willow Creek Ponds, $5540 \mathrm{ft}$.

Lewis \& Clark $<.5$ mile. 5/5/1994 No Observation Smith Creek

Lewis \& Clark 5 to 10 mil / / 0 No Specimen Reported See map in Davis 1963

Lewis \& Clark 5 to 10 mil / / 0 No Specimen Reported See map in Davis 1963

Missoula $<.5$ mile. 7/2/1993 No Observation NW1/4 of SE1/4 Sec25, $10 \mathrm{~m}$ from water.

Teton <.5 mile. 7/5/1993 No Observation Durr Place, outside tack room, Pine Butte Swamp Preserve

\section{WESTERN RATTLESNAKE}

Cascade $\quad 5$ to 10 mil 9/1/1894 No Museum Specimen Great Falls

Cascade $\quad .5$ to 5 mil $/ 10 / 1937$ No Museum Specimen 7 miles NW of Cascade

Cascade .5 to 5 mil 7/29/1972 No Museum Specimen $3 \mathrm{mi}$. N. Manchester

Cascade $\quad .5$ to 5 mil / /1927 No Museum Specimen Cascade

Chouteau .5 to 5 mil 10//1937 No Museum Specimen 30 miles east of Brady, 2 miles south of Russell

Chouteau .5 to 5 mil / / 0 No Museum Specimen Ft. Benton 
Natural Heritage Program

03/04/1995

Montana Animal Atlas (Herpetile) Species Report

County Precision Date Breed Data Type

WESTERN RATTLESNAKE (continued)

Fergus $\quad .5$ to 5 mil 7/24/1919 No Museum Specimen

5 miles north of Wilder on Missouri River

Gallatin 5 to $10 \mathrm{mil} / / 0$ No Specimen Reported

See map in Davis 1963

Lewis \& Clark .5 to 5 mil 7/28/1949 No Museum Specimen

Wirth Ranch

Liberty $<.5$ mile. 7/6/1994 No Observation

5.3 mi. E. of Tiber Dam on Prospect Road, 3030 ft., also sec. 10.

Mussellshell 5 to 10 mil / / 0 No Specimen Reported See map in Davis 1963

Toole $>10$ miles. 7/24/1950 No Observation

Marias river near camp (10 mi south of Galata)

Wheatland .5 to 5 mil / / 0 No Museum Specimen Harlowton

Wheatland .5 to 5 mil / / 0 No Museum Specimen 2 miles S. of Hedgesville, 20 miles E. of Harlowton

Wheatland >10 miles. 8/12/1903 No Museum Specimen vic of Harlowton

Wheatland >10 miles. 4/16/1967 No Museum Specimen vic Harlowton

Wheatland >10 miles. 5/11/1984 No Museum Specimen vic of Harlowton

Wheatland <.5 mile. / /1989 No Observation

Behind USFS office, Harlowton

Wheatland .5 to 5 mil $/ 24 / 1932$ No Museum Specimen

8 miles S. of Harlowton

Wheatland .5 to 5 mil $/ 29 / 1932$ No Museum Specimen

8 miles S. of Harlowton

Wheatland .5 to 5 mil $/ 22 / 1933$ No Museum Specimen

2 miles S Hedgesville 
Natural Heritage Program

03/04/1995

Montana Animal Atlas (Herpetile) Species Report

County Precision Date Breed Data Type

WESTERN RATTLESNAKE (continued)

Wheatland .5 to 5 mil / /1935 No Museum Specimen

8 miles S. of Harlowton

Wheatland .5 to 5 mil / /1932 No Museum Specimen 2 miles S Hedgeville

Wheatland .5 to 5 mil $/ 24 / 1926$ No Museum Specimen 8 miles S. of Harlowton

Yellowstone 5 to $10 \mathrm{mil} / / 0$ No Specimen Reported See map in Davis 1963 